\title{
Sugar and Democracy in Fiji: The material foundations of post-colonial authoritarianism 1970-2005
}

By

Keiran Barbalich

\author{
A Thesis \\ submitted to the Victoria University of Wellington \\ in fulfilment of the requirements for the \\ Degree of Masters of Arts \\ in Political Science
}

School of History, Philosophy, Political Science \& International Relations

Victoria University of Wellington

2009 


\begin{abstract}
Fiji became independent in 1970, and functioned for 17 years under a constitution with democratic elements, including elections. Three times since 1987, however, armed force has overthrown constitutionally elected governments. Some observers see this as a failure of the consolidation of Fijian democracy, while others acknowledge the façade of Fijian democracy. Among those who acknowledge Fijiss authoritarian institutions, conflict persists as to whether authoritarianism is the inevitable product of ethnic conflict in Fijian society, or a consequence of post-colonial institutional legacies. No movement toward democracy in Fiji is likely to succeed until we understand the material foundations underlying Fiji's authoritarian politics.
\end{abstract}

This thesis argues that Fiji's authoritarian political institutions, established under colonial rule, have been sustained since independence by forces in the international economy. These forces have helped to maintain the economic, social and political dominance of a PacificFijian chiefly elite over Fijian society. Specially, chiefly control of the sugar industry, Fiji's principal export, has provided chiefs with sufficient patronage resources to retain their control over Fijian society through electoral politics or, at the event of undesirable electoral outcomes, through armed opposition. Through post-colonial structures, the chiefs control the land-tenure system, and through their setting and receipt of land rents, they have been the principal beneficiaries of Fiji's sugar exports. This comparatively inefficient industry, and the social and political institutions that it rests on, have survived because Fiji, as party to the European Union's Sugar Protocol, has received two-and-a-half to three times the world market price for its sugar exports between 1975 and 2009.

This thesis makes its case through close textual analysis of Fijis three constitutions, detailed inspection of Fiji's land-tenure system, and, specifically, the accounts of the Native Land Trust Board, as well as examination of the secondary literature on Fiji's sugar industry. 


\section{Acknowledgements}

I would like to gratefully acknowledge the support I have had from an assortment of people and organisations without which this thesis would not have been possible.

First and foremost, I must give my utmost thanks and appreciation to my primary supervisor Dr John Leslie. John has supported and encouraged me throughout this process, from its inception as a loose honours research paper, to its development into this thesis. John, thank you for being open with me when my work was not refined enough, for your patience while the thesis approached the necessary standard, and for your commitment to this me and this work throughout the past 15 months. Thanks is also due to my secondary supervisor Dr. Roderic Alley. Rod your support and flexibility was invaluable in overseeing this work.

I wish to thank a group of peers and close friends who without their support and critical feedback this thesis would not exist. First, Shaun McGirr. Not only was Shaun a sounding board for all key ideas of this thesis, but he has also been my hardest critic and I thank you for caring to put so much time into assisting me with this work.

Special thanks also goes to those who debated pieces of my thesis over and over when me when we were both adamant each of us was right. To those who tutored and taught me, read drafts for me and assisted the rewriting process. Special mention here goes to Ara Tai Rākena, Robert Addison, Matt Davis, Pala Molisa, David Carter and Wayne Pihema.

And a special thanks to all my political, apolitical or non-political friends who kept interested in my study, and kept in contact despite my inability to do the same for them at time. Thanks for keeping in close contact and keeping me down to earth.

I am also grateful to a number of institutions, for without their generosity this research would have been severely limited. First, the European Union Centre's Network, for providing me with not only with scholarship for thesis course fees, but also funding to attend and present my research at its 2007 and 2008 annual conferences, and 2008 and 2009 graduate retreats. Second, Victoria University of Wellington for providing funding for my fieldwork to Fiji and for funding to attend and present my research at the Australian Political Science 2008 conference held in Brisbane. Third, the Pacific Islands Political Science association, which funded my attendance to present research at its 2007 conference in Port Vila, Vanuatu. These opportunities enabled me not only test various claims of my research but to steer in down its most fruitful path.

I also wish to thank the members of the Political Science \& International Relations Programme at Victoria University who have supported and encouraged me with in my formulation of this thesis. I wish to specially thank Dr Christopher LaMonica for making political science seem real for me and for whilst I was an undergraduate at Victoria. Without Chris' inspiration, to path of postgraduate study would never have crossed my mind. A special thanks also to Professor Elizabeth McLeay for the support she provided to myself and thesis postgraduates within the department.

Thanks is due to all those at the University of the South Pacific, Suva, who made my fieldwork all the easier. Special mention goes to Dr Rae Nicholl for the time she invested in ensuring my time in Suva went smoothly. To the photocopier at the USP library many 
thanks for the many boxes of photocopying you did for me. To Ruth and Neil Lund for providing me accommodation for the majority of my stay in Suva.

Special thanks to those who provided me employment during my tenure writing this thesis. To those who I tutored for within the Political Science \& International Relations Programme, notably, Dr David Capie, Dr Annmarie Elijah, and Dr Pat Maloney. To Tina McNicholas at the Pacific Cooperation Foundation, and Sharon Jones at the New Zealand Education Institute. These people made my workload outside university very manageable, especially under the stresses of fundraising for the field trip.

Special mention must be made of my fellow students, particularly Kelvin Bannan, Rupert Mackintosh, Jason Young, Helena Cook and the many others who's company, and support made this process much more enjoyable.

Last but most of all, I would like my parents Anne-Marie and Nick Barbalich, and my brothers Rowan and Gerard. Thank you so much for constantly giving me love and support, as well as providing eyes, ears and edits to help me complete this thesis.

To Alyce Butler, I realise you have learnt more about the political economy of Fiji than you probably have ever wanted to, however, was still willing to have the same conversation with me over and over again to reassure me, when I was adamant I was missing something out. For this, I thank you. This thesis could not have been completed without your love, patience, and occasional harassment. 


\section{Table of Contents}

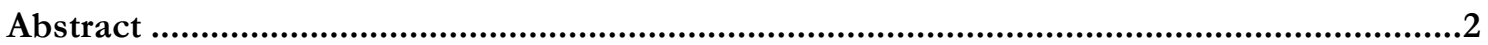

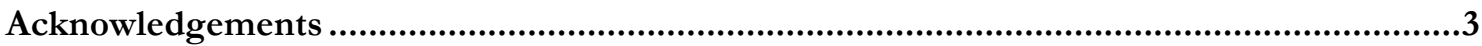

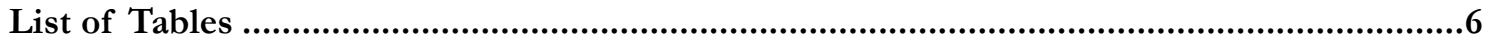

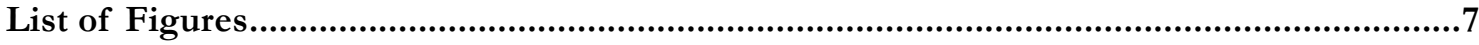

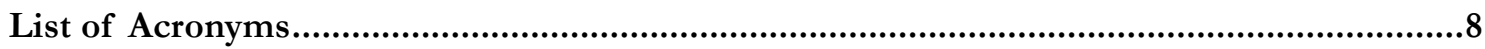

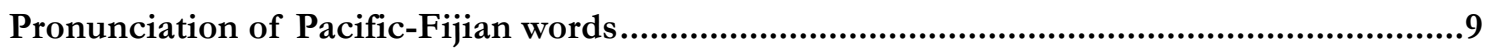

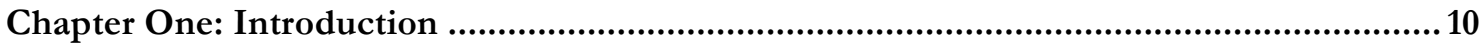

Chapter Two: Democratisation, Ethnic Conflict and the International Political Economy:

Interdependence of Domestic Structures in the International Context ................................13

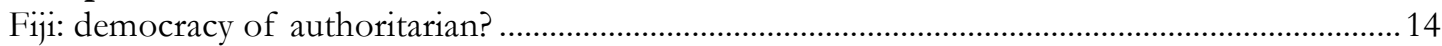

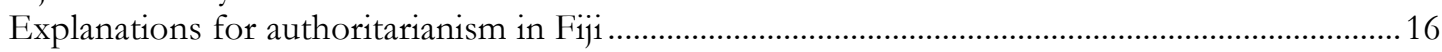

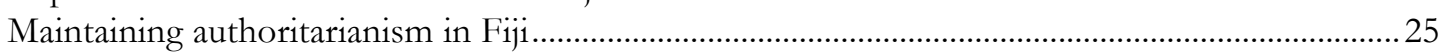

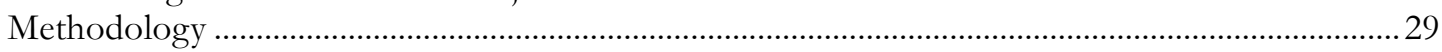

Chapter Three: Fiji's Parallel Authority Structures .................................................................34

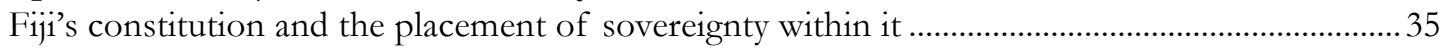

How an authoritarian chiefly elite governs the economy ……………………………….................... 43

Chapter Four: Independence and the Resurgence of Authoritarianism 1970 -1990 ..............72

The first Fijian elections 1970-1977 ............................................................................................... 73

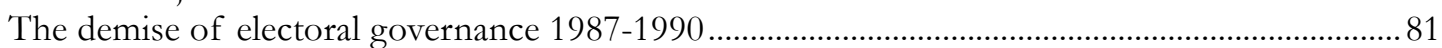

Chapter Five: Divided Authoritarianism 1990-2005 …........................................................94

The reassertion of Pacific-Fijian nationalism 2000-2005 ……………………………………….......104

Chapter Six: Conclusion...............................................................................................116

Appendix 1: Raw sugar produced per sugar industry employee, selected developing countries ....121

Appendix 2: Expiry numbers of ALTA sugarcane leases held by Indo-Fijians due to expire in Fiji

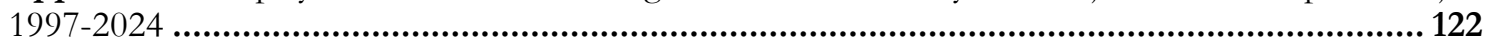

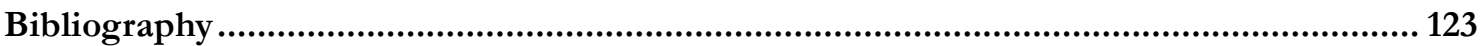




\section{List of Tables}

Table 1: Composition of the electoral seats in the House of Representatives across Fijis 1970, 1990 and 1997 Constitutions

Table 2: Composition of the Senate across Fiji’s 1970, 1990 and 1997 Constitutions ..........39

Table 3: The differences between ALTA and NLTA lease agreements ...................................75

Table 4: 1990 Constitution distribution of electoral seats amongst Fiji's ethnic communities

Table 5: 1990 Constitution distribution of Pacific-Fijian communal seats amongst regional

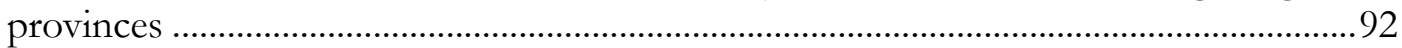

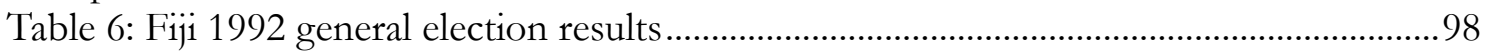

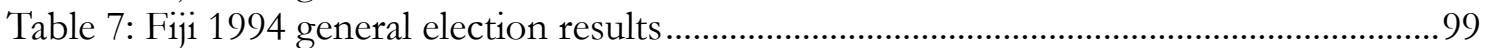

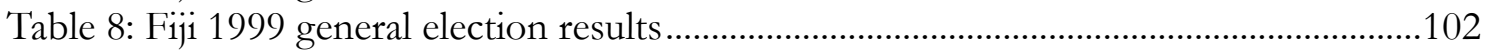

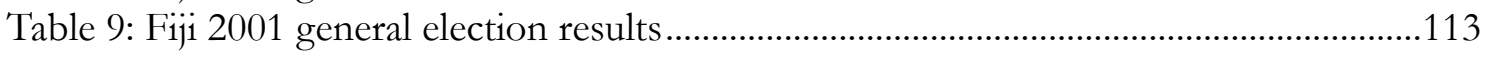




\section{List of Figures}

Figure 1: Maxwell's Depiction of Fiji's Pre-Colonial Social Structure ....................................47

Figure 2: Rent Per Hectare for Agricultural Lease Agreements in Fiji Across Ethnic Groups in 1990 .54

Figure 3: Tiered Distribution of Native Land Lease Rents.. 


\section{List of Acronyms}

ACP - African, Caribbean \& Pacific (bloc of) countries

ALTA - Agricultural Landlord and Tenant Act 1976

ALTO - Agricultural Landlord and Tenant Ordinance 1966

CAMV - Conservative Alliance-Matanitu Vanua Party

CAP - (European Union's) Common Agricultural Policy

CRWU - Counter Revolutionary Warfare Unit

EEC - European Economic Community (1957-1986)

EPA - Economic Partnership Agreement

EU - European Union (1994-)

FNUF - Fijian National United Front

FRMF - Fijian Royal Military Forces (prior to the declaration of a republic in October 1987)

FSC - Fijian Sugar Corporation

GVP - General Voters Party

MPs - Members of the Fijian Parliament (House Representatives)

NLTA - Native Land Trust Act 1970

NLTB - Native Land Trust Board

NLTO - Native Land Trust Ordinance 1940

PANU - Party of National Unity

RFMF - Republic of Fiji Military Force (after the declaration of a republic in October 1987)

SDL - Soqosoqo Duavata ni Lewenivanua Party

SPS - Special Preferential Sugar

SVT - Soqosoqo ni Vakavulewa ni Taukei Party

UCV - Unimproved Capital Value 


\section{Pronunciation of Pacific-Fijian words}

Readers unfamiliar with Pacific-Fijian pronunciation should note the following consonant sounds:

$\mathrm{B}$ is pronounced "mb" e.g. Bau (Mbau)

C is pronounced "th" e.g. Colo West (Tholo West)

$\mathrm{D}$ is pronounced "nd" e.g. Nadi (Nandi)

$G$ is pronounced "ng" e.g. Nadroga (Nandromga)

$\mathrm{Q}$ is pronounced " $\mathrm{g}$ " as in "gung" when beginning a word, and " $\mathrm{n} . . . \mathrm{g}$ " when within a word in mataqali and yaqona: "matan...gali" and "yan...gona" 


\section{Chapter One: Introduction}

Fiji's experience with democracy has been troubled. Elected government arrived in Fiji in with its independence from Britain in 1970. Initially its constitutional design seemed democratic. Since that time, however, elected government has been deposed by armed force three times - in 1987, 2000 and 2006. To some observers this demonstrates that Fiji's democracy failed to consolidate. Each overthrow of government has come when an elected government threatened to disrupt the traditional authorities' control of the economy and society. In the face of that threat traditional authorities have used extra constitutional means to replace elected government, with an alternative aligned with their interests. The unwillingness of traditional authorities to permit a transition of government since independence poses the question as to whether Fiji ever was a democracy.

Some observers acknowledge that Fiji was never democratic, offering contending explanations for the persistence of traditional authoritarian rule. Analysts close to traditional Fijian elites explain the persistence of authoritarian behaviour a necessary to maintain order in a society riven by ethnic conflict. Critics of Fiji's traditional social hierarchy see this relationship reversed, that is, chiefly elites aggravate ethnic divisions to maintain their position at the top of Fijian society and politics. Both sides, however, cannot explain why ethnic divisions and social hierarchy have persistently prevented democratisation in Fiji, when they have not necessarily done so elsewhere. In other former British colonies, entrenched social hierarchies and ethnic divisions have not prevented democratic government, including alternations in power. Why has Fiji been unable to manage ethnic conflict and transcend traditional hierarchy?

This thesis contends that the persistence of authoritarianism in Fiji has other roots. A traditional elite of Pacific-Fijian chiefs has maintained its place in Fiji's social order through its control of the critical factor of production, land. Land is crucial to Fiji's two largest industries, tourism and sugar. Control of these resources provides chiefs with extensive resources of patronage, to hold their place in society.

This thesis focuses on the role of sugar in this process, although developments in the tourist industry are similar. 
The sugar industry links Fiji to the world economy. The Fijian sugar industry, however, has been able to avoid the competitive pressures of world markets. As a party to the European Union's (EU) Sugar Protocol and a recipient of EU sugar subsidies, Fijian sugar producers receive two-and-a-half to three times world market prices for their sugar. These subsidies permit chiefs to inflate lease rents. Inflated rents provide chiefs the material means to maintain patronage networks and their control of Fijian society and politics.

The remainder of this thesis proceeds in five chapters. The second chapter examines and places the argument of this thesis in the context of existing explanations of Fiji's political development after independence. It critically examines assertions that Fiji possesses democratic institutions that have failed to consolidate. It also refutes arguments that claim authoritarianism is a necessary response to ethnic conflict in Fiji. It examines arguments about the persistence of Fiji's social oligarchy. Where these arguments simply assert the persistence of colonial institutions after independence - without an explanation for why this should be - this thesis holds that their persistence reflects Fiji's position in the international economic order. This chapter also introduces the framework for investigation of the thesis and addresses the constraints under which the research was undertaken.

The third chapter introduces the contending constitutional and traditional structures of political authority. It outlines the provisions for elected legislative and executive power in the 1970, 1990 and 1997 Constitutions. It also demonstrates how each of those constitutions reserved decision-making authority on critical issue areas, specifically land tenure, for unelected representatives of the chiefly social hierarchy. Finally it delineates the structure of land tenure and sugar production, as well as how these serve to maintain chiefly control of Fijian society and politics.

Chapters Four and Five test the thesis' hypotheses. Chapter Four examines motivations of political actors in the 1977 and 1987 general elections, and the chiefs' responses to a possible change in government. In 1977, the chiefs were at best ambivalent about the constitution, yet found constitutional means to prevent a transition in government. In 1987, chiefs simply dismissed the constitution and overthrew an elected government.

Chapter Five examines the 1999 general election, the coups that followed in its wake, and 
their aftermath. Once again, an election brought a change in government away from chiefly-backed parties. This chapter illustrates the involvement of high chiefs in the May 2000 overthrow.

The concluding chapter reflects on the why chiefs were unwilling to surrender political authority to elected government. It also contemplates the growing divisions amongst chiefs, as became increasingly evident after the promulgation of the 1990 Constitution. The divisions amongst the Pacific-Fijian chiefly elites have made it impossible for this elite to maintain their authority in Fijian society and politics. Finally, the conclusion considers the coup of December 2006 in the context of the erosion of solidarity amongst Pacific-Fijian elites, and reflects on the thesis' implications for cases akin to Fiji. 


\section{Chapter Two: Democratisation, Ethnic Conflict and the International Political Economy: Interdependence of Domestic Structures in the International Context}

Accounts of Fiji's political development since independence have been dominated by two partially conflicting categories of explanation. Many observers suggest that Fiji has been moving toward democratic consolidation on a path interrupted by unfortunate circumstances. Others suggest that the sources of Fiji's democratic failings are home grown, rising out of divisions within Fijian society. ${ }^{1}$ There are good reasons, however, to question whether since independence Fiji has ever been on the road to democratic consolidation or whether the forces restricting democratic development in Fiji are primarily, or even purely, domestic.

The argument of this thesis turns extant explanations of the causes of Fiji's troubled experience with democracy on their head. First, it argues Fiji has never been moving toward democratic consolidation. An authoritarian political-economic structure was established prior to independence and has maintained itself since. Second, neither ethnic nor class divisions in Fijian society are cause of the failure of Fiji's democratic institutions to consolidate. Rather, consolidation of these institutions was never permissible, as Fiji's political system has always been authoritarian, despite the presence of electoral institutions that have made it appear democratic. Finally, it is Fijis place in the world economy that permits the maintenance of Fiji's illiberal institutional structures, which in turn permit the repetition of authoritarian behaviour.

This chapter develops this argument in three sections. First, it considers arguments that see Fijian history as one of 'interrupted' or 'unconsolidated' democratic development. Second, it considers arguments that hold divisions in Fijian society - ethnic and socio-economic responsible for Fiji's democratic failings. Finally, it demonstrates how Fiji's experience fits into a wider literature that relates internal political developments to a society's position in the international economy. It examines classic theoretical approaches that explain sources of crisis within domestic politics, and the centre of this conflict in relation to the political systems it operates within.

\footnotetext{
${ }^{1}$ I use this term to refer to any peoples living in Fiji, or holding citizenship of Fiji.
} 


\section{Fiji: democracy of authoritarian?}

Extant explanations diagnose the failings of Fiji's democracy by focusing exclusively on the phenomena that have interrupted its democratic consolidation. ${ }^{2}$ In doing this they have failed to capture the post-colonial reality of Fiji's political system. These explanations have examined the anti-democratic social forces that have caused the interruption of democratic rule, which are presented as ethnic and socio-economic tensions. In doing so, they have depended on an assumption that Fiji's post-colonial institutions were democratic at the outset. Therefore, Fiji's constitutional provisions must be examined to determine whether democracy ever existed.

To assess whether Fiji ever was a democracy, a suitable definition is needed. The literature on democracy and the character of democratic institutions is vast and varied, ${ }^{3}$ however, Schumpeter provides a useful definition as a minimal standard of democracy. Schumpeter outlines a clear definition of the democratic process, as "that institutional arrangement for arriving at political decisions in which individuals acquire the power to decide by means of a competitive struggle for the people's vote."4 This definition encompasses two elements: the presence of a competitive struggle for power in elections, and that the competitive process determines the composition of decision-making institutions that are not interfered with in their implementation of policy. Building further on this, Przeworski defines democracy as a system in which "Outcomes... are uncertain, indeterminate ex ante; and it is 'the people,' and political forces competing to promote their interests and values, who determine what these outcomes will be." 5 This definition comprises the necessity of the presence of contestation and uncertainty in the electoral system, and the ability of elected office holders to translate their policy, uninhibited, to reform.

\footnotetext{
2 Przeworksi notes that even if a democracy is established it need not be consolidated. Rather a democracy is consolidated when most conflicts are processed through democratic institutions, when nobody can control the outcomes ex post and the results are not predetermined ex ante, they matter within some predictable limits, and they evoke the compliance of relevant political forces. Adam Przeworksi, Democracy and the Market: Political and Economic Reforms in Eastern Europe and Latin America, ed. Jon Elster and Michael S. McPherson, Studies in Rationality and Social Change (Cambridge: Cambridge University Press, 1991), p. 51.

3 David Collier and Stephen Levitsky, "Democracy with Adjectives: Conceptual Innovation in Comparative Research," World Politics 49, no. 3 (1997).

${ }^{4}$ Joseph A. Schumpeter, Capitalism, Socialism and Democracy, 2nd ed. (New York and London: Harper \& Brothers Publishers, 1942), p. 269.

${ }^{5}$ Przeworksi, Democracy and the Market: Political and Economic Reforms in Eastern Europe and Latin America, p. 10.
} 
Fiji fails to meet Schumpeter and Przeworski's minimum standards of democratic political institutions. Sovereignty is embedded in decision-making institutions, only some of which are electorally accountable. Although electoral processes determine the composition of the lower house of the legislature, the upper house is unelected. But most importantly, those Senators nominated by an unelected authority, the Council of Chiefs, ${ }^{6}$ hold an effective veto over any reform of the land-tenure system. This means that critical features of the Fijian economy, land tenure and the distribution of rents, have been removed from the purview of democratic decision-making, and preserved for a chiefly elite. Decision-making across these policy arenas is not, and never has been, democratically accountable. In failing Schumpeter and Przeworski's minimal definitions of democratic government, Fiji fails the test in all classic definitions of democratisation literature. ${ }^{7}$

Some arguments hold that, but for the lack of a set of particular electoral institutions, Fijian democracy would be successful. These scholars argue that merely the application of the most appropriate electoral system is sufficient to provide democratic consolidation. ${ }^{8}$ These debates, however, overlook the authoritarian reality embedded in each of Fiji's three constitutions, and, therefore, fail to diagnose the underlying problem of Fijian democracy.

Since the 1987 coup and the 1990 constitutional reform, rigorous academic debate has focused on Fiji as a test tube for the effectiveness of differing electoral systems in providing sustainable democratic outcomes. The aim of this debate is to provide electoral stability by maximising the legitimacy of electoral institutions, while ensuring outcomes are still proportionate to the ethnic demographics of the population. Electoral constituencies have been gerrymandered and electoral mechanisms tailored to provide these outcomes.

Reflecting on the Fijis 1999 and 2001 election results and the intervening putsch, Horowitz debated with Fraenkel and Grofman the virtues of the electoral systems in providing stability and legitimacy to electoral outcomes. ${ }^{9}$ Horowitz advocated the use of an

\footnotetext{
${ }^{6}$ Although colloquially known as the 'Great Council of Cheifs' its formal title is simply the 'Council of Chiefs'. I will use the formal title. Bose Levu Vakaturaga is the formal Pacific-Fijian title.

${ }^{7}$ Robert A. Dahl, After the Revolution? Authority in a Good Society (New Haven and London: Yale University Press, 1970), p. 78.; - Polyarchy: Participation and Opposition (New Haven and London: Yale University Press, 1971), pp. 150-62.; Seymour Martin Lipset, Political Man: The Social Bases of Politics, Expanded and Updated edition ed. (Baltimore, Maryland: John Hopkins Universtiy Press, 1981), p. 27.; Samuel P. Huntington, The Third Wave: Democratization in the Late Twentieth Century (Oklahoma: University of Oklahoma Press, 1993), pp. 5-11.

${ }^{8}$ Rein Taagepera, "How Electoral Systems Matter for Democratization," Democratization 5, no. 3 (1998).

9 Two exchanges have been published. The first in Public Choice 121, December 2004, the second in
} 
alternative vote electoral system because, even under adverse social conditions, he argued that they provided moderate electoral results that facilitate cross-ethnic cooperation. ${ }^{10}$ Fraenkel and Grofman contest the success of alternative vote, citing its record in Fiji where, electoral results have skewed margins of victory, undermining the legitimacy of electoral institutions in the eyes of the populous. They promote instead the adoption of a proportional representation electoral system. ${ }^{11}$

Despite different electoral systems under all three constitutions, the mitigation of ethnic antagonism is not the principal cause of Fiji's failed democracy. At each re-design, the electoral system has only ever elected the lower house of the legislature, whilst the upper house has remained appointed by political elites. Importantly the Council of Chiefs' appointees to the Senate have veto over specified legislation, limiting the influence of elected political actors to reform legislation. The veto power given to an unelected institution's nominees in the Senate undermines Fiji's democratic status. At best what these proponents of electoral engineering see in Fiji is an illiberal democracy. ${ }^{12}$ In light of the control this authoritarian institution possesses over the land-tenure system, which is the most pivotal feature of Fiji's economy, the academic debates over electoral reform argue past the Fiji's post-colonial reality.

\section{Explanations for authoritarianism in Fiji}

Two types of explanation - one based on the role of ethnic divisions and the other based on socio-economic hierarchy - ignore debate about democratic consolidation to focus on the authoritarian nature of the Fijian polity. Both categories of explanation offer insight

Comparative Political Studies, Vol. 39, No. 5, June 2006.

${ }^{10}$ Donald L. Horowitz, "The Alternative Vote and Interethnic Moderation: A Reply to Fraenkel and Grofman," Public Choice 121 (2004).; __ , "Strategy Takes a Holiday: Fraenkel and Grofman on the Alternative Vote," Comparative Political Studies 39, no. 5 (2006).; —_, "Encouraging Electoral

Accommodation in Divided Societies," in Electoral Systems in Divided Societies: The Fiji Constitution Review, ed. Brij V. Lal and P. Larmour (Canberra: The Australian National University Press, 1997).

11 Jon Fraenkel and Bernard B. Grofman, "A Neo-Downsian Model of the Alternative Vote as a Mechanism for Mitigating Conflict in Plural Societies," Public Choice 121 (2004).; —_, "Does the Alternative Vote Foster Moderation in Ethnically Divided Societies? The Case of Fiji," Comparative Political Studies 39, no. 5 (2006).; _ , "The Failure of Alternative Vote as a Tool for Ethnic Moderation in Fiji: A Rejoinder to Horowitz," Comparative Political Studies 39, no. 5 (2006).; Jon Fraenkel, "The Alternative Vote System in Fiji: Electoral Engineering or Ballot-Rigging?," Journal of Commonwealth and Comparative Politics 39, no. 1 (2001).; —, "The Failure of Electoral Engineering in Fiji," Peace Initiatives 6, no. 1-3 (2000).; —_, "The Triumph of Non-Idealist Intellectuals? An Investigation of Fiji's 1999 Election Results," Australian Journal of Politics and History 46, no. 1 (2000).

12 Fareed Zakaria, "The Rise of Illiberal Democracy," Foreign Affairs 76, no. 6 (1997). 
into the dominance the chiefly elite has possessed over electoral institutions in Fiji. They both, however, offer incomplete explanations as to the means through which this elite has usurped electoral institutions. They fail to detail the role of Fiji's peculiar economic institutions and its position in the world economy in providing the chiefly elite material dominance over society.

The distribution of sovereignty across Fiji's constitutional institutions, over which an unelected institution has held veto power, has undermined electoral institutions status as democratic institutions. Those who hold ethnic divisions responsible for the failure of Fiji's democracy, in detailing excuses for the overthrow of electoral results, acknowledge the absence of democracy in post-colonial Fiji. They hold that democracy is incompatible with Fiji's traditional hierarchy, which holds more cultural legitimacy among Pacific-Fijians ${ }^{13}$ than imposed Western liberal democracy. For these scholars the need to maintain tradition escalates this conflict. Others hold historical class differences within Fijian society responsible for the failure of Fiji's democracy. They demonstrate how chiefly elites exploit ethnic antagonism and utilise their material privilege to bypass undesirable electoral outcomes to maintain authoritarian control of society.

This section examines how these two schools of thought have approached the problem of Fijian authoritarianism. First, it addresses those perspectives that hold ethnic divisions exacerbate political conflicts, making democratic governance untenable. Second, it examines the contributions of those proponents of class-based explanations of the polity, and the relationship they draw between elite and non-elites in undermining electoral institutions.

\section{Ethnic divisions and the maintenance of social hierarchy}

\footnotetext{
13 In referring to the two largest ethnic groupings in Fiji I use labels "Pacific-Fijians" and "Indo-Fijians", which serve both to identify their current place of residence and ethnic heritage. These labels are to ensure objectivity to the description of each ethnic grouping. Commonly "Pacific-Fijians" are referred to as either "indigenous Fijians" or simply "Fijians". Both of these terms are problematic as they convey heritage and ownership, one in an historical sense and one in the moment. In Fiji, such a high proportion of land (87\%) is exclusively reserved for one ethnic group, and this is so highly politicized, ethnic labels with connotations of ownership are not useful. Historically "Pacific-Fijians" have referred to themselves in their tongue as "Taukei". Taukei, in colonial and post-colonial Fiji is "Pacific-Fijian" for a member of a land-owning clan. Pre-colonialism, where land was not 'owned' this term naturally extended to all "Pacific-Fijians." I have not used the this term, however, as within post-colonial Fiji it brings strong associations with Pacific-Fijian nationalist phenomena, which have commonly labelled their causes and movements as Taukei. The politicisation of this word makes it unusable whilst seeking objective analysis.
} 
Most of those who hold ethnicity as the cause of Fiji's failed democracy acknowledge the realities of Fiji's three constitutions, and importantly the absence of democracy in them. ${ }^{14}$ They argue that racial ${ }^{15}$ divisions and the paramountcy of Pacific-Fijian traditions make democracy impossible and, that therefore, authoritarianism is the only way to prevent ongoing civil conflict. Further, they excuse the incompatibility of democratic governance with the conflict between Fiji's Pacific-Fijian and Indo-Fijian communities. They suggest arrangements where electoral representation can exist, but in a subordinate relationship to rule by chiefly elites. Bole and Ravuvu hold that authoritarianism must be entrenched before the anyway sovereignty can be transferred back to the populous in determining the governance of Fiji. Their proposed order is backward in its understanding of the power structures underlying Fiji's polity.

Proponents of the role of tradition in Fijian politics outright reject the viability of an IndoFijian government. They argue that Indo-Fijian controlled government is illegitimate, due to an apparent need for Pacific-Fijian chiefly paramountcy. In doing so, they point to the inevitability of the overthrows. ${ }^{16}$ Dean and Ritova present an racially focused commentary justifying Rabuka's 1987 overthrow, asserting that Fiji should be exclusively run by PacificFijians, irrespective of whether electoral institutions provide for this or not. ${ }^{17}$ In defending authoritarianism, Bole argues that the rise of modern democracies has been associated with instability, political conflagration and violence. He states that in the case of Fiji, the chiefly system has played a vital role in minimising the impact of destabilising contradictions

${ }^{14}$ Filipe N. Bole, "Fiji's Chiefly System and Its Pattern of Political Self-Reliance," in Culture and Democracy in the South Pacific, ed. Ron Crocombe, et al. (Suva: Institute of Pacific Studies, University of the South Pacific, 1992).; Eddie Dean and Stan Ritova, Rabuka: No Other Way (Moorebank, New South Wales: Doubleday, 1988).; Asesela Ravuvu, The Facade of Democracy: Fijian Struggles for Political Control 1830-1987 (Suva: Reader Publishing House, 1991).; __ , "The Fijian Chiefly System and the Democratic Process," (Suva: Pacific Cultural Programme, 1991), __ , "Culture and Traditions: Implications for Modern Nation Building," in Culture and Democracy in the South Pacific, ed. Ron Crocombe, et al. (Suva: Institute of Pacific Studies, University of the South Pacific, 1992).; Deryck Scarr, Fiji: Politics of Illusion, the Military Coups in Fiji (Kensington, New South Wales: New South Wales University Press, 1988).

15 Observations of ethnic phenomena are often characterised exclusively as racial, and observations of socioeconomic difference are characterised exclusively as class. These labels too often over-politicise the demographic categorisations of political cleavages. In place of "race" I will use "ethnicity". Although these are both social constructs, "race" has embedded in political connotations and implications, especially in the case of Fiji. I have only used the term "race" where applicable in the narrowest context.

16 Where literature excusing the overthrow of 1987 as necessity is prominent, literature arguing the same excusing the 2000 overthrow is rare. Clear linkages between chiefly elites and the protagonists of the 2000 overthrow, in the form of legal convictions (as is discussed in chapter five), undermine arguments that ethnicity was solely responsible for the 2000 overthrow. As a result, there is little literature purporting these explanations of the polity after the 2000 overthrow.

Ravuvu, The Facade of Democracy: Fijian Struggles for Political Control 1830-1987.; Dean and Ritova, Rabuka: No Other Way.; Bole, "Fiji's Chiefly System and Its Pattern of Political Self-Reliance.", Scarr, Fiji: Politics of Illusion, the Military Coups in Fiji

${ }_{17}$ Dean and Ritova, Rabuka: No Other Way. 
embedded in these processes, providing political stability and harmony to Fiji's institutions of government. ${ }^{18}$

Fiji's ethnic communities are presented by these scholars as immutable political entities and they reject the viability of any political cleavage in Fiji other than ethnicity. Ravuvu infamously described Fiji as a community riddled with entrenched ethnic antagonism, stating “PPacific-] Fijians generally perceive Indians (Indo-Fijians) as mean, stingy, crafty and demanding to the extent of being considered greedy, inconsiderate and grasping, uncooperative, egoistic and calculating." ${ }^{, 19}$ He suggests those who seek the removal of ethnic politics merely do so for self-interested reasons, namely to enhance their personal position within their ethnic group. ${ }^{20}$ Scarr support these sentiments in refuting the raison d'être of the Fijian Labour Party, labelling the Labour Party merely a front for the ethnically focused Indo-Fijian National Federation Party and asserting that materialist interpretations of political conflict are inapplicable to the case of Fiji. ${ }^{21}$ In proposing a solution to the rife ethnic conflict Ravuvu argues, that without full awareness of differences in Fiji's ethnic communities and appropriate constitutional provisions acknowledging them, no realistic form of democracy can be achieved in Fiji. ${ }^{22}$

Inherent in these arguments is a claim that Fiji's chiefly system is unique, and deserves a reserved place at the top of Fiji's political hierarchy. Ravuvu concludes his influential text, ${ }^{23}$ by asserting "[Pacific-] Fijians, nevertheless, must be assured of a degree of political paramountcy if all ethnic groups are to live together peacefully." ${ }^{24} \mathrm{He}$ advocated a democratic system in which Pacific-Fijian's unique relationship to the state of Fiji, as the indigenous ethnic grouping, would be recognised through institutional privileges. ${ }^{25} \mathrm{He}$ proposes the placement of ethnic privilege above equal contestation of political office. This was illustrated in his design of Fiji's 1990 Constitution, with the disproportionate distribution of electoral seats and gerrymandering of electorates entrenching a PacificFijian majority in the House of Representatives. ${ }^{26}$

\footnotetext{
18 Bole, "Fiji's Chiefly System and Its Pattern of Political Self-Reliance."

${ }^{19}$ Ravuvu, The Facade of Democracy: Fijian Struggles for Political Control 1830-1987, p .57.

20 _ , "Culture and Traditions: Implications for Modern Nation Building."

${ }^{21}$ Scarr, Fiji: Politics of Illusion, the Military Coups in Fïi pp. 29-31, 35.

22 Ravuvu, "Culture and Traditions: Implications for Modern Nation Building," p. 65.

23 _ The Facade of Democracy: Fijian Struggles for Political Control 1830-1987.

24 Ibid., p. 99.

25 Ibid.

${ }^{26}$ Ibid.
} 
The origin and function of the chiefly system is presented as the traditional social and political apex within the Pacific-Fijian community. From this observers contend that it is Fiji's supreme political hierarchy, and must be entrenched to recognise its special position. ${ }^{27}$ In reflecting on the 1987 coups, Bole and Ravuvu suggest that if the chiefs are not constitutionally provided the position they deserve, they will eventually achieve through whichever means necessary. ${ }^{28}$ Bole argues that, even with the presence of electoral institutions, it is inevitable that the chiefly hierarchy, as the highest social structure in Fiji, will reign supreme, excusing the chiefs' overthrow of elected government in 1987 as a quasi-natural social process. ${ }^{29}$ Ravuvu has even argued that the chiefly system is inherently democratic and egalitarian, in that it provides checks and balances on chiefs' power. The 'checks and balances' described by Ravuvu, however, posses no little democratic value. ${ }^{30}$

These descriptions of the chiefs' dominance over Fijian society rest on an interpretation of the Pacific-Fijian social structure that is static, ignoring the presence of change within these social hierarchies. ${ }^{31}$ These highly idealistic presentations of the chiefly system, however, have not gone unchallenged. The 1959 Spate Report cited the irrelevance of the chiefly hierarchy in modern Fiji as it neared independence. Spate reported that the chiefly system had become an end in itself, noting it was created and has been sustained merely for aesthetic reasons to preserve the pre-colonial traditional Pacific-Fijian way of life. ${ }^{32}$ Nayacakalou noted that the chiefly system entrenched in the colonial Fijian administration for the maintenance of the traditional way of life, had failed to develop into a modern political institution, as the colonial administration had hoped. ${ }^{33}$ The threat of modernity to the legitimacy of the chiefly system had not gone unnoticed by chiefly elites. In 1983, the

\footnotetext{
${ }^{27}$ Bole, "Fiji's Chiefly System and Its Pattern of Political Self-Reliance."

28 Ibid.; Ravuvu, "Culture and Traditions: Implications for Modern Nation Building."

29 These comments came in the aftermath of the 1987 coup and the rewriting of constitution and electoral system, as a means of legitimising both actions as inevitability. Bole, "Fiji's Chiefly System and Its Pattern of Political Self-Reliance."

${ }^{30}$ Unfortunately these checks on power described provide no non-violent checks on power. Rather Ravuvu details the killing or overthrow of a chief as justified if they abuse the power granted under Pacific-Fijian custom. This does not align with aims of democratic governance, the removal of violence from the processes of achieving governance. Ravuvu, "The Fijian Chiefly System and the Democratic Process."

${ }^{31}$ Bole, "Fiji's Chiefly System and Its Pattern of Political Self-Reliance."; Ravuvu, The Facade of Democracy: Fijian Struggles for Political Control 1830-1987.; __ , "The Fijian Chiefly System and the Democratic Process." This is a also a key theme of Scarr's academic writings about the chiefly elite in their role in Fijian society. Deryck Scarr, Ratu Sukuna: Soldier, Statesman, Man of Two Worlds (London and Basingstoke: Macmilliam Education Limited, 1980).; __ Fiji: A Short History (Hawaii: The Institute for Polynesian Studies, 1984).

32 Spate predicted that left to its own devices, it would crumble in the modern world. O. H. K. Spate, "The Fijian People: Economic Problems and Prospects," ed. Legislative Council of Fiji (Suva: Colony of Fiji Government Press, 1959), p. 8.

${ }^{33}$ Rusiate R. Nayacakalou, Leadership in Fiji (Melbourne: Oxford University Press, 1975), pp. 85, 92.
} 
Council of Chiefs appointed a review team ${ }^{34}$ to investigate the reorganisation of the chiefly controlled Fijian Provincial Administration (of which the Council of Chiefs was the highest authority), to halt the decay of its legitimacy. ${ }^{35}$

The literature that focuses on ethnicity also fails to acknowledge that the chiefs' dominance after independence was the product of colonial policies. France has provided a detailed analysis of the development of colonial rule and the institutionalisation of the chiefs' rule through the land-tenure system. ${ }^{36}$ Rather than the chiefly elite possessing hierarchical control over Pacific-Fijians for traditional reasons, the chiefly hierarchy was, and continues to be, perpetuated through illiberal institutions remaining from colonial indirect rule. In their highly idealistic presentation of chiefly hierarchy, proponents of ethnic based explanations as the source of conflict in Fiji, fail to report the colonial history from which the post-colonial chiefly elite has evolved.

In their analysis of the failing of Fijian democracy, proponents of ethnic antagonism hold that electoral governance was only ever permissible whilst it reinforced traditional hierarchy. They excuse authoritarianism, a necessity due to the extreme nature of Fiji's ethnic conflict. Although proponents of ethnicity explain why electoral results were overturned when they provided non-chiefly-backed parties government, they fail to demonstrate the source of the elites' power, beyond weak claims of social legitimacy and traditionalism.

\section{Historical revisionist explanations}

Historical revisionist writing on the failings of Fijian democracy clearly outlines the presence of an elite that has subverted electoral governance in Fiji. ${ }^{37}$ Writers in this

\footnotetext{
${ }^{34}$ Filipe Bole was charged with the appointment of the review team. At that time Bole was the Director of the Pacific Islands Development Programme at the East-West Centre Honolulu.

${ }^{35}$ Rodney V. Cole, Stephen I. Levine, and Anare V. Matahau, "The Fijian Provincial Administration," (Honolulu: Pacific Islands Development Program, East-West Center, 1984).

36 This is detailed in the following chapter. Peter France, The Charter of Land: Custom and Colonization in Fiji (Melbourne: Oxford University Press, 1969).

${ }^{37}$ Simione Durutalo, "Na Lotu, Na Vanua, Na Mataintu/the Church, Tradition and the State: The Paramountcy of Fijian Interest and the Polarisation of Ethnicity," in South Pacific Forum Working Paper no. 6 (Suva: Sociology Society, School of Social \& Economic Development, University of the South Pacific, 1986).; Robert Norton, Race and Politics in Fiji, 2nd ed. (St Lucia: University of Queensland Press, 1990).; Robert T. Robertson and Akosita Tamanisau, Fiji: Shattered Coups (Leichhardt, New South Wales: Pluto Press 1988).; Stephanie Lawson, Tradition Versus Democracy in the South Pacific: Fiji, Tonga and Western Samoa
} 
tradition argue Fiji's intertwined power structures, are a direct result of colonial administration and maintained by false consciousness. Where proponents of ethnicity hold ethnic conflict and the need to maintain tradition causes authoritarianism, historical revisionists argue that it is authoritarian features of Fiji's polity that have promoted ethnic conflict. The maintenance of communal politics has reinforced the position of the chiefly elite that has dominated Fiji since independence.

The historical revisionists' explanations of the polity reject the perspective that politics in Fiji was simply a matter of ethnic representation. As one of the first proponents of a class interpretation of Fiji's political structures, Durutalo critiques Fisk's pluralist "three Fiji's"s8 explanations of the polity. These revisionist arguments instead contend that multiethnic ideologies are used by elites to mask class rule. ${ }^{39}$ These proponents argue ethnicity has merely been a function of class, stressing the politicisation of ethnicity. ${ }^{40}$ Norton illustrates that it was colonial government and its socio-political and economic governance of Fiji that left it partitioned along ethnic lines. These partitions gave rise to the political communalism of the ethnically divided peoples in Fiji. ${ }^{41}$ Howard labels the chiefly elite an oligarchy, which has used and promoted communalism to undermine the threatening class

(Cambridge: Cambridge University Press, 1996).; —_ The Failure of Democratic Politics in Fiji (Oxford: Claredon Press; Oxford University Press, 1991).; Robert T. Robertson and William Sutherland, Government by the Gun: The Unfinished Business of Fiji's 2000 Coup (Annaadale, New South Wales: Pluto Press, 2001).; William Sutherland, Beyond the Politics of Race: An Alternative History of Fiji to 1992, Political and Social Change Monograph 15 (Canberra: Department of Political and Social Change, Research School of Pacific Studies, Australian National University, 1992), William E. H. Tagupa, "The 1987 Westminster Constitutional Crisis in Fiji," Pacific Studies 12, no. 1 (1988).; Brij V. Lal, Power and Prejudice: The Making of the Fiji Crisis (Wellington: New Zealand Institute of International Affairs, 1988).; ___, "Rhetoric and Reality: The Dilemmas of Contemporary Fijian Politics," in Culture and Democracy in the South Pacific, ed. Ron Crocombe, et al. (Suva: Institute of Pacific Studies, University of the South Pacific, 1992).; Alumita Durutalo, "Elections and the Dilemma of Indigenous Fijian Political Unity," in Fiji before the Storm: Elections and the Politics of Development, ed. Brij V. Lal (Canberra: Asia Pacific Press, Southwood Press Pty Limited, 2000).; Jay Narayan, The Political Economy of Fiji (Suva: South Pacific Review Press, 1984).

38 The pluralist interpretation of the polity has been used contextually by many academic writers in their description of the development of Fijian politics. This clean interpretation of natural forming cleavages within the polity breaks Fiji into the seemingly natural categorisations of Pacific-Fijians, Indo-Fijians and Europeans, through which British colonial administration chose to govern Fiji. A pluralist interpretation of the polity, although apt in a description of how politics has played out through electoral mediums, fails to address the formation of these political groups and the roots underpinning their division. E. H. Fisk, The Political Economy of Independent Fiji (Wellington and Auckland: A. H. \& A. W. Reed, 1970).; Durutalo, "Na Lotu, $\mathrm{Na}$ Vanua, Na Mataintu/the Church, Tradition and the State: The Paramountcy of Fijian Interest and the Polarisation of Ethnicity."

${ }^{39}$ Robertson and Sutherland, Government by the Gun: The Unfinished Business of Fiji's 2000 Coup.; Tagupa, "The 1987 Westminster Constitutional Crisis in Fiji."; Tim Bayliss-Smith et al., Islands, Islanders and the World: The Colonial and Post-Colonial of Eastern Fiji, Cambridge Human Geography (Cambridge: Cambridge University Press, 1988).

40 Sutherland, Beyond the Politics of Race: An Alternative History of Fiji to 1992.; Tagupa, "The 1987 Westminster Constitutional Crisis in Fiji."

${ }^{41}$ Durutalo, "Na Lotu, Na Vanua, Na Mataintu/the Church, Tradition and the State: The Paramountcy of Fijian Interest and the Polarisation of Ethnicity." 
cohesion from below, through policies of divide and rule. ${ }^{42}$ Ethnic identities have been exploited by elites for their own political needs, as the maintenance of an ethnic consciousness has sustained communal politics and chiefly elites' control of government. ${ }^{43}$ The Council of Chiefs has positioned itself as the dominant link and actor between the principal chiefs in national politics and the Fijian population, and as the suppressor of Fijian democracy. ${ }^{44}$

These historical revisionists refute claims of the traditional status of the Council of Chiefs as an institution of social importance and Pacific-Fijian tradition. Norton identifies links between colonial political institutions and 'modern' chiefly elites as well the elite's use of their hierarchy to subvert political outcomes. ${ }^{45}$ The Council of Chiefs and the Pacific-Fijian 'traditional' social order rests on colonially infrastructure, which colonial authorities established and through which they channelled political patronage to facilitate colonial their rule. ${ }^{46}$ Further, the Council of Chiefs itself did not exist until Governor Gordon set it up for colonial purposes in 1875 as a cheap and effective means of ruling Fiji. ${ }^{47}$

Among historical revisionists, debate rages as to the composition of the elite who usurped government in 1987. Predominantly this has focused on the centrality of Council of Chiefs as the apex of Pacific-Fijian social hierarchy and political chiefly authority. ${ }^{48}$ Whilst others suggest a coalition of foreign and Indo-Fijian business interests backed the chiefs' in their overthrow of government. ${ }^{49}$ Little substantive evidence has been presented affirming the involvement of big business in the 1987 coup, whereas vast evidence exists demonstrating the roles of high chiefs in the coup.

42 Michael C. Howard, Fiji: Race and Politics in an Island State (Vancouver: University of British Columbia Press, 1991).

43 Durutalo, "Na Lotu, Na Vanua, Na Mataintu/the Church, Tradition and the State: The Paramountcy of Fijian Interest and the Polarisation of Ethnicity."

${ }^{44}$ Norton, Race and Politics in Fiji.

45 Robert Norton, Race and Politics in Fiji, 1st ed. (St Lucia and New York: University of Queensland Press and St Martin's Press, 1977). was the first scholarly text to focus on the peoples of Fiji as a national society. Norton, Race and Politics in Fiji.

${ }^{46}$ Durutalo, "Na Lotu, Na Vanua, Na Mataintu/the Church, Tradition and the State: The Paramountcy of Fijian Interest and the Polarisation of Ethnicity."

47 Sutherland, Beyond the Politics of Race: An Alternative History of Fiji to 1992.

48 Durutalo, "Na Lotu, Na Vanua, Na Mataintu/the Church, Tradition and the State: The Paramountcy of Fijian Interest and the Polarisation of Ethnicity."; Sutherland, Beyond the Politics of Race: An Alternative History of Fiji to 1992, Norton, Race and Politics in Fiji.

49 Tagupa, "The 1987 Westminster Constitutional Crisis in Fiji."; Robertson and Tamanisau, Fiji: Shattered Coups.; Howard, Fiji: Race and Politics in an Island State; Lal, "Rhetoric and Reality: The Dilemmas of Contemporary Fijian Politics," p. 99. 
The visible conflicts within the post-1987 coup interim government between chiefs, demonstrated the coup of 1987 was not undertaken for the noble causes its protagonists claimed. ${ }^{50}$ Rather, events following the coup unfolded, a veil was lifted exposing personal interests and the myth of nobility underlying 'Pacific-Fijian' chiefly paramountcy. These claims by chiefly elite were merely used to obscure the realities of class rule. In addressing the 2000 overthrow, Robertson and Sutherland reject claims of Indo-Fijian privilege over Pacific-Fijians, blaming instead privileged chiefs' who manipulate Pacific-Fijian commoners, economically and politically. ${ }^{51}$ Chiefs' generated hysteria regarding their fears of loss of government and the potential reform of the land-tenure system are unfounded. These claims are unfounded, however, given the senatorial veto of the Council of Chiefs nominees is sufficient to halt any reform of these provisions.

Proponents of critical history present clear arguments as to how chiefly elites have suppressed democratic outcomes that threatened their dominance of the polity. In doing this, however, they fail to analyse how the infrastructure of elite control. These historical revisionist arguments, in demonstrating the maintenance of colonial institutions, fail to explain the sources of elite power that have undermined government. Although the Labour Party successfully tapped into class sentiments, winning government twice, its tenure in government was overthrown swiftly by chiefs'. These arguments hint at the presence of class identities within Fiji but fail to explain, why class-consciousness did not translate to the reordering of Fiji's social order after independence. Something deeper than political identities and false consciousness has held this system together. Attempts at forming crossethnic alliances among the poorest Fijians have not just been undermined by communal politicking, but rather through dominant material controls of the chiefly elite over society.

Neither those who have viewed Fiji through a lens of ethnicity nor those who have considered it through revisionist history have sufficiently described the power structures underlying Fiji's polity. Alone explanations based on ethnicity and colonial history misdiagnose the realities of Fijian politics. Such arguments are intertwined and intimately related. Class hierarchies and ethnic identities overlap in that Pacific-Fijian chiefs occupy a privileged economic and social position in the Fijian society, which has provided them the means to usurp elected government. Both arguments of historical revisionism and ethnic identities, however, have overlooked the linchpin that holds together the chiefs' control of

50 Sutherland, Beyond the Politics of Race: An Alternative History of Fiji to 1992.

${ }^{51}$ Robertson and Sutherland, Government by the Gun: The Unfinished Business of Fiji's 2000 Coup. 
Fiji's political system. To understand the power structures underlying the polity, and how the chiefly elite has usurped government at its will, an institutional analysis of the Fiji's economy, and Fiji's position in the world economic order, is necessary. Reflection on broader literature from the field of political economy provides insight into these underlying power structures and the sources of the chiefly elites' power.

\section{Maintaining authoritarianism in Fiji}

Fiji has neither a liberal land-tenure system nor democratic political institutions. Fiji's chiefly elite controls the key economic institutions within the economy providing it vast economic advantages and social controls over Fijian society. These institutional advantages were provided to the chiefs under colonial rule, and have never been reformed since. Of the institutional advantages provided to the elite, the flow of rental income from 'native land' leases directly to chiefly elites has served to perpetuate the elites' dominance over the Fijian polity. These sinecures, and Fiji's illiberal land-tenure system have been maintained in part through Fiji's position in the world economy. A reflection on wider literature offers insight into the structure of Fiji's entrenched elite, the illiberal institutions it controls and the source of the material advantage, which has enabled it to usurp elected government on several occasions.

\section{Fiji's domestic institutional structures are illiberal}

Institution-focused economists examine the consequence of monopolies and rent-seeking ${ }^{52}$ on the efficiency of production. Krueger argues rent-seeking behaviour is present in all economies, and comes in the form of regulatory restrictions or illegal behaviour such as bribery or corruption. ${ }^{53}$ Tullock argues that monopolies facilitate inefficient production, and encourage rent-extracting behaviour within industry. ${ }^{54}$ Monopolies require the use of inefficient technology to maintain price levels and satisfy rent-seeking demands. Through

52 Rent-seeking is intended in a broad sense, as a return derived from market power or coercion, typically a monopoly, rather than by competition, it is also applicable in its classic form. Ronald Rogowski, "Trade and Variety of Democratic Institutions," International Organization 41, no. 2 (1987).

${ }_{53}$ Anne O. Krueger, "The Political Economy of the Rent-Seeking Society," The American Economic Review 64, no. 3 (1974).

${ }^{54}$ Gordon Tullock, "The Costs of Special Privilege," in Perspectives on Positive Political Economy, ed. James E. Alt and Kenneth A. Shepsle, Political Economy of Institutions and Decisions (New York: Cambridge University Press, 1990).; — , "The Welfare Cost of Tariffs, Monopolies and Theft," Western Economic Journal 5 (1967). 
this behaviour, monopolies incur large social costs as a weight on production, extracting far beyond what they would receive under an efficient system of production. This rentseeking, whether legal or illegal, as Krueger argues, produces far greater inefficiency and social cost than is produced by trade restrictions, such a tariffs. ${ }^{55}$ Rogowski adds that, in heavily trade-dependent economies, the consequence of monopoly controls are heightened. The rent-seeking facilitated by monopoly actors and the inefficiencies created by them, induce fatal inefficiencies that cripple industries, and economies. ${ }^{56}$

Fiji's land-tenure system and sugar industry is riddled with rent-seeking monopoly actors. This rent-seeking behaviour is facilitated within the land-tenure system through the close proximity of high chiefs to land valuations and lease rent setting. Chiefs have a vested interest in setting highly inflated land valuations and rental prices as they are the major recipients of native land lease rents.

In reviewing successful democratisation in post-colonial transitions, Lipset observes that success is most prominent in states where a competitive domestic market economy has been established. ${ }^{57}$ This is because competitive markets have proven themselves to be the best way to reduce the impact of nepotistic networks and the room for rent-seeking by elites - remnant from colonial or authoritarian rule - who still possess privileged access to state power and resources. ${ }^{58}$ Moore's modernisation theorem "No bourgeois, no democracy," also speaks to the need to diffuse the monopoly elite's influence over the state and material resources at democratic transition. ${ }^{59}$ This assertion contends that a politically mobilised landed class, who depend on the rule of law for maintenance of property rights is needed to sustain democratic institutions. ${ }^{60}$ Without the development of a middle class and without it receiving a share of the elite's wealth and power, the elite possesses a monopoly over the institutions of power, and can undermine electoral institutions at will.

At the moment of transition to independence and electoral rule, the controls of the chiefly elite over Fijian society were not altered. Rather, the chiefs' institutionalised privilege and,

\footnotetext{
${ }^{55}$ Krueger, "The Political Economy of the Rent-Seeking Society," p. 291.

56 Rogowski, "Trade and Variety of Democratic Institutions."

57 Seymour Martin Lipset, "The Social Requisites of Democracy Revisited: 1993 Presidential Address," American Sociological Review 59, no. 1 (1994): p. 3. 58 Ibid.

${ }^{59}$ Barrington Moore, Jnr., Social Origins of Dictatorship and Democracy: Lord and Peasent in the Making of the Modern World (Boston: Beacon Press, 1966), p. 418. ${ }^{60}$ Ibid.
} 
importantly its ability extract rents was entrenched within the constitution. Hence, Fiji's democratic transition produced no reform of the material controls of the economy. Chiefs' retained control of the resources that colonial authorities had given them a century earlier.

Moore's assertion proves to be apt in the case of Fiji, where control over land is vested in the highest chiefs. The legal state of native land has inhibited the development of property ownership as a bulwark of electoral institutions, as Moore argues. Although there is a perception that the legal state of native land provides all Pacific-Fijians ownership of their tribal lands, the inability to utilise or trade the asset sits in conflict with this. Thus, PacificFijians have not developed recognition of the necessity of the rule of law and the importance of checks and balances on the power of the state in protecting their ownership rights, undermining the legitimacy of elected government. In reality, the legal state of native land has inhibited, rather than extended, ownership of property to the masses. This was made possible by Fiji's position in the world economy, as a former British colonial sugar producer, which served to maintain its inflated land-tenure system and the authoritarian elite's patronage networks.

\section{How Fiji's illiberal structures have been maintained}

Fiji's position in the international economy has made possible chiefs' efforts to maintain the colonial designed land-tenure system and their position within Fijian society and politics. Fiji's position in the world economy resembles post-Marxist analyses of economies dependent on the export of primary goods in the international economy. ${ }^{61}$ Such analyses view the world as a single system in which there is a hierarchical division of labour between economies. Fiji's dependence on sugar exports under the Sugar Protocol in particular makes it dependent on commercial relations with the European Union. Post-Marxist analyses also argue this division of labour between societies has an impact on the internal organisation of societies.

Observers disagree as to how integration into an economic division of labour and shapes domestic political structures. Wallerstein demonstrates how export dependence on primary products can reinforce repressive systems of labour relations. ${ }^{62}$ Rogowski and Gourevitch

${ }^{61}$ Immanuel Wallerstein, The Modern World-System: Capitalist Agriculture and the Origins of the European WorldEconomy in the Sixteenth Century, ed. Charles Tilly, Studies in Social Discontinuity (New York: Academic Press, 1974), _ , "The Rise and Future Demise of the World Capitalist System: Concepts for Comparative Analysis," Comparative Studies in Social History 16, no. 4 (1974).

${ }^{62}$ Wallerstein, The Modern World-System: Capitalist Agriculture and the Origins of the European World-Economy in the 
point out that while external structure has an influence, it does not determine the domestic structure of internal politics. ${ }^{63}$ Fiji's position within Europe's preferential trade system reinforces a post-colonial authoritarian system based on chiefly control of land tenure.

These post-Marxist explanations of states' colonial and post-colonial trade relations speak to Fiji's trade relations with the world economy and the material structures that underlie its political institutions. Fiji's sugar industry has been a recipient of, and continues to be dependent on, preferential access to markets in Europe. Fiji's ability to sell sugar to the European Union well above world market prices has, in part, permitted the maintenance the political institutions established under colonial rule. Under British colonial rule, sugar was developed as a cash crop and exported back to Britain. To facilitate smooth colonial governance of the colony British authorities granted control of Fiji's land-tenure system to the Pacific-Fijian chiefly elite. This provided the elite control over material resources extracted from sugar production providing it patronage resources assisting colonial governance. At independence, despite the arrival of electoral institutions to reorder political hierarchy in Fiji, the colonial mechanism of patronage was not reformed. In addition, colonial development of sugar as Fijis only cash crop has left its economy heavily dependent on favourable subsidy payments. These conditions have permitted the maintenance of the chiefs' control over Fijian society.

Developments in Fiji are comparable to events earlier in history in region geographically far removed from the South Pacific. The interdependence between Fiji's position in the international economy and the persistence of a feudal elite to the present day, mirrors Alexander Gerschenkron's explanation the survival of Germany's East-Elbian landed aristocracy (Junker's) as a dominant political group in the political development of Wilhelmine Germany. ${ }^{64}$ Gerschenkron explains how domestic tariff policies segregated Germany from competitive international grain market prices, permitting Junker's to

Sixteenth Century.; _ _ "The Rise and Future Demise of the World Capitalist System: Concepts for Comparative Analysis."

63 Peter Gourevtich, "The Second Image Reversed: The International Sources of Domestic Politics," International Organization 32, no. 4 (1978).; —_ Politics in Hard Times: Comparative Responses to International Economic Crises, ed. Peter J. Katzenstein, Cornell Studies in Political Economy (Ithaca and London: Cornell University Press, 1986).; Ronald Rogowski, Commerce and Coalitions: How Trade Affects Domestic Political Alignments (Princeton, New Jersey: Princeton University Press, 1989).; Rogowski, "Trade and Variety of Democratic Institutions."

64 Alexander Gerschenkron, Bread and Democracy in Germany (New York: Cornell University Press, 1989). Also Peter Gourevitch's generalised discussion of how world trade crises affected political structures in Europe and North America in the late $19^{\text {th }}$ Century in Peter Gourevtich, "International Trade, Domestic Coalitions, and Liberty: Comparative Responses to the Crisis of 1973-1896," Journal of Interdisciplinary History 8, no. 2 (1977). 
maintain their position within the German economy, and therefore their privileged place within society and politics. The Junker's maintained their hold over German political development and dominance over German society, at the expense of democratisation. Not domestically controlled tariffs, but rather, trade preferences have shielded Fiji's landed aristocracy from the pressures of international commercial competition, permitting them to retain their position against efforts to create democracy in Fiji. The title of the present work is the author's acknowledgement of the debt owed to Gerschenkron's analysis.

\section{Methodology}

This research provides an examination of Fiji's political institutions demonstrating how authoritarian actors have reasserted their control political institutions repeatedly since independence. It analyses each of Fiji's three constitutions, demonstrating why Fiji has never been a democracy. It examines the economic and political power structures underlying Fiji's polity, and how these have ensured the continuation of authoritarian rule in Fiji, despite the presence of electoral institutions.

In addressing the persistence of authoritarianism in Fiji, I propose the following hypothesis: Fiji's polity is dominated by authoritarian institutions, which possess the means to usurp elected governments at their will. These authoritarian institutions are controlled by a chiefly elite that was provided material advantages over the rest of Fijian society under British colonial rule. This chiefly elite possesses a monopoly over land in Fiji, allowing it to charge highly inflated lease rents, which have been sustained through the sugar industry's receipt of the EU's Sugar Protocol subsidy payments. The distribution of these rents down a hierarchical structure has perpetuated the chiefs' advantages over Fijian society. The result has been extreme instability in Fiji's elected political institutions.

To test this hypothesis this thesis will demonstrate the links between Fiji's position in the international economy and the structure of Fiji's domestic politics. I will explore the following research questions to demonstrate the power structures underlying Fiji's polity and the causes of sustained authoritarianism: What perpetuates chiefly hierarchy over Fijian society? How have chiefly advantages translated into political control? How have Fiji's unique institutions sustained themselves? Have coups occurred when democracy has been 
at its weakest or strongest? In addressing these questions, this thesis will provide empirical evidence demonstrating the power structures underling Fiji's economy and polity, and the overwhelming influence these structures have on its governance. In conducting this research, I must also be aware of evidence to the contrary of the tenets of the hypothesis that prove it inaccurate or incorrect. Where these instances arise, I must ascertain whether they undermine the linkages between the tenets underlying the argument of thesis.

The first question outlined seeks to determine what institutional mechanisms have perpetuated chiefly hierarchy over Fijian society. This will examine how a Pacific-Fijian chiefly hierarchy remained prominent through colonial rule and since independence. It will analyse what institutional mechanisms exist that provide advantage to chiefs over other Fijians. It will also examine how these institutional advantages have been maintained within Fiji's constitutions. Counter evidence to this will include the absence of institutional mechanisms providing advantage to chiefly elites and the absence of any constitutional protections of these.

The second seeks to analyse how have Fiji's illiberal institutions been buffered from economic pressure on world markets. It will examine the structure of Fiji's illiberal institutions and what permits their operations. It will focus on the Fijian sugar industry's receipt of EU subsidy payments far above world market prices. It will demonstrate how chiefly elite's control these illiberal institutions have provided it vast dominance over the Fijian economy. Counter evidence to this will include dominant sources of socio-economic power other than control of the land-tenure system and its distribution of lease rents.

Finally, this thesis will reflect on whether interruptions of Fijian democracy occurred when it has been at its weakest, or when they threatened to impinge on core chiefly institutions. Specifically, it examines whether the coups have overthrown governments at times when electoral contestability seemed strong producing changes in governments or rather when electoral institutions struggled to produce a change in government. Counter evidence to this will include instances where the chiefly elite acted as a guardian or protector of electoral institutions or where the chiefly elite actively discouraged authoritarian behaviour or rhetoric.

The following chapter analyses each of Fiji's three constitutions, demonstrating the 
presence of parallel electoral and authoritarian structures within the polity, undermining electoral institutions' ability to be democratic. It examines the institutional mechanisms the chiefly elite has possessed within the economy and society and how these mechanisms have provided the means for chiefs to usurp government at will. Chapter Four and Five explain how and why, since independence this chiefly elite has acted to reassert itself whenever electoral institutions have threatened their control of government. These chapters demonstrate how each time electoral institutions have provided non-chiefly backed parties government, it has been overthrown.

\section{Scope of the Thesis}

The temporal limitations imposed on a Masters of Arts thesis necessarily restrict the scope of its conclusions, its depth of argument, and the evidence that can be gathered. This thesis, therefore, offers a limited, and by no means exhaustive, examination of the economic power structures underlying Fiji's land-tenure system and in particular the role of the sugar industry within Fiji's political economy.

This thesis draws on a combination of primary documentation and secondary literature. In its analysis of political and economic institutions, it examines each of Fiji's three constitutions, Acts of Parliament, land valuation documents, and the Native Land Trust Board's (NLTB) Annual Reports going back forty years. To round out the examination of Fiji's political history, this thesis consults secondary literature on the topic in a comprehensive manner.

\section{Constraints}

The largest constraint on this research is the unavailability of complete data on all native land lease rents. The NLTB refused to release to the author lease rent data. Accordingly, this study can only consult lease rent data already available in the public domain. The public availability of land units' valuations provides a limited amount of data on ALTA lease rents, and the relatively equitable earnings of sugar farmers make analysis of its inflated rents possible. The decentralised nature of Fiji's tourism lease agreements, on the other hand, makes study of inflated tourism lease rents unrealistic. Unlike the native land sugar lease agreements, which are universally governed by one piece of legislation, tourism lease 
agreements are individually and privately negotiated and so the size of premium payments and annual rents is isolated from the public domain. As Fiji's largest earner of foreign currency and under the unlimited size of these lease rents, it would be expected that tourism leases provide more income to the proprietary units than sugar leases, however, due to the absence of publically available material on this, of the size of this cannot be estimated credibly. ${ }^{65}$

The vast inaccuracies presented within the NLTB's annual reports makes ascertaining actual commercial activity of the institution problematic. The reliability of the data present in these annual reports is limited by the NLTB's application self-prescribed accounting standards. This opaque financial management by the NLTB's of its own operations limits the ability to analyse its role within the economy. This also reinforces the claim of the thesis, that the NLTB's deliberate obfuscation within its financial records has been a deliberate effort to operate as an unchecked financial institution.

Due to the political situation in Fiji at the time fieldwork was undertaken, ${ }^{66}$ Human Ethics approval was not granted by Victoria University of Wellington to conduct interviews while in Suva and Lautoka. This severely constrained the author's ability to obtain primary source material, specifically with regard to the financial operations and management practices of the NLTB. It also constrained investigation of the strength of the chiefs' patronage networks within Pacific-Fijian communities.

\section{Timeframe of analysis}

Of particular note is that this study excludes the political events after 2005. I have deliberately excluded the military coup d'état on 5 December 2006 from this study. The meaning and outcome of the events after December 2006 remain undetermined. The coup may be interpreted as a product of the re-emergence of intra-Pacific-Fijian rivalries, sidelined after the putsch by the success of the Soqosoqo Duavata ni Lewenivanua (SDL) Party since the 2000 military overthrow. It might also be interpreted as a counter-coup, as Land Force Commander Colonel Pita Driti has described it. ${ }^{67}$ However, as the interim

\footnotetext{
${ }^{65}$ Although averages can be estimated through the division of total tourism leases by total lease agreements, these figures are not reliable. The NLTB's financial reporting practices makes any of its statistics not credible. In addition to this, the financial details of tourism leases are not provided to the public.

${ }^{66}$ Fieldwork was conducted between 16 August - 7 September 2008 in Suva and Lautoka, Fiji. During this time the RFMF still controlled the apparatus of government in Fiji and diplomatic relations between this Fijian government and the New Zealand government were tense.

${ }^{67}$ Pita Driti, "Pacific News," Morning Report, Radio New Zealand National, 3 April 2009.
} 
government has not handed power back to a civilian authority, in many ways the coup is not yet over. Therefore, analysis of this coup would be premature. This fact may also be a contributing factor to the absence of literature addressing the causes of coups and deeper structural analysis of the ever-changing Fijian polity. ${ }^{68}$

68 Very little academic literature has been published to date on this overthrow. Of that which has, it has presented a simple narrative of events readily available in newspapers of the time. Jon Fraenkel and Stewart Firth, From Election to Coup in Fiji: The 2006 Campaign and Its Aftermath (Canberra: The Australian National University Press and Asia Pacific Press, 2007). Even this text presents very little directly focused on the events of the coup and phenomenon underpinning it. However, days before the submission of this thesis a text on the 2006 coup was released. Jon Fraenkel, Stewart Firth, and Brij V. Lal, The 2006 Military Takeover in Fiji: A Coup to End All Coups? (Canberra: The Australian National University E Press, 2009). Due to the proximity of this books release to the submission of the thesis, I have not taken into account its analysis. 


\section{Chapter Three: Fiji's Parallel Authority Structures}

For seventeen years, Fiji seemed a perfect model of post-colonial democracy. After independence in 1970, Fiji followed peaceful processes of decolonisation that led many to see it as model of multicultural liberal democracy and a guiding light for the post-colonial Pacific. The structures underlying Fijian democracy, however, had not been tested. Although Fiji looked like the embodiment of liberal electoral democracy, an authoritarian elite was embedded in its political and economic structures. This elite had sufficient power to overthrow Fiji's democratic experiment whenever it deemed necessary.

The position of the Council of Chiefs, an unelected institution, within each of Fiji's three constitutions since independence, demonstrates the enduring influence of the Pacific-Fijian chiefly hierarchy in Fijian society. Created under colonial rule, the Council of Chiefs assisted British governance of the colony. Following independence, within the different constitutions, the Council has been granted notable statutory powers. Had the Council and its highest chiefs remained apolitical, supporting the rule of law and electoral results, the constitutional advantages provided to chiefs and the Council may have had little influence over the maintenance of electoral results. Nonetheless, there is clear evidence, that the Council of Chiefs and Fiji's highest chiefs have used their material and political privilege to undermine and overthrow electoral government whenever the results did not serve their interests. Under each of Fiji's three constitutions, chiefs received institutional economic advantages and controls over Fiji's productive resources that allowed them to undermine electoral institutions.

This chapter exposes the authoritarian institutions within Fiji's polity. First, it explains how Fiji has maintained the appearance of a democracy under the different constitutions, despite the consistent removal of elected governments. This section also demonstrates the loopholes in each constitution that allowed an authoritarian elite to operate in within these to restrict the impact of electoral results. Second, it explores how authoritarian structures govern Fiji's economy, examining the chiefly elite's control over key productive resources in Fiji. 


\section{Fiji's constitution and the placement of sovereignty within it}

Fiji appeared to be a constitutional liberal democracy. Its electoral institutions functioned uninterrupted $^{69}$ for seventeen years, from independence in 1970 until May 1987 when a military coup suspended elections. After five years of military rule, it reverted to elections in March 1992, with electoral institutions lasting until May 2000. To explain these lapses in electoral governance ${ }^{70}$ it is necessary to examine the distribution of power under Fiji's constitutions. This will also provide an insight into whether Fiji's institutions are democratic, as they seem.

Under each of Fiji's three constitutions, the distribution of sovereignty across the executive and legislature has changed little and the power structures underlying constitutional institutions been the focus of little reform. All three constitutions have reserved a place for the unelected Council of Chiefs, providing it influence over institutions in which sovereignty is embedded. The key advantages provided to the chiefly elite, through the Council of Chiefs, have remained relatively consistent across all three constitutions. The Council's position at the centre of Fiji's political institutions has challenged the maintenance of electoral institutions, and these institutions' status as democratic institutions.

The following section examines Fiji's three constitutions. It details the composition of Fiji's executive and legislature, and the appointment and electoral processes, which determine the composition of key political institutions. In discussing whether Fiji's political institutions are democratic, it particularly focuses on the role of the Council of Chiefs in constitutional institutions.

Fiji's 1970 Constitution was drafted to facilitate constructive governance and to support Fiji's transition from colonial governance to independent rule. Under the 1990 Constitution, Fiji's governmental institutions reflected the desires of the 1987 coup's principal backers. Finally, the constitutional reform of 1997 explicitly sought to provide an

${ }^{69}$ This does not take into account the 1977 'constitutional crisis' as discussed in Chapter Four.

${ }^{70} \mathrm{I}$ define electoral governance as the composition of government determined by elections. Although the Council of Chiefs' senatorial nominees' veto power inhibits Fiji's political institutions from being democratic. In turn, despite constitutional provisions allowing the cabinet to comprise members of the Senate (who are not elected), the prerogative to form the cabinet is granted to the leader of the party, or coalition of parties, who commands a majority of seats in the parliament. 
environment for cross-ethnic power sharing. Under each of the three constitutions, one can identify elements of democracy. Common to all constitutions was the diffusion of power across the legislature and the executive. The legislature comprised a bicameral parliament, with a Senate and a House of Representatives. The House of Representatives was the only institution that could propose legislation. The Senate can alter or vote down legislation. The executive comprises the cabinet, and is ceremonially headed by the President, but led by the Prime Minister. The cabinet is made up of individuals chosen by the Prime Minister from either the Senate or the House of Representatives. The leader of the party, or coalition of parties, with the most votes in Parliament attains the Prime Ministership, and then holds the prerogative to form the cabinet. Across Fijis three constitutions, processes of appointment and election of constitutional institutional have varied.

\section{The Head of State}

The office of Head of State has evolved with each of Fiji's constitutions. The Head of State holds executive authority over the state of Fiji and is the Commander-in-Chief of the military forces. ${ }^{71}$ Under the 1970 Constitution, the Head of State was the British Monarch represented by a Governor General based in Fiji. ${ }^{72}$ After the September 1987 coup, Fiji's second, Lieutenant-Colonel Sitiveni Ligamamada Rabuka ${ }^{73}$ declared Fiji a Republic and appointed Ratu Sir Penaia Kanatabatu Ganilau President of Fiji. ${ }^{74}$ Subsequently, under the 1990 Constitution, the office of the President was explicitly reserved for a Pacific-Fijian, to be appointed by the Council of Chiefs. ${ }^{75}$ This was altered under the 1997 Constitution, ${ }^{76}$ where the Council of Chiefs held the power of appoint of the President, but after consultation with the Prime Minister. ${ }^{77}$ The reserve Head of State is the Vice-President, who acts as the Head of State in the President's absence. ${ }^{78}$ The President holds the

${ }^{71}$ Constitution of the Republic of the Fiji Islands 1997, Act No. 13 of 1997 as amended by Act No. 5 of 1998. Chapter VII, Part 1, Section 85, 86, 87

72 Fiji 1970 Constitution. Chapter IV, Section 27

73 At the time of the May 1987 coup Rabuka was a Lieutenant-Colonel. Brij V. Lal, Islands of Turmoil: Elections and Politics in Fiji (Canberra: Asia Pacific Press 2006), p. 72. In Rabuka's authorised biography he is referred to as a Major-General. John Sharpham, Rabuke of Fiji: The Authorised Biography of Major-General Sitiveni Rabuka (Rockhampton, Queensland: Central Queensland University Press, 2000).

${ }^{74}$ Subsequently all high chiefs with chiefly title will only be referred to by their surname.

${ }^{75}$ Constitution of the Sovereign Democratic Republic of Fiji 1990.Chapter V, Section 31

76 As the 1997 Constitution was abrogated by the President of Fiji on 10 April 2009 I refer to the 1997 Constitution in the past tense.

${ }^{77}$ Constitution of the Republic of the Fiji Islands 1997, Act No. 13 of 1997 as amended by Act No. 5 of 1998. Chapter VII, Part 2, Section 90

${ }^{78}$ Under the 1970 Constitution, the Chief Justice filled this role. Under the 1990 Constitution, two VicePresidents shared the constitutional role. Under the 1997 Constitution, the Council of Chiefs appointed a single Vice-President after consultation with the Prime Minister. Constitution of the Sovereign Democratic 
constitutional power to intervene in constitutional conflicts or crises, where electoral results are ambiguous or where government is disrupted by external circumstances. The position of President has played a key role in direct of Fiji's history.

\section{The House of Representatives}

The House of Representatives is the lower house of the parliament and the only body that can present new legislation. It is also the only elected institution in Fiji's governmental institutions. Across the three constitutions, the distribution of seats between general, ethnically-designated communal and cross-ethnic constituencies, as well as the distribution of these seats has been the focus of persistent reform, see Table $1 .^{79}$

Table 1: Composition of the electoral seats in the House of Representatives across Fijis 1970, 1990 and 1997 Constitutions

\begin{tabular}{|l|c|c|c|c|c|c|c|c|c|}
\hline & \multicolumn{4}{|c|}{ Communal } & \multicolumn{3}{|c|}{ Cross-Ethnic } & General & Total \\
\cline { 2 - 9 } & $\begin{array}{c}\text { Pacific- } \\
\text { Fijian }\end{array}$ & $\begin{array}{c}\text { Indo- } \\
\text { Fijian }\end{array}$ & 'Other' & Rotuman & $\begin{array}{c}\text { Pacific- } \\
\text { Fijian }\end{array}$ & $\begin{array}{c}\text { Indo- } \\
\text { Fijian }\end{array}$ & 'Other' & & \\
\hline $\begin{array}{l}1970 \\
\text { Constitution }\end{array}$ & 12 & 12 & 3 & - & 10 & 10 & 5 & - & 52 \\
\hline $\begin{array}{l}1990 \\
\text { Constitution }\end{array}$ & 37 & 27 & 5 & 1 & - & - & - & - & 70 \\
\hline $\begin{array}{l}1997 \\
\text { Constitution }\end{array}$ & 23 & 19 & 3 & 1 & - & - & - & 25 & 71 \\
\hline
\end{tabular}

Source: Fiji 1970 Constitution; Constitution of the Sovereign Democratic Republic of Fiji 1990; Constitution of the Republic of the Fiji Islands 1997.

Under the 1970 Constitution, the House of Representatives had 52 seats. Electoral constituencies were divided between communal ethnic and national cross-ethnic constituencies. ${ }^{80}$ Of these 52 seats, 22 were reserved for Pacific-Fijians. ${ }^{81}$ Of these PacificFijian constituents elected 12 Pacific-Fijian Members of Parliament (MPs) ${ }^{82}$ from PacificFijian communal constituencies, and all Fijians elected 10 Pacific-Fijian MPs from PacificFijian national constituencies. ${ }^{83} 22$ seats were reserved for Indo-Fijians. ${ }^{84}$ Of these, IndoFijians elected 12 Indo-Fijian MPs from communal Indo-Fijian constituencies, and all

Republic of Fiji 1990.Chapter V, Section 31; Fiji 1970 Constitution. Chapter IV, Section 28; Constitution of the Republic of the Fiji Islands 1997. Chapter VIII, Part 1, Section 88

79 All ethnically reserved seats are referred to as "Fijian", "Indian" and "other". Whilst general seats are referred to as "general". I use "Pacific-Fijian" and "Indo-Fijian" for clarity and to avoid the numerous implications that accompany the use of these words in Fiji.

${ }^{80}$ Fiji 1970 Constitution. Chapter V, Part 1, Section 32 (1)

${ }^{81}$ Ibid.Chapter V, Part 1, Section 32 (3)

82 'Members of Pariament' refers to those members of the lower house, the House of Representatives.

${ }^{83}$ Fiji 1970 Constitution.Chapter V, Part 1, Section 32 (3)(a) and (b).

84 Ibid.Chapter V, Part 1, Section 32 (4). 
Fijians elected 10 Indo-Fijian MPs from Indo-Fijian national constituencies. ${ }^{85}$ The remaining eight were reserved for Fijians of 'other' ethnicities (neither Pacific-Fijian nor Indo-Fijian ethnicity). ${ }^{86}$ Of these eight seats, 'other' ethnic constituents elected three MPs from 'other' communal constituencies, and all Fijians elected five MPs from 'other' national constituencies. ${ }^{87}$

Under the 1990 Constitution, the lower house comprised of 70 seats. $^{88}$ All electoral constituencies were communal and all voting was communal. 37 seats were reserved for Pacific-Fijians, all of which were elected by Pacific-Fijian constituents. ${ }^{89} 27$ seats were reserved for Indo-Fijians, all of which were elected by Indo-Fijian constituents. ${ }^{90}$ One seat was reserved for a Rotuman, which was elected by the Rotuman constituency, ${ }^{91}$ and the remaining five seats were reserved for constituencies of 'other' ethnicities, elected by these 'other' ethnic constituents. ${ }^{92}$

Under the 1997 Constitution, the House of Representatives membership expanded by one to 71 seats. Electoral constituencies comprised a combination of both communal and general cross-ethnic constituencies. ${ }^{93}$ Of the 71 seats, 23 were reserved for Pacific-Fijians, all of which were elected by Pacific-Fijian constituents. ${ }^{94} 19$ seats were reserved for IndoFijians, all of which were elected by Indo-Fijian constituents. ${ }^{95}$ One seat was reserved for a Rotuman, which was elected by the Rotuman constituency, ${ }^{96}$ while, three seats were constituencies for voters of 'other' ethnicities. In addition, 25 seats were general non-ethnic constituencies, elected by all Fijian voters. ${ }^{97}$

\section{The Senate}

The Senate is the Fijian Parliament's upper house, it has power to approve, amend, or vote

\footnotetext{
${ }^{85}$ Ibid.Chapter V, Part 1, Section 32 (4)(a) and (b)

${ }^{86}$ Ibid.Chapter V, Part 1, Section 32 (5)

${ }^{87}$ Ibid.Chapter V, Part 1, Section 32 (5)(a) and (b)

88 Constitution of the Sovereign Democratic Republic of Fiji 1990.Chapter VI, Section 41(1)

${ }^{89}$ Ibid.Chapter VI, Section 41(3)

${ }^{90}$ Ibid.Chapter VI, Section 41(4)

${ }^{91}$ Or the 'people as Rotuma' as it is referred to.

Ibid.Chapter VI, Section 41(5)

92 Ibid.Chapter VI, Section 41(6)

${ }^{93}$ Constitution of the Republic of the Fiji Islands 1997.Chapter VI, Part 2, Section 50

${ }^{94}$ Ibid. Chapter VI, Part 2, Section 51(2)

95 Ibid. Chapter VI, Part 2, Section 51(3)

${ }^{96}$ Ibid. Chapter VI, Part 2, Section 51(4)

${ }^{97}$ Ibid. Chapter VI, Part 2, Section 51(5)
} 
down legislation proposed by the House of Representatives. ${ }^{98}$ It comprises members formally appointed by the President, but nominated from constitutional institutions and office holders, see Table 2.

Under the 1970 Constitution, the Senate had 22 seats. ${ }^{99}$ Of these eight seats were appointed by the Governor General on the advice of the Council of Chiefs; ${ }^{100}$ seven were appointed by the Governor General on the advice of the Prime Minister; ${ }^{101}$ the Governor General appointed a six members on the advice of the Leader of the Opposition; ${ }^{102}$ and one was appointed by the Governor General on the advice of the Council of Rotuma. ${ }^{103}$

Table 2: Composition of the Senate across Fiji's 1970, 1990 and 1997 Constitutions

\begin{tabular}{|l|c|c|c|c|c|c|}
\hline & \multicolumn{5}{|c|}{ Appointed by the President on the advice of the: } & President's own \\
& \cline { 2 - 5 } & $\begin{array}{c}\text { Council of } \\
\text { Chiefs }\end{array}$ & $\begin{array}{c}\text { Prime } \\
\text { Minister }\end{array}$ & $\begin{array}{c}\text { Leader of the } \\
\text { Opposition }\end{array}$ & $\begin{array}{c}\text { Council of } \\
\text { Rotumation }\end{array}$ & Total \\
\hline 1970 Constitution & 8 & 7 & 6 & 1 & - & 22 \\
\hline 1990 Constitution & 24 & - & - & 1 & 9 & 34 \\
\hline 1997 Constitution & 14 & 9 & 8 & 1 & - & 32 \\
\hline
\end{tabular}

Source: Fiji 1970 Constitution; Constitution of the Sovereign Democratic Republic of Fiji 1990; Constitution of the Republic of the Fiji Islands 1997.

Under the 1990 Constitution, the Senate's membership increased to 34. Of these 24 were appointed by the President on the advice of the Council of Chiefs and these were reserved for Pacific-Fijians; ${ }^{104}$ nine by the President, on his own judgement; ${ }^{105}$ and one, on the advice of the Council of Rotuma. ${ }^{106}$

Under the 1997 Constitution, the Senate's membership decreased to 32 seats. ${ }^{107}$ Of these 14 seats were appointed by the President on the advice on the Council of Chiefs; ${ }^{108}$ nine seats were appointed by the President on the advice of the Prime Minister; ${ }^{109}$ eight seats were appointed by the President on the advice of the Leader of the Opposition; ${ }^{110}$ and

\footnotetext{
${ }^{98}$ Fiji 1970 Constitution. Chapter V, Part 1, Section 30

99 Ibid. Chapter V, Part 1, Section 45(1)

100 Ibid. Chapter V, Part 1, Section 45(1)(a)

101 Ibid. Chapter V, Part 1, Section 45(1)(b)

102 Ibid. Chapter V, Part 1, Section 45(1)(c)

103 Ibid.Chapter V, Part 1, Section 45(1)(d)

104 Constitution of the Sovereign Democratic Republic of Fiji 1990. Chapter VI, Part 3, Section 55(1)(a)

105 Ibid. Chapter VI, Part 3, Section 55(1)(c)

106 Ibid. Chapter VI, Part 3, Section 55(1)(b)

107 Constitution of the Republic of the Fiji Islands 1997. Chapter VI, Part 2, Section 64(1)

108 Ibid. Chapter VI, Part 2, Section 64(1)(a)

${ }^{109}$ Ibid. Chapter VI, Part 2, Section 64(1)(b)

110 Ibid. Chapter VI, Part 2, Section 64(1)(c)
} 
one, on the advice of the Council of Rotuma. ${ }^{111}$

Deeper analysis of Fiji's constitutions provides further evidence as to the extent of its democratic façade. Specifically, an examination of the exclusive veto powers that the Council of Chiefs' senatorial nominees held over all legislation governing the land-tenure system highlights the true nature of Fiji's political institutions.

\section{The constitutional controls of the chiefly elite}

The Council of Chiefs was established to facilitate British colonial rule in the $19^{\text {th }}$ Century. It has held direct control of Fiji's political economy ever since. After independence, this institution has been the chiefly elite's centre of power. Provisions protecting the Council's control over the economy have been entrenched in all three constitutions, thereby limiting elected government's influence in a critical policy-making area.

The Council of Chiefs is the highest pan-Pacific-Fijian chiefly institution in Fiji.

Established by Fiji’s British Governor, Sir Arthur Hamilton Gordon, the Council was a key institution in the colonial office's system of indirect rule. The Council of Chiefs assisted in the governance of the colony, by integrating traditional authorities into the colonial administration. In the immediate period after independence, the Council of Chiefs had an ambiguous constitutional status. Used as a proxy of colonial rule, whilst Fiji was governed by Britain, independence brought to an end the very need for its existence. Nonetheless, it was recognised in the 1970 Constitution, through its powers of appointment (of constitutional positions) as a representative institution of Pacific-Fijian high chiefs. The Council existed in this representative capacity until the 1987 coup, when it, and numerous high chiefs involvement in the interim government and subsequent constitutional reform left it politicised. Under the 1990 Constitution and was formally acknowledged in the text of the 1997 Constitution. ${ }^{12}$

The Council of Chiefs was made up of 54 members. ${ }^{113}$ Each of Fiji's 14 provincial

${ }^{111}$ Ibid.Chapter VI, Part 2, Section 64(1)(d)

112 Although the literature dwells frequently on the formal recognition of the Council within the text of the 1997 Constitution itself (for example Lal, Islands of Turmoil: Elections and Politics in Fiji, p. 2.), the two preceding constitutions in fact already provided it with constitutionally recognised roles. In turn, the role attributed to it in the 1997 Constitution was no more entrenched anymore than any other institution, as is commonly claimed.

${ }^{113}$ The past tense is used in relation to the Council of Chiefs as at this time it remains a defunct body, as its membership was sacked by the interim government in 2007. 
councils has three representatives and the Council of Rotuma has two representatives on it. There are four ex-officio members: the President, the Vice-President, the Prime Minister and the Minister of Fijian Affairs, who also nominates the final six members. ${ }^{114}$ Although there is provision for provincial council representatives to be elected to the Council of Chiefs, the dominance of a traditional social hierarchy has meant that most appointees to the Council are simply the highest-ranking chiefs. Thus, a majority of the Council's members are chiefs chosen are from the hereditary chiefly elite. ${ }^{115}$

An examination of the power structures controlling Fiji's key productive resources reveals the material realities underlying its constitutional institutions. As is explained in the following section, the structure of the land-tenure system and the sinecures awarded to the chiefly elite directly reinforce the socio-political legitimacy of the elite, while providing it with unparalleled dominance within Fijian economy. The chiefly elite's vast socio-economic and political power has made the maintenance of independent electoral institutions impossible.

Alongside their economic power, the Council of Chiefs, under each of Fiji's constitutions, has advised the President on the appointment of more senatorial appointees than any other institution or office holder. ${ }^{116}$ Since the declaration of Fiji as a Republic, the Council of Chiefs has also held the power to appoint of the Vice-President and President, who have only been constitutionally responsible to the Council. ${ }^{117}$ The Council also possesses the power to remove the President and Vice-President from office. ${ }^{118}$

Under all three constitutions, the Council's senatorial nominees have effectively held a veto over legislation that might threaten "Fijian land, customs or customary rights.","119 Specifically, all three constitutions stipulated that reform of the Agricultural Landlord and Tenant Act (ALTA), the Fijian Affairs Act, the Native Lands Act and the Native Land

\footnotetext{
${ }^{114}$ Robert Norton, "The Great Council of Chiefs in Fiji's Era of Crisis and Reform," in 1987: Fiji Twenty Years On, ed. Brij V. Lal, Ganesh Chand, and Vijay Naidu (Lautoka: Fiji Institute of Applied Studies, 2008), p. 116.

115 Ibid.

116 Eight under the 1970 Constitution, 24 under the 1990 Constitution, and 14 under the 1997 Constitution.

117 Although the Council of Chiefs is obliged to consult with the Prime Minister regarding the appointment of the President or Vice-President, it acts on its own voliton. Constitution of the Sovereign Democratic Republic of Fiji 1990. Chapter V, Section 31

118 As with the process of appointment of the President, although the Council of Chiefs is obliged to consult with the Prime Minister if it wishes to remove the President or Vice-President, it acts on its own voliton. Constitution of the Republic of the Fiji Islands 1997. Section 93(3)(f)

119 Fiji 1970 Constitution. Chapter V, Part 4, Section 67(1) and Section 68(2)
} 
Trust Act (NLTA), ${ }^{120}$ could not be undertaken without a majority ${ }^{121}$ of support at the third reading of Senators appointed by the President on the advice of the Council. ${ }^{122}$

These constitutional provisions have entrenched the system of land tenure, distribution of lease rents and structure of lease agreements in Fiji's economy. They have also provided the chiefly elite with exclusive control of this section of the economy and the resources extracted from it. This has entrenched the Council as the highest political authority within the Fijian polity, effectively making the Council of Chiefs a parallel - and often superior authority to the legislative and executive bodies.

For political institutions to be democratic, electoral institutions must determine the composition of the offices that possess sovereignty. Importantly, as Schumpeter and Przeworksi's definitions demand, their decision-making must not be greatly inhibited by unelected powers. The presence of constitutional offices and processes has created the illusion that Fiji's electoral institutions have exercised unchallenged sovereignty. In each of Fiji's constitutions, the Council of Chiefs has held direct influence over the composition of the institutions in which sovereignty is embedded. Although Fiji has had a written constitution, maintained electoral institutions and observed the rule of law, an unelected chiefly elite has maintained it ability to usurp government. As is demonstrated in the following chapters, when electoral results handed government to chiefly-backed parties, electoral institutions were sustainable. Yet, when non-chiefly backed parties attained government, the elite overthrew the electoral institutions and usurped the government.

Fiji has never been a democracy. The authoritarian elite that overthrew the LabourNational Federation government in 1987, and then the Labour-led government in 2000,

120 The importance of these Acts in the structure of the Fijian economy, and the power of the chiefly elite, is detailed in the following section.

${ }^{121}$ Notably the power of the Council of Chiefs is explicitly described as "veto power of certain members". The 1970 Constitution states that the support of six of the eight Senators is needed to alter Section 45(1)(a). Fiji 1970 Constitution. Chapter V, Part 4, Section 67(1). The 1990 Constitution states that the support of 18 of the 24 Senators is needed to alter this legislation. Constitution of the Sovereign Democratic Republic of Fiji 1990. Chapter VI, Sections 77(7) and 78(1). The 1997 Constitution states that the support of nine of the 14 Senators is needed to alter this legislation. Constitution of the Republic of the Fiji Islands 1997. Chapter XV, Sections 185 (1)(k), 185(2)(b)(ii) and 192(4).

122 This clause is almost identical across each of Fiji's constitutions. Constitution of the Republic of the Fiji Islands 1997. Section 68(2) lists the Acts protected by this clause: (a) the Fijian Affairs Act; (b) the Fijian Development Fund Act; (c) the Native Lands Act; (d) the Native Land Trust Act; (e) the Rotuma Act; (f) the Rotuma Lands Act; (g) the Agricultural Landlord and Tenant Act; (h) the Banaban Lands Act; or (i) the Banaban Settlement Act.

Fiji 1970 Constitution. Chapter V, Part 4, Sections 67(1), and 68(2). 
was never subordinate to electoral processes. The chiefly elite has held power outside Fiji's electoral institutions even as they were written into its constitution.

\section{How an authoritarian chiefly elite governs the economy}

The Pacific-Fijian chiefly elite exerts influence over Fijian society through its management of the illiberal land-tenure system, which provides it economic and political dominance over Fijian society. As well as management of the land-tenure system, chiefs' extensive influence over the productive resources of the Fijian economy have been separated from parliamentary decision-making. Chiefly control over the utilisation of native land, the price of lease rents and the distribution of those rents has provided chiefs with the political and material advantages necessary to suppress any challenges to their authority. In managing native land, the NLTB has served as an economic proxy for the Council of Chiefs. This land-tenure system and its lease-rents has been, in part, maintained through excess earnings in the sugar industry that are made possible by subsidy payments from the EU.

Vesting control over the vast majority of land in the highest chiefs has given them motive and capacity to suppress electoral processes at their will. Under the claim of preserving traditional elements of Pacific-Fijian culture, this authoritarian elite has suppressed liberties and prosperity for both Indo-Fijians and Pacific-Fijians commoners.

This section comprises of four parts. It demonstrates how the management of native land and the distribution of lease rents directly support the authoritarian chiefly elite. First, it investigates how native land was removed from the market and put under the control of chiefly elites. It explains the two lease-tenure agreements, and the manipulation of native land valuations and lease rents. Second, it compares the productivity of Fiji's sugar industries with other Sugar Protocol recipients, and explains how the Sugar Protocol subsidy payment has helped maintain Fiji's systems of native land tenure, land valuation and lease-rent determination. Third, it examines how lease rents are distributed within the "proprietary unit," 123 and the influence this distribution mechanism has on communal

${ }^{123}$ Landowning units are referred to in legislation as proprietary units. 
hierarchical structures. Finally, it examines how the NLTB receives poundage ${ }^{124}$ for its management of native land, and how the NLTB is an unaccountable, unchecked economic proxy for the Council.

\section{The legal status of land and the maintenance of the pre-colonial social hierarchy}

Pacific-Fijian tribal social hierarchy has been perpetuated by institutional advantages that were established as mechanisms of colonial rule. The British colonial administration used pre-existing hierarchies to facilitate and maintain control over its colonies. In the case of Fiji, this led to the establishment of the Council of Chiefs in 1874, a body that housed the highest, vanua chiefs. ${ }^{125}$ The native land-tenure system and institutions such as the Council of Chiefs were designed and entrenched by the colonial authority to facilitate peaceful colonial rule. Importantly these policies of indirect rule also influenced the charter of land in Fiji. Through the registration of native land, colonial administration vested control and determination of lease rents in the chiefly-controlled social unit mataqali. This assisted in the management of the Pacific-Fijian population. Fiji's colonial history was founded on a reciprocal relationship between colonial authorities and high chiefs: where the Colonial Office entrenched chiefs' control over commoners through patronage, and chiefs ensured this hierarchy translated to the subordination of Pacific-Fijians to colonial rule.

Through the registration of native land proprietary units, the colonial administration perpetuated the maintenance of the "pre-colonial" ${ }^{126}$ Pacific-Fijian hierarchy. Despite the corrosive presence of urbanisation and modernisation, Pacific-Fijian social hierarchy still rests on this pre-colonial chiefly system. The sediments of colonialism lie deep within Pacific-Fijian society; with the entrenchment of pre-colonial tribal and sub-tribal levels of hierarchy in the land-tenure, system has perpetuated the sustenance of this social order. ${ }^{127}$

Land in Fiji exists in one of three legal states: freehold land, state land and native land.

\footnotetext{
${ }^{124}$ Poundage is a term used for payments by the NLTB for the maintenance of the native land lease system.

125 Simione Durutalo, "The Fiji Trade Union Movement at the Crossroads: Social and Political Options for the Labour Movement," in Fiji Trade Union Council Workshop on Social and Political Options for the Labour Movement in Fiji (Suva1985), p. 18.

126 The assertion that the social structure maintained within the land tenure system has been a 'pre-colonial' one is contentious.

${ }^{127}$ Durutalo, "The Fiji Trade Union Movement at the Crossroads: Social and Political Options for the Labour Movement," p. 17.
} 
Governor Sir Hercules Robinson's first proclamation following the Deed of Cession in 1874 prohibited all land that had not been 'sold' previously ${ }^{128}$ from future legal exchange. ${ }^{129}$ This decree, formalised by Governor Gordon's 1875 Native Land Ordinance, stipulated that: "All conveyances, transfers, leases, and all transactions whatsoever in land or relating to any interest between Natives and any persons not being Natives are hereby expressly prohibited and declared to be invalid and it shall not be lawful to institute any proceedings whatever in any Court of Law in respect thereof." ${ }^{\prime 30}$

Since the Native Land Ordinance native land has existed as an untradeable asset. ${ }^{131}$ Original registration of native land recorded it at $82 \%$ of total land in Fiji. Native land now encompasses $87 \%$ of all land in Fiji. ${ }^{132}$ Freehold land comprises $8 \%$ of total land and is as a tradable asset. This was land sold by chiefs or the crown, or simply claimed by settlers, before the decree alienating it from the market. ${ }^{133}$ State land comprises $4 \%$ of total land. ${ }^{134}$ Before the declaration of a Republic in 1987, this land was called 'Crown' land. State land is the remnant of that land taken by the British colonial administration.

Under the Native Land Act, ${ }^{135}$ the composition of proprietary units, ${ }^{136}$ the specific family unit or individual that are the registered land owners of any unit of land can vary according to "custom and tradition" within tribal units. ${ }^{137}$ The ownership is predominantly collective, with mataqali holding the majority of native land titles. Other tribal units holding proprietary titles over native land include the tokatoka or family unit, ${ }^{138}$ the yavusa or tribe,

128 'Sold' land was determined to be any that had been traded through legal or financial transaction by PacificFijians, predominantly chiefs, to Europeans.

${ }^{129}$ Fiji To-Day by M.A.T.E. (Sydney: Geo. Robertson \& Co. , 361 George Street, 1886), p. 29.

130 Native Lands Ordinance 1875. Section II

${ }^{131}$ Exception can be made for the transfer of title to the State, with consent of the NLTB, however, this rarely happens.

After independence this status has been governed under Native Land Trust Act 1970, Legal Notice 112 of 1970. Section 5(1)

132 The increase is been due to the sale of crown and state land to Pacific-Fijian communities.

There are inconsistent figures surrounding the total proportion of native land in Fiji. These range from $82 \%$ to $90 \%$. I will use the figure stipulated by the NLTB, $87 \%$, as it is the legal manager of that land. Native Land Trust Board, "Native Land Trust Board Website," http://www.nltb.com.fj.

${ }^{133}$ France, The Charter of Land: Custom and Colonization in Fiji pp. 46-54.

134 Totals of freehold and state land vary. Many texts estimate the proportions at $6 \%$ for each, however, the NLTB states $8 \%$ of land is freehold and $4 \%$ is state. Because the NLTB is the authority on land management, I will use its statistics. Native Land Trust Board, "Investing." http://nltb.com.fj/investing.html (accessed 12 March 2009)

135 Native Lands Act 1905.

136 Proprietary units are the legal land owning units of native land.

137 Native Lands Act 1905. Section 3

In practice this difference was a product of the Native Lands Commissions variance in determining its allocation of native land.

138 This ownership structure is predominantly used in the province $\mathrm{Ba}$. 
or several yavusa collectively (see Figure 1). ${ }^{139}$ Some individuals hold proprietary titles over native land. These are predominantly title heads of tribal units ${ }^{140}$ or agnate descendants of high chiefs. ${ }^{141}$

The process of registration of land during early colonial rule was highly political and contentious. After taking office in 1875, Governor Gordon was instructed by the British Secretary of State to construct a system of land administration to govern land alienated from the market by the Native Land Ordinance. Gordon outlined that the native landtenure system should reflect its immemorial origin and customary state. This was in accordance with Gordon's policy of retaining "indigenous [social] institutions" and his determination that this pre-existing system, "should be expounded, recorded and preserved." ${ }^{142}$ Following this, the Native Lands Commission travelled Fiji recording the hierarchical structure of each mataqali or tokatoka ${ }^{143}$ and individual mataqali and tokatoka's claims to ownership of native land. To obtain property rights mataqali and tokatoka had to lay claim to land and demonstrate their habitual use of it. Where this was not done, land was then recorded as belonging to the crown. ${ }^{144}$

In his text Vaka I Taukei: The Fijian Way of Life, ${ }^{145}$ Asesela Ravuvu presents Figure 1 as the depiction of the "classical [Pacific-] Fijian social structure." ${ }^{\text {146 }}$ The Pacific-Fijian social structure is described as encompassing three hierarchical levels derived he pre-colonial chiefly system: the vanua, yavusa and mataqali. Vanua is the largest unit, which encompasses yavusa and mataqali. Yavusa are the middle level unit, which encompass mataqali.

139 Native Land Trust Act 1970. Section 2

${ }^{140}$ Chiefs who hold the hereditary title of Ka Levu.

${ }^{141}$ Chiefs who hold the hereditary title Qele Ni Kawa, inherited through the paternal lineage. Native Land Trust Board, "Ownership Structure." http://nltb.com.fj/land_ownership.html (accessed 12 March 2009)

142 France, The Charter of Land: Custom and Colonization in Fiji p. 110.

143 This concerned the parallel and vertical structure of each tribes and sub-tribe.

144 This is taken from an extract from the opening address of Sir Bickham Escott to the Council of Chiefs on 20 May 1914 France, The Charter of Land: Custom and Colonization in Fiji p. 177-78.

Peter France has cited the difficulty and inaccuracy of this process undertaken by the Native Lands Commission. The inacurracy of mythical theory and oral histories is uncertain and made less credible by the consumption of kava, a Fijian narcotic, during the processes. —- The Charter of Land: Custom and Colonization in Fiji p. 10.

145 Asesela Ravuvu, Vaka I Taukei: The Fijian Way of Life (Suva: Institute of Pacific Studies, University of the South Pacific, 1983).

146 Ibid., p. 77. 
Figure 1: Maxwell's depiction of Fiji's pre-colonial social structure

\begin{tabular}{|c|c|c|c|}
\hline \multicolumn{2}{c}{ Tribe } \\
\hline Clan \\
Sub-Clan or Lineage
\end{tabular}

Source: Peter France, The Charter of Land: Custom and Colonization in Fiji (Melbourne: Oxford University Press, 1969), p. 165-75.

This depiction of pre-colonial Pacific-Fijian social structure is highly simplistic and somewhat inaccurate. Rather, Figure 1 is merely the depiction drawn in 1913 by G. V. Maxwell, ${ }^{147}$ an administrative officer in the colonial government. After less than six months of field investigations and recording evidence, Maxwell produced a depiction that has formed the definitive interpretation of Pacific-Fijian social structure in Fiji. Maxwell's diagram, presented to the Legislative Council in $1914,{ }^{148}$ provided the Colonial Office with an orthodox ${ }^{149}$ interpretation of Fijian hierarchical and tribal structures, and served as the basis of all subsequent investigations of the Native Lands Commission. Maxwell's diagram was used as the framework upon which the land-tenure system was based, although it is nothing more than an abstraction of a complex system by a colonial official. As is explained later in the chapter, this diagram became the structure according to which all native land lease rental income has been distributed. From this diagram, colonial authorities also determined the amount of rent due to Pacific-Fijian chiefs to guarantee their adherence to and cooperation with colonial governance. The simplicity of Maxwell's interpretation is concerning given its impact on political and economic structures within Fijian society, and given its maintenance until the present, the longevity of the diagram.

Peter France ${ }^{150}$ has stated that the diagram drawn by Maxwell in 1913 (Figure 1) was solely Maxwell's basic interpretation of Pacific-Fijian tribal hierarchy. In commenting on

\footnotetext{
147 Maxwell was chosen by Governor May to complete the task of registering all native land.

148 Colonial Office of Fiji, "Legislative Council Paper No. 27 of 1914," (1914). Cited in France, The Charter of Land: Custom and Colonization in Fiji p. 166.

${ }^{149}$ France discusses the importance of establishing an orthodox model of pre-colonial Fijian hierarchy. This concerned the simplicity of the model drawn by Maxwell, providing the Colonial Office a uniform model through which it could interpret chiefly hierarchy and interact with Pacific-Fijians. France, The Charter of Land: Custom and Colonization in Fiji pp. 102-76.

${ }^{150}$ France's text 'The Charter of Land: Custom and Colonization in Fiji' is seen as the authoritative text on early colonial interaction in Fiji and the commodification of land.
} 
Maxwell's reports that demonstrate the difficulties of his fieldwork, France argues that given the circumstances of Maxwell's investigation, it is hard to comprehend that sufficiently reliable evidence was obtained to produce a comprehensive report and to substantiate his constructions. ${ }^{151}$ Notably, although Maxwell was instructed to objectively observe and record the customary Pacific-Fijian tribal structure, the chiefs exerted significant influence over his investigations. The 1892 Native Land Ordinance enshrined the position of mataqali as the proprietary unit and thus, as landowner. This stemmed from a Council of Chiefs decision in 1879, decreeing mataqali as the proprietary unit of all native land. ${ }^{152}$

During Maxwell's investigations, and as happened with the Council of Chiefs 1879 decision, chiefs sought to ensure all land was recorded as being held by mataqali. As at this hierarchical level it provided chiefs control over the proprietary title and, thus, control over the land. In 1915, subsequent to the presentation of his report to the Legislative Council, Maxwell reported to the Colonial Office his original observation, affirming the Council of Chiefs 1879 decision, that mataqali were the pre-colonial customary proprietors, was incorrect. Rather, Maxwell informed the Colonial Office that the tokatoka, the tribal unit below the mataqali, was in fact predominantly the customary proprietor. The Colonial Office informed Maxwell that it had no interest in recording any variance from mataqali across the composition of proprietary units, as doing so would provoke conflict with the Council of Chiefs who had determined that mataqali would be the proprietors, as was stipulated in the NLO. ${ }^{153}$ In 1917, after years of uncertainty, Maxwell conceded that the Native Lands Commission would restrict the recording of proprietary units to mataqali and the existence of any 'special interests'. ${ }^{154}$

In regard the registration of native land, the influence of the chiefs over proceedings cannot be underestimated. Where mataqali were registered as proprietors, chiefs' were granted exclusive control over the unit of land. Where tokatoka were registered as proprietors, chiefs lost direct control over the unit of land because the heads of tokatoka do not have chiefly title. Maxwell himself observed the chiefs desire to manipulate the registration of land during his fieldwork in 1915. He observed, "It must not be supposed that the natives (Pacific-Fijians) welcome the Commission [led by Maxwell]. They know

\footnotetext{
${ }^{151}$ France, The Charter of Land: Custom and Colonization in Fiji pp. 166-69.

152 Ibid., p. 170.

153 Ibid., pp. 170-71.

154 Ibid., p. 173.
} 
that they have much to lose and nothing to gain if the truth comes out and they resort to every possible means to conceal the truth." ${ }^{, 155}$ Maxwell, had undertaken his investigations much like anthropologist, naively assuming he could observe the tribal hierarchy in its customary state, without the realising the impact the chiefs' awareness of the importance of his work would have on what he observed. As they had done in 1879, high chiefs were well aware of the implications and importance of land registration. Form the 1915 affirmation of the original (1879) determination of land ownership, the chiefs had once again dictated reality to the Colonial Office for their own benefit. Mataqali chiefs ${ }^{156}$ direct control of land is remains today, and the legislation governing this stipulates that these chiefs are the sole determinants of how lease rental incomes are distributed.

The contention that the registration of 'native land' simply transferred the pre-colonial state of land in Fiji from its immemorial state to Western legal recognition and to formalised ownership has been disputed. Lorimer Fison ${ }^{157}$ argued at a public lecture in Levuka $^{158}$ in April 1880 that because all land in Fiji was traditionally owned collectively by social unit, all land was, according to the immemorial Pacific-Fijian customs, inalienable from the market. ${ }^{159}$ As explained earlier, the Council of Chiefs decision in 1879 had determined all native land was to be vested in the control of the turaga ${ }^{160}$ mataqali as the proprietors. France argues that this transfer of title from common ownership to chiefly ownership was able to take place because common Pacific-Fijians were oblivious to it. Their customs and appreciation of hierarchy had itself been corrupted by chiefly elites. ${ }^{161}$ Arguing chiefly control over the registration of native land, Fison stated: "The chief is not their lord, but he is their landlord. He is but one of the joint tribal owners together with themselves. As a member of a landowning tribe, he has his own share of the tribal land; and, as far as rightful ownership of the soil is concerned, he has not one acre more."162 Despite Fison's objections, registration proceeded and by the early 1920s, most native land was registered predominantly with mataqali as the propitiators.

\footnotetext{
155 Ibid., p. 167.

156 Or turaga

${ }^{157}$ Fison was an anthropologist and a graduate of the University of Melbourne. He was in Fiji in the late $19^{\text {th }}$ Century, with the Wesleyan Methodist Mission.

${ }^{158}$ Levuka was Fiji's first colonial capital.

${ }^{159}$ France, The Charter of Land: Custom and Colonization in Fiji pp. 117-18.

160 Turaga is the individual, usually a chief, in which the proprietary unit of native land is vested.

${ }^{161}$ France, The Charter of Land: Custom and Colonization in Fiji p. 119.

${ }^{162}$ Lorimer Fison, Land Tenure in Fiji (London: Harrison, 1881), p. 13. cited in France, The Charter of Land: Custom and Colonization in Fiji p. 119.
} 
The process of land registration in Fiji between the alienation of native land in 1874 and the Council of Chiefs' recommendation to register all land under mataqali fundamentally restructured Fijian society. Whereas colonial authorities thought the registration of land was merely a legal formalisation of a pre-existing social system, the codification of native land was more akin to the British enclosures movement. Polanyi has described the enclosures transfer of common land to private ownership as "virtually a revolution of the rich [elite] against the poor [masses]" where the elite "were robbing the poor of their share in the common." ${ }^{, 163}$ In Fiji, as in Britain, land was transferred from common ownership to private ownership, with the determination of the land's use and control of its lease rents vested in the control of chiefly elites.

As demonstrated by Ravuvu's presentation of the "classical [Pacific-] Fijian social structure", there is much confusion surrounding the traditional status of the pre-colonial social structure and the Council of Chiefs. Simione Durutalo ${ }^{164}$ noted, that the vast majority of Pacific-Fijians believe that Fiji's native land-tenure system is purely a 'traditional' one and that the Council of Chiefs is a 'traditional' institution. ${ }^{165}$ Since independence, chiefs have claimed that the Council is the representative institution for the Pacific-Fijian community and that the socio-economic advantages provided to chiefs are necessary to maintain the Pacific-Fijian culture. Indeed, chiefs' material advantages institutionalised with the distribution of native land lease rents has served an important role in perpetuating this social hierarchy. A clear example of this was an assertion by the Alliance Party Deputy Prime Minister, Ratu David Tognivalu, during the 1987 election campaign, saying that

"All land in Fiji was threatened by the Fiji Labour Party, and... [it] wanted to remove the chiefs from politics. This will destroy the inseparable link between the turaga and the vanua ${ }^{166} \ldots$ The turaga and the vanua are one - one could not exist without the other - the chiefs were a bulwark of security for all and custodians of Fijian identity, land and culture...to

\footnotetext{
163 Karl Polanyi, The Great Transformation: The Political and Economic Origins of Our Time (Boston: Beacon Press, 1957), p. 37.

${ }^{164}$ Ratu Simione Durutalo was a Pacific-Fijian political scientist based at the University of the South Pacific. He was also the founding Vice-President of the Fijian Labour Party in 1986.

165 Durutalo, "The Fiji Trade Union Movement at the Crossroads: Social and Political Options for the Labour Movement," p. 17.

166 In this context vanua is taken to mean land.
} 
remove chiefs would pave the way for instability." 167

Here, Ron Crocombe's ${ }^{168}$ observation is apt “...many do not realise that what they believe to be their ancient heritage is in fact a colonial legacy." 169

Within pre-colonial Fiji, social hierarchy prescribing chiefly hierarchy was maintained for social cohesion and survival. ${ }^{170}$ Under colonial rule, and since independence, however, the maintenance of the hierarchy is directly linked to the mechanism facilitating the distribution of rents down the chiefly hierarchy. The filtering of rents down the social hierarchy and the ability of the turaga to distribute revenues amongst the individuals in the proprietary unit, incentivises observing and maintaining this pre-colonial social hierarchy. In absence of the EU sugar subsidies there would be no excess earnings to meet inflated rents charges. In the absence of the inflated rent earnings and the patronage flowing from them, there would be less motivation to maintain this hierarchy and less incentive to observe a hereditary authoritarian hierarchy against the challenges of modernisation.

The system of inflated land valuations and the distribution of lease rents have been supported by the presence of inflated export earnings in the sugar industry. ${ }^{171}$ Through the chiefs' monopoly over native land and their arbitrary control over native land valuation, they have been able to charge inflated rents that are a product of the exclusion of native land from the market. Where highly inflated rents would have otherwise been unsustainable, the subsidies Fiji's receives under the EU's Sugar Protocol provides it with export earnings far above world market prices. This provided the excess to satisfy the financial demands of less efficient sugar production in Fiji and support chiefs' patronage.

167 Lawson, The Failure of Democratic Politics in Fiji, pp. 242-43.

168 Ron Crocombe is Emeritus Professor of Pacific Studies at the University of the South Pacific.

${ }^{169}$ Durutalo, "The Fiji Trade Union Movement at the Crossroads: Social and Political Options for the Labour Movement," p. 17.

170 Ravuvu, Vaka I Taukei: The Fijian Way of Life.

171 Tourism is frequently referred to as Fiji's largest industry, although this has been dependent on political situations. Native land leases to tourism operations are charged out at exorbitant prices, as provided for under the Native Land Trust Act. The lack of empirical data on tourism lease rents makes comparisons with the sugar industry difficult, hence I will focus predominantly on the role of the sugar industry in maintaining exuberant land valuations. 


\section{Lease agreements \& land valuations}

The alienation of native land from the market, and the conflicts between the two lease agreements makes the construction of land valuations a highly political process and subject to manipulation. ${ }^{172}$ The removal of native land from the market makes the construction of "fair" or "market" values of land and the rents in lease agreements problematic. The management of all native land rests with the NLTB "for the benefit of the [Pacific-] Fijian owners." ${ }^{173}$ Through its influence over the NLTB's Board of Trustees, ${ }^{174}$ the Council of Chiefs controls the determination of land values and lease rents.

Native land lease agreements exist in two forms and are governed by two pieces of legislation: the 1970 NLTA, which governs non-agricultural leases, and the 1976 ALTA, which governs agricultural leases. This differentiation between agricultural and nonagricultural leases arose with the issuance of the 1966 Agricultural Landlord and Tenant Ordinance (ALTO). The following chapter examines the differences between the lease agreements and the politics surrounding the formalisation of the ALTO into an act of parliament. Before the issuing of the ALTO, all native land lease agreements were governed under the 1940 Native Land Trust Ordinance (NLTO). Agricultural land leases are defined as those encompassing land "used predominantly for the growing of crops, dairy farming, fruit farming, forestry, horticulture, bee keeping, poultry keeping or breeding and rearing or keeping of livestock." 175 All sugar leases are therefore governed as agricultural leases. Nonagricultural land encompasses all land not under the terms listed above. The Department of Lands zones land in Fiji, which then determines the applied land lease agreement. Before the issuing of the ALTO, all native land lease agreements were governed under the 1940 Native Land Trust Ordinance (NLTO).

The ALTA and the NLTA formulated rents in very different ways; though these inevitably intertwined. Under the NLTA, non-agricultural native land leases require annual rental and a premium 'goodwill' payment to secure the lease. These both have no fixed value and are

172 I will focus on the position of native land within the economy due to its high proportion of total land $(87 \%)$. Academic scholarship has focused of Fiji's economy and land tenure focuses near exclusively on native land.

173 Native Land Trust Board, "Vanua: Native Land Trust Board Review 1969-1974 " (Suva: Native Land Trust Board, 1974), p. i.; Native Land Trust Ordinance 1940. Section 4(i); Native Land Trust Act 1970. Section 4(1). ${ }^{174}$ Note the Native Land Trust Board (NLTB) is an institution encompassing both the Board of Trustees of the NLTB and the management of the NLTB. I will use these terms to distinguish where responsibility lies for actions under taken on behalf of the NLTB.

175 Agricultural Landlord and Tenant Act 1976. Part 1, Section 2 
charged at 'market' rates, as determined by the NLTB. ${ }^{176}$ Under the NLTA, the NLTB determines non-agricultural lease rents on a case-by-case basis, providing chiefly elites with direct control over the value of non-agricultural lease rents. ${ }^{177}$ Under the ALTA, no premium is paid, and lease rents are set using a formula: 6\% per year of the Unimproved Capital Value (UCV) of the native land unit. ${ }^{178}$ Before the issuing of the ALTO, native land units had no formal value, as they were all determined on a case-by-case basis by the NLTB. When the ALTO was issued, all agricultural lease units were given a valuation through the setting of first UCVs. The UCV of land units are set by a Committee of Valuers, who sit at the request of the Minister of Lands, generally every five years. ${ }^{179}$ There is not UCV valuation for all native land units, only those that are leased under the ALTA.

\section{The problematic and political nature of valuating native land}

The peculiar nature of Fiji's land-tenure system causes inflation of both ALTA and NLTA native land leases rents. Because $93 \%$ of land is alienated from sale $(87 \%$ is native land and $6 \%$ state held land), market valuations for the freehold land are highly inflated. Despite native land being alienated from the market, its valuations are regularly calculated in direct relation to the valuation of comparable freehold land. Clearly, attaching the value of a scare resource to one that is relatively abundant results in prices that are much higher than would be expected in a truly open market. What is more, the value of native land takes into account only the freehold land sold in the year of evaluation. The high quality, prime location and infrequency of sale of freehold land only further inflates its vales; and by extension that of native land. The Committee of Valuers has tried to link the UCV to the output of the industry using the land, but the vast variations in production levels has made

176 Native Land Trust Act 1970. Part 2, Section 13

177 The NLTA lease terms, including rent and premium values are negotiated between parties and overseen by the NLTB management. The NLTB Board must approve all of the NLTA leases, providing the Council with tight control over all native land leases and the value of rents and premiums.

178 Agricultural Landlord and Tenant Act 1976. Part II, Section 14(1)

${ }^{179}$ The Committee of Valuers is appointed by the Minister of Lands and comprises of: a NLTB land valuer, a public sector land valuer, a private practice land valuer and a chairman with knowledge in agricultural matters. The first UCV valuations were stipulated in the 1976 Agricultural Landlord and Tenant Act (ALTA) itself. The Committee of Valuers is meant to sit every five years, but this is dependent on Ministerial discretion. Subsequently, the Committees have sat in 1982, 1987 and 1992, producing Agricultural Land (Declarations of Unimproved Capital Values) Orders at each sitting. Lands Department, "Agricultural Landlord and Tenant Act (Chapter 270) - Agricultural Land (Declaration of Unimproved Capital Values) Order - 1987, Legal Notice No. 67 of 1987," (Suva: Fiji Government Printer, 1987).; __ , "Agricultural Landlord and Tenant Act (Chapter 270) - Agricultural Land (Declaration of Unimproved Capital Values) Order - 1992, Legal Notice No. 127 of 1992," (Suva: Fiji Government Printer, 1992).; —_, "Agricultural Landlord and Tenant Act (Chapter 270) - Agricultural Land (Declaration of Unimproved Capital Values) Order - 1997, Legal Notice No. 104 of 1997," (Suva: Fiji Government Printer, 1997). 
this problematic. ${ }^{180}$ In its formulation of 'market' value lease rents, the NLTB uses UCV only as the bare minimum land.

There are also major problems in the process of UCV setting. While, provision is made for different classes and quality of land, quality it does not differentiate land according to geographic location, or other important factors such as access to transport, major urban centres or markets for goods and services. ${ }^{181}$

Figure 2: Rent per hectare for agricultural lease agreements in Fiji across ethnic groups in $1990^{182}$

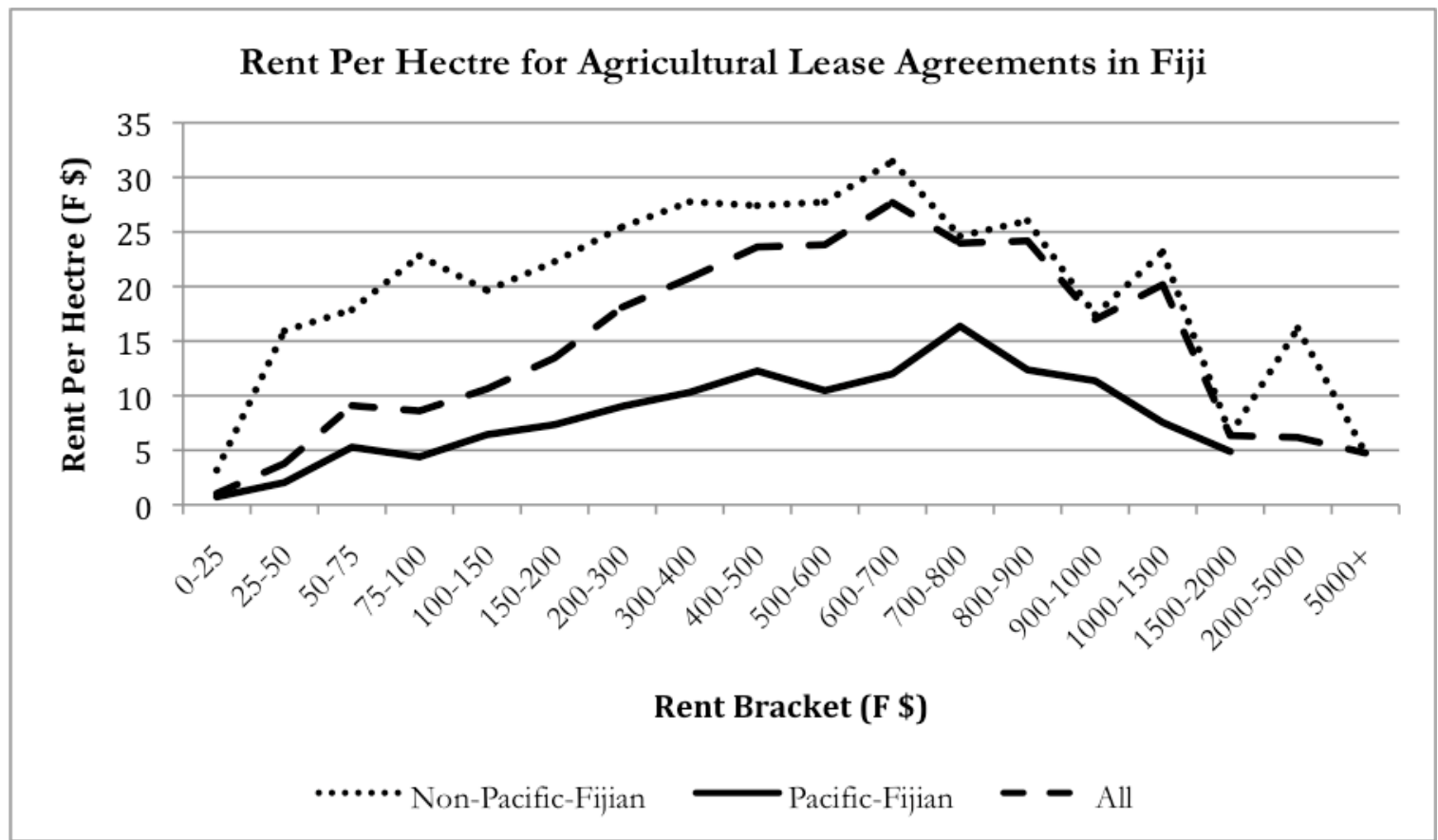

Source: Biman C. Prasad, "Property Rights, Economic Performance and the Environment in Fiji: A Study Focusing on Sugar, Tourism and Forestry - Unpublished Ph.D Dissertation" (University of Queensland, 1998).

Although the ALTA lease rents have a fixed lease value, the NLTB has been inconsistent in the way it applies this to specific lease agreements. For example, Figure 2 displays the range of agricultural lease agreements held by individuals in different ethnic groupings for the

${ }^{180}$ Lands Department, "Agricultural Landlord and Tenant Act (Chapter 270) - Agricultural Land (Declaration of Unimproved Capital Values) Order - 1987, Legal Notice No. 67 of 1987," p. 214-25.

181 Biman C. Prasad, "Property Rights, Economic Performance and the Environment in Fiji: A Study Focusing on Sugar, Tourism and Forestry - Unpublished Ph.D Dissertation" (University of Queensland, 1998), p. 93.

182 Within this figure the term "non-Pacific-Fijians" is used by the NLTB. This terms refers almost exclusively to represent Indo-Fijian leases. 
year $1990 .{ }^{183}$ This diagram shows that Indo-Fijians pay significantly more rent per hectare than Pacific-Fijian. Although Pacific-Fijians have tended to lease land of a lower quality, and pay lower rents as a result, the disparity between lease rents paid by Pacific-Fijian and Indo-Fijians is dramatic. This evidence suggests that even under the seemingly fixed ALTA lease rents, the NLTB has artificially lowered lease rents for Pacific-Fijians. ${ }^{184}$

The NLTB's Board of Trustees ultimate discretion over both lease rents and premium payment determination is problematic. As explained later in this chapter, the NLTB's Board is almost exclusively comprised of high chiefs. Furthermore, chiefs' have a vested interest, as institutionalised recipients of native land lease rents, in ensuring native land lease rents are charged at the highest possible value. Thus, their ability to determine market or fair rents for non-agricultural leases is compromised. In addition, the NLTB not only possesses a monopoly over rent setting of NLTA leases and the application of ALTA leases, but also over the knowledge of what NLTA lease rents are worth. This chapter goes on to show that the NLTB has systematically constructed its own accounting standards that do not require it make public both its applied value of native land and the lease rents it charges. The absence of this knowledge serves to further strengthen the NLTB's control over lease rent determination.

As the monopoly supplier of lease land, the NLTB does not set lease rents at a value comparable to the equilibrium between supply and demand. Rather, it has the ability to set them at a rate between the extremity of the chiefs' demands for high rents and the rate at which leaseholders can sustain sufficient profit to maintain production and not abandon their lease. Therefore, dependent on native land for production are forced to pay exorbitant rents, which acts as a weight on their competitiveness with industries in comparable economies further decreasing Fijian industries comparative advantage.

The presence of a uniform lease rent in ALTA, and relatively equitable earnings for a sector of leaseholders in the sugar industry, provided by the EU's Sugar Protocol subsidy payment, make analysis of the structures of inflated agricultural lease rents possible. ${ }^{185}$ As

\footnotetext{
183 The data displayed in Figure 2 is the best of very little data available on land lease valuations available in the public domain.

184 Prasad, "Property Rights, Economic Performance and the Environment in Fiji: A Study Focusing on Sugar, Tourism and Forestry - Unpublished Ph.D Dissertation", p. 62.

185 As mentioned in Chapter Two the decentralised and private nature of tourism lease agreements makes it difficult to examine their role in inflating lease rents.
} 
will be explained in the following section, these inflated ALTA land lease rents have in part been sustained by the subsidies the Fijian sugar industry has received as a recipient of the EU's the Sugar Protocol.

\section{The role of EU sugar subsidies in sustaining inflated lease rents}

Fiji's sugar industry, as a recipient of the EU's Sugar Protocol quotas and subsidy payments has earned far above what it would have earned at world market rates. These subsidies have buffered the illiberal institutions within the industry from market realities. The centrality of sugar industry within Fiji's economy, the common structure of agricultural lease rents and farmers' relatively equitable earnings make the sugar industry a suitable example to demonstrate how inflated lease rents have been sustained.

The sugar industry and Fiji's racial divisions are intimately intertwined, as both are remnants of colonial governance. British colonial administrators brought Indians to Fiji as indentured labourers, to grow sugar as a cash crop for the British Empire. This system of labour continued until 1920. Following their release from indenture, Indo-Fijian farmers leased land from landowners, of which they predominantly used for sugar farming.

\section{The Fijian sugar industry}

Historically sugar production has been Fiji's leading industry ${ }^{186}$ and retains a significant position within the Fijian economy. It is estimated that up to 40,000 people are directly employed in the sugar industry, amounting to $25 \%$ of Fiji's labour force, ${ }^{187}$ and up to 250,000 people are indirectly dependent on the industry for their livelihoods, many of these being native land owners. ${ }^{188}$ The sugar industry is Fiji's main commodity earner bringing in US\$230-240 million a year, ${ }^{189}$ amounting to $22 \%$ of foreign exchange earnings annually and amounting to between $7 \%$ and $11 \%$ of gross domestic product. ${ }^{190}$

186 Although in recent years, with the non-renewal of ALTA leases (see discussion in chapter five) declining sugar production has led to tourism surpassing it. Paresh Kumar Narayan and Biman C. Prasad,

"Economic Importance of the Sugar Industry in Fiji: Stimulating the Impact of a 30\% Decline in Sugar Production," in Working Paper No. 2004/12, July 2004 (Suva: Department of Economics, University of the South Pacific, 2004), p. 2.

${ }^{187}$ Fiji Sugar Corporation, "The Fiji Sugar Industry," Fijian Studies 1, no. 2 (2003): p. 318.

188 Paresh Kumar Narayan and Biman C. Prasad, "Fiji's Sugar, Tourism and Garment Industries: A Survey of Performance, Problems and Potentials " Fijian Studies 1, no. 1 (2003): p. 17.

189 "US\$” indicates United States Dollars

190 These statistics are inconsistently detailed across numerous sources. I have used the most commonly cited 
For 20 years after independence, successive governments sought to stimulate sugar industry production. In 1976, cane production was 272,000 tonnes, before peaking in 1980 at 475,000 tonnes. From 1981 to 1990, cane production averaged 416,800 tonnes, which increased between 1990 and 1995, to 439,000, before falling again between 1995 and 2000 to 357,750 tonnes. Sugar production further decreased again between 2000 and 2006 to 310,000 tonnes and is now projected to fall by up to $40 \%$ in coming years. ${ }^{191}$

The Fijian sugar industry's Master Award governs the sharing of proceeds between sugar farmers and the Fijian Sugar Corporation (FSC). Under the 1984 Master Award, the payment that sugar farmers receive is dependent on cane production of the industry as a whole. ${ }^{192}$ If output is less than 325,000 tonnes, growers receive $70 \%$ and the FSC receives $30 \%$ of revenue from sales. If production is between 325,000 and 350,000 tonnes, growers receive $72.5 \%$ and the FSC receives $27.5 \%$. While, if production is above 350,000 tonnes, growers receive $75 \%$ and the FSC receives $25 \% .{ }^{193}$

Britain's departure from Fiji, in 1970 brought with it the disengagement of the Fijian domestic economy from the British economy. Although this also brought a transition of Fijian exports from guaranteed British markets to world-markets, Britain extended its 1950 Colonial Sugar Agreement (CSA), maintaining preferential market access and subsidies for Fijian sugar. Under the CSA, Britain provided Commonwealth countries, including Fiji, preferential access to its markets for set quotas of sugar at a negotiated price. Between the its inception and the signing of the Sugar Protocol the CSA's negotiated price exceeded the world market price by an average of $165 \%{ }^{194}$

The European Economic Community’s (EEC) 1975 Sugar Protocol, under the Lomé

statistics across the following sources. The figures listed are for between 1997-2001. Fiji Sugar Corporation, "The Fiji Sugar Industry," p. 318, P. Lal, H. Lim-Applegate, and M. Reddy, "Alta or Nlta: What's in a Name? Land Tenure Dilemma and the Fiji Sugar Industry," in Working Paper No. 46, October 2001 (Land-Tenure Center, University of Wisconsin-Madison, 2001), p. 1.; Narayan and Prasad, "Economic Importance of the Sugar Industry in Fiji: Stimulating the Impact of a 30\% Decline in Sugar Production," p. 2.; Mahendra Reddy, "Production Analysis of Fiji's Sugar Industry. Unpublished Ph.D Dissertation" (University of Hawaii, 1998), p. 130.

191 Narayan and Prasad, "Economic Importance of the Sugar Industry in Fiji: Stimulating the Impact of a $30 \%$ Decline in Sugar Production," p. 4.

192 The Master Award refers to sugar farmers as "growers". Sugar Industry Tribunal, "Sugar Industry Tribunal Master Award," (Suva: Sugar Industry Tribunal, 1997).

193 Ibid., Part 20, Section 20.2, p. 61.

${ }^{194}$ Malakai Tadulala, Sugar Protocol Agreement 1998,

www.parliament.govt.fj/publications/viewResearch.aspx?research=21 (accessed 21/4/2008). 
Agreement, formalised the EEC's trade relations with the African, Caribbean and Pacific (ACP) sugar producers. The EU centralised administration of trade preferences for its member states with their former colonies in a uniform manner. The Sugar Protocol was extended under the EU's 2000 Cotonou agreement, which superseded the Lomé Agreement. The Sugar Protocol has provided Fiji a set quota for sugar imports to EU markets, which provides it total exemption from import duties on sugar, and a negotiated price far above the world market price. ${ }^{195}$ In addition to the Sugar Protocol quota, since 1995 Fiji has received further quota access to European markets through the EU's Special Preferential Sugar (SPS) scheme. The SPS was developed to formalise sugar trade arrangements with Portugal's former colonies. The SPS scheme encompassed the mechanisms from the Sugar Protocol, through which the EU had previously used to satisfy its sugar refiners' demands when they were excess to what the Protocol's quotas provided. The SPS scheme's allocation is divided amongst the five ACP non-Protocol signatory countries. The remaining allocation is shared amongst the Protocol signatories on a pro rata basis.

Under the Sugar Protocol, the EU has imported nearly 1.3 million tonnes of sugar annually from 16 ACP countries, of which Fiji has received a guaranteed quota of $12.75 \%$, or 165,348 tonnes per year. ${ }^{196}$ In addition to this quota, under the SPS, Fiji has received an extra allocation of approximately $9.3 \%$ or an additional 30,000 tonnes of sugar to sell on European markets. ${ }^{197}$ The Protocol and SPS have allowed Fiji to export an average of about 200,000 tonnes of sugar annually to the EU. ${ }^{198}$ Despite these fixed allocations, yearto-year, Fiji's total sugar export production has varied greatly, sometimes exceeding the quotas such as in 1995, when it exported 246,532 tonnes to the EU. In other years sugar exports have fallen short of the Protocol's quota, as occurred in 2003 when it exported

195 The Sugar Protocol will cease on the 1 October 2009. It will be replaced by individual agreements under Economic Partnership Agreements. This decision was made by the Council of the European Union 28 September 2007. See discussion in chapter six. The Council of the European Union, "Council Decision to Denounce the Acp Sugar Protocol," (Brussels: The Council of the European Union, 2007). 13345/07 (Presse 213)

${ }^{196}$ European Commission, "A Description of the Common Market Organisation of the Market in Sugar Acp Protocol/Agreement with India - Annex Iii," (Brussels: European Commission, 2004), p. 27.

${ }^{197}$ On occasion this figure has been as high as 60,000 tonnes of sugar. This variance is due to the year-to-year demands of the EU's refiners'. Jane Kelsey, "A People's Guide to the Pacific Economic Partnership Agreement. Negotiations between the Pacific Islands and the European Union Pursuant to the Cotonou Agreement 2000," in World Council of Churches (Suva2005), p. 58.

198 European Commission, "The European Sugar Sector: A Long-Term Competitive Future," (Brussels: European Commission, 2006), September 2006, Section 4, pp. 2-3.; Kelsey, "A People's Guide to the Pacific Economic Partnership Agreement. Negotiations between the Pacific Islands and the European Union Pursuant to the Cotonou Agreement 2000," p. 58. 
only 159,254 tonnes. ${ }^{199}$

The Sugar Protocol's guaranteed price has been directly tied to the EU's Common Agricultural Policy (CAP) payment for sugar. ${ }^{200}$ This guaranteed price has amounted to between two-and-a-half and three times the world market rate for sugar per tonne. ${ }^{201}$ Tate and Lyle, a London based sugar refinery, has purchased virtually all the Sugar Protocol ACP signatories have produced. The SPS scheme guarantees prices through the same process as the Protocol, but at $85 \%$ of the Protocol's guaranteed price. ${ }^{202}$

Once the allocation of annual quotas of sugar exports to the EU are set, the Fijian Marketing Association sells the balance of yields to second-tier premium markets. This has predominantly been to Japan and the United States, who have also paid prices significantly higher than world market price to ensure the security of supply year-to-year for their refiners. The United States has also purchased between 10,000 and 20,000 tonnes of sugar annually, ${ }^{203}$ at a rate between two to three times the world market rates. ${ }^{204}$ Fiji's remaining sugar has then been sold on the open market for world market prices.

\section{The comparative efficiency of the Fijian sugar industry}

The small size of sugar farms and the sugar industry's dependence on native land for leases (due to the scarcity of freehold land), combined with high lease rents and the coercive monopsony of sugar industry's miller has resulted in severe inefficiencies within Fiji's sugar industry. Specifically, the structure of Fiji's land-tenure system makes its sugar industry unique in contrast with other Sugar Protocol signatories'. The structure of the sugar industry provides Fiji with a highly inefficient process of production, making Fiji a 'low productivity producer' of sugar. ${ }^{205}$ In contrast with 'high productivity producers', such as

${ }^{199}$ European Commission, "Eu-Acp Trade Main Products Imported 2003, Acp Statistical Analysis," (European Commission, 2003).

$200 \ldots$, "A Description of the Common Market Organisation of the Market in Sugar - Acp Protocol/Agreement with India - Annex Iii," p. 16.

${ }^{201}$ Lal, Lim-Applegate, and Reddy, "Alta or Nlta: What's in a Name? Land Tenure Dilemma and the Fiji Sugar Industry," p. 2.

202 Kelsey, "A People's Guide to the Pacific Economic Partnership Agreement. Negotiations between the Pacific Islands and the European Union Pursuant to the Cotonou Agreement 2000," p. 58.

203 Donald Mitchell, "Sugar Policies: Opportunity for Change," in World Bank Policy Research Working Paper 3222 (Development Prospect Group, The World Bank, 2004), p. 39.

204 Wali M. Osman, "Fiji: Economic Report, September 1998 " (Honolulu: Bank of Hawaii, 1998), p. 20.

${ }^{205}$ In his working paper Mitchell uses the labels 'low cost' to describe producers with a higher tonnage output per employee and 'high cost' to describe producers with a lower tonnage output per employee. These labels are misleading, however, as there are no financial factor in either measure used to attain the ratio and within the measures presented by Mitchell nothing is 'costed' at all. Therefore I have used the more accurate labels of 'high productivity' in the place of 'low cost' and 'low productivity' instead of 'high 
Guyana, which produces 16.3 tonnes of sugar per industry employee, Fiji produces only 8.3 tonnes of sugar per industry employee (See Appendix 1). ${ }^{206}$ This low productivity magnifies the Fijian sugar industry's dependence on the EU's subsidy payment.

Yet, it is not the presence of subsidy alone that determines productivity, but what countries do with it. The cases of Fiji, Kenya and Mauritius suggest (See Appendix 1), as is often claimed, that the presence of the Sugar Protocol's subsidy has disincentivised competitive production leading to inefficient production and low productivity. ${ }^{207}$ The case of Guyana, however, suggests this correlation is not as clear as is claimed. Guyana has been a recipient of Sugar Protocol subsidy payments whilst still producing sugar at a rate comparable with the most productive sugar producing countries, and producing similar amounts of sugar to Fiji annually. Guyana embarked upon structural reform of its economy in 1989, which included the devaluation of its currency. ${ }^{208}$ Devaluation provided Guyana's sugar industry with growth in foreign exchange earnings, which provided the Guyana Sugar Corporation greater capacity to access and utilise investment capital to develop its infrastructure. ${ }^{209}$ The case of Guyana demonstrates that, even with high earnings and a lack of competition, the right domestic institutional structures can make it possible to produce sugar at internationally competitive rates (per employee).

\section{Causes of inefficiencies in the Fijian sugar industry}

The structure of Fiji's land-tenure system, which creates a dependence of sugar farmers on native land lease agreements, and the position of the NLTB as monopoly provider of these highly inflated lease rents, makes sugar production in Fiji unique. In addition, the FSC's status as monopsony buyer of sugar cane has inhibited comparative efficient production with comparable Sugar Protocol subsidy recipients such as Guyana.

The milling of sugar in Fiji has been a monopsony since it began. The Colonial Sugar Refining Company (CSR), an Australian-owned company, operated milling in Fiji without

cost'.

206 Donald Mitchell, "Sugar Policies: Opportunities for Change, Development Prospects Group," in Global Agricultural Trade and Developing Countries, ed. M. Ataman Aksoy and John C. Beghin (Washington DC: The International Bank for Reconstruction and Development / The World Bank, 2005), p. 145

${ }^{207}$ J. C. Bureau, H. Guyomard, and V. Requillart, "Inefficiencies in the European Sugar Regime," Journal of Policy Modeling 23, no. 6 (2001).

208 Adrian P. Hewitt, "Guyana, Sugar and Eba: Case-Study of a Country Which Is Not Quite Least Developed," in The Regulatory Framework of Globalisation (Barcelona, Spain: Overseas Development Institute, London, 2001), pp. 15-16.

${ }^{209}$ Ibid., p. 17. 
competition from 1882 to 1973 . CSR's dominance, as the sole miller in the industry provided it with the ability to control cane payout to sugar farmers. In 1969, after dispute between the miller and growers, the Denning Report investigation and recommendations, led to reform of the payout to sugar farmers. ${ }^{210}$ Following this reform, having initially viciously disputing the Denning Report's recommendations, ${ }^{211}$ the CSA sold its operation in 1973 with the Fijian government purchasing a considerable share. The government now holds approximately $68 \%$ of the FSC. Since its takeover, little reinvestment has gone back into milling infrastructure. Even the FSC has described its infrastructure as "mills [that] are old, overturned, not automated, and expensive to operate and maintain. Further, they are not equipped to make the quality of sugar the market is increasingly demanding." 212 Across the industry, productivity stagnated over the twenty-year period 1978-1998. ${ }^{213}$ Although the FSC bears much responsibility for the flagging investment within the industry, the highest inefficiencies remain are at the level of sugar production on farms. ${ }^{214}$

The structure of Fiji's land system, with the alienation of $87 \%$ of land from the market, creates vast inefficiencies within the sugar industry. Economic analysis has demonstrated that tenant-operated farms are substantially less efficient than owner-operated farms. ${ }^{215}$ The lack of security of agricultural leases, heightened since 1997 with expiry of the ALTA lease agreements, ${ }^{216}$ has inhibited potential long-term investments on sugar farms operated on leased land. Whereas farmers operating on freehold land have been able to raise capital loans against their freehold land, and are then able to reinvest in their production of sugar. Farmers on leased land have been unable to do this. ${ }^{217}$ The evidence that lease land impinges on efficiency improvements, partnered with the presence of high lease rents, as explained in the preceding section, has been sustained in part by the EU's subsidy payment.

${ }^{210}$ Lord Denning, "The Award of the Rt. Hon. Lord Denning in the Fiji Sugar Cane Contract Dispute 1969," (Suva: The Government of Fiji, 1970).

211 The CSR claimed Denning lacked understanding of accounting principals and the practical working of the sugar industry. It asserted the implementation the the Denning Report would impose high risks on the miller, with little or no prospect of worthwhile profits. The Colonial Sugar Refining Company Limited, "Lord Denning's Award Concerning the Fiji Sugar Cane Contract: Observations on Its Consequences and Mistakes," (Sydney: The Colonial Sugar Refining Company Limited, 1970).

${ }^{212}$ Fiji Sugar Corporation, "The Fiji Sugar Industry," p. 316.

213 Reddy, "Production Analysis of Fiji's Sugar Industry. Unpublished Ph.D Dissertation", p. 118.

214 Ibid., p. 118-19.

215 Mahendra Reddy demonstrated this in his Ph.D dissertation and subsequent journal article. He also notes all prior attempts to demonstrate this failed due to flawed methodologies. Ibid., pp. 118-19.

216 As is explained further in Chapter Five.

${ }^{217}$ Mahendra Reddy, "Implication of Tenancy Status on Productivity and Efficiency: Evidence from Fiji," Sri Lankan Journal of Agricultural Economics 4, no. 1 (2002): p. 31. 
The Sugar Protocol subsidy has not produced inefficiencies within Fijiss sugar industry per se; rather, it has provided a surplus income to the industry, which permits the maintenance of illiberal institutions and inefficient practices. Had Fiji's domestic institutions been liberalised and legal monopolies eliminated, the Fijian sugar industry might have achieved productivity levels comparable with the most efficient producers. This is, however, a counterfactual.

These illiberal institutions have been critical in perpetuating the dominance of a chiefly elite over the Fijian economy and polity. The Sugar Protocol subsidy has buffered Fiji's land-tenure system from conditions on world markets, and thus, maintained the structure of the land-tenure system, its high lease rents, and the NLTB's management of these. The following section demonstrates how these inflated lease rents are filtered down a tiered system, which sustains the chiefs' position over Fijian society.

\section{The distribution of native land rents}

Proprietary unit's native land lease rents are distributed down a formalised mechanism as stipulated in legislation. This stipulated distribution of rents was institutionalised as a means of indirect rule providing political patronage to chiefly elite by colonial authorities. The stipulated distribution's structure is a reflection of the pre-colonial chiefly hierarchy as drawn by Maxwell in 1913.

Lease rents are distributed to the proprietary unit from the NLTB, which collects lease rents from landowners. The NLTB receives poundage for its management of the lease agreements. With both lease rents distributed to proprietary units and poundage received and spent by the NLTB, the chiefly elite has vast control over all lease rents. Within proprietary units, the tiered distribution of rents provides chiefs with sinecures, and the remaining income is managed in an ad hoc manner by the turaga of the proprietary units, see Figure 3. Although turaga of proprietary units are obliged to share the income equally amongst the unit, they are entitled to distribute it as they wish. This gives chiefs discretion over the majority of lease rents, facilitating their dominance over Fijian society. The poundage paid to the NLTB for its management of native land also provides the chiefs with access to vast material resources, adding to their material advantages over Fijian 
society. As is explained in the following section, little about the NLTB's financial operations historically can be ascertained, due to its opaque accounting practices and financial records.

Figure 3: Tiered Distribution of Native Land Lease Rents

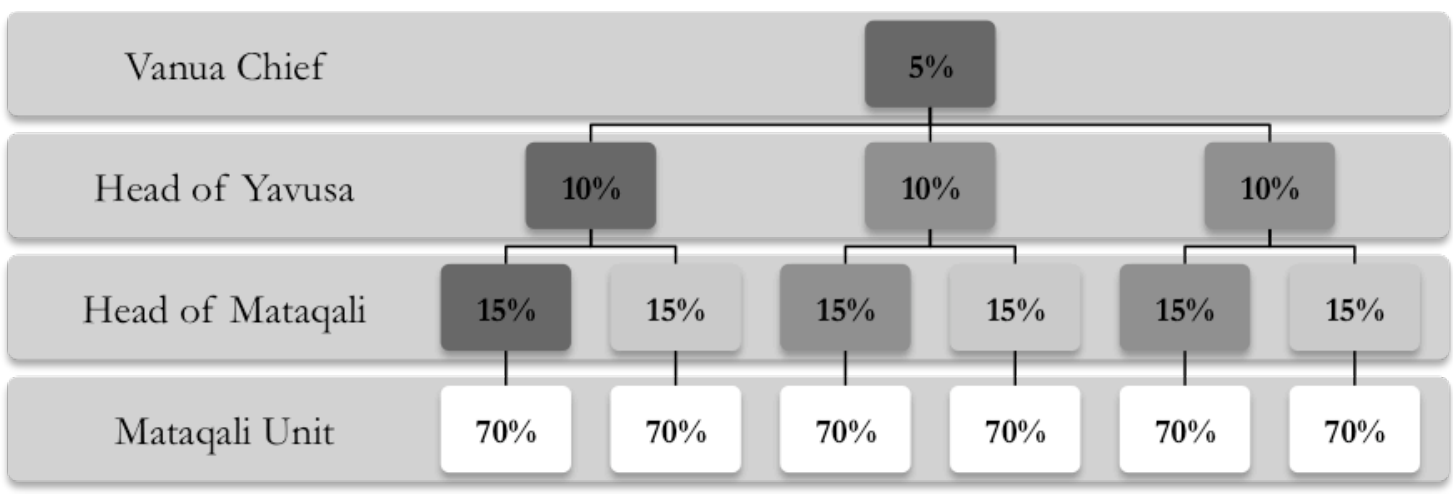

Source: Native Land Trust Act 1970. Section 11 (1)

Pacific-Fijian tribal hierarchy has been reinforced and perpetuated through the tiered distribution of land rental income from native land leases (see Figure 3). The tribalhierarchy was first institutionalised in 1940 under the NLTO, ${ }^{218}$ legislation that stipulates that lease payments are to be paid by lessees down a tiered structure that reflects the hierarchical levels of the chiefly system. The NLTB subtracts its poundage charge for managing the native land and then distributes the rents. ${ }^{219}$ Of the total lease rent remaining, the turaga $i$ tankei, or head of vanua (district) ${ }^{220}$ receives $5 \%$ of the rents paid to their mataqali, and all mataqali within their vanua; ${ }^{221}$ the head of the turaga ni yavusa, or head of yavusa $^{222}$ receives $10 \%$ of the rents paid to their mataqali, and all mataqali within their yavusa, ${ }^{223}$ and the turaga ni mataqali, or head of the mataqali, ${ }^{224}$ receives $15 \%$ of the rents paid to their mataqali. ${ }^{225}$ The remaining $70 \%{ }^{226}$ of the lease rent is distributed to the turaga ni mataqali, or head of the proprietary unit, who is obliged to distribute the sum fairly

218 After independence this was formalised under the 1970 NLTA

219 Native Land Trust Act 1970. Chapter 134, Section 33, provision 11(1)

220 Or Turaga ni Vanua

221 Native Land Trust Act 1970. Section 33, provision 11(1)(d)

222 Or Turaga ni Qali

223 Native Land Trust Act 1970. Chapter 134, Section 33, provisions 11(1) and(c)

224 Ibid. Section 33, provision 11(1)(b)

225 There are varied interpretations of the distribution of lease rents. Commonly it is stated that from the overall lease rent the NLTB gets $15 \%$, the turaga i taukei $5 \%$, the turaga ni yavusa $10 \%$, the turaga ni mataqali $15 \%$ and the then the turaga ni mataqali receives $45 \%$ to distribute amongst the mataqali. In addition, NLTB General Manager, in an article published in 1988 stated the actual distribution levels were in fact: $3.75 \%$ to the turaga i taukei, $7.5 \%$ to the turana ni yavusa, $11.25 \%$ to turaga ni mataqali and $52.5 \%$ to the mataqali (including the $25 \%$ to the NLTB). Due to the inconsistency across the literature I have used the distribution as stipulated in the NLTA.

226 Native Land Trust Act 1970. Section 33, provision 11(1)(a) 
amongst the people within that unit. ${ }^{27}$

The tiered hierarchical distribution of lease rents provides cumulative rents for chiefs, exacerbating disparities between chiefs and commoners. As explained earlier in Figure 1, vanua units encompass multiple yavusa, and yavusa units encompass multiple mataqali. Thus, vanua and yavusa chiefs collect cumulative rents in accordance with their chiefly roles. All heads of vanua are also the head of their yavusa and the head of their mataqali. Therefore, heads of vanua receive $5 \%$ of rents received by mataqali units within their vanua, and as the head of yavusa they collect $10 \%$ of rents received by mataqali. ${ }^{228}$ All heads of yavusa are head of their mataqali. Therefore, heads of yavusa receive $10 \%$ of rents received by all mataqali units within their yavusa, and as head of the mataqali, they receive $15 \%$ of rents received by their mataqali, whereas heads of mataqali collect the $15 \%$ of rents received by their mataqali.

There are no checks on the distribution of rents amongst landowners, allowing the turaga to distribute the rents as they see fit. Since the rules surrounding rent distribution has not been reformed since the 1940 NLTO, the mechanism of resource allocation designed by colonial administration to entrench chiefly hierarchy and assist indirect rule was never adjusted for the transition from independence to liberal democracy. Such distribution of lease rents among proprietary units has encouraged a particular relationship between Pacific-Fijians and their mataqali. To receive a share of rental income, Pacific-Fijians must preserve a close association with their mataqali and its turaga. Where Pacific-Fijians cannot identify their mataqali, they cannot claim lease rents. At the 1956 census, only $66 \%$ of Pacific-Fijians were able to identify the mataqali and yavusa to which they belonged. ${ }^{229}$ The control provided to turaga over rent distribution therefore provides material incentives for Pacific-Fijians to actively observe chiefly hierarchy. It also imposes costs on Pacific-Fijians who live lives, either through choice or circumstance, disconnected from tribal life and their historical lineage. ${ }^{230}$ The institutionalisation of such stark mechanism of rent distribution accentuates material disparities and the social hierarchy within the traditional social unit. These fixed social structures not only permeate the maintenance of tribal hierarchy, but

\footnotetext{
227 Ibid. Section 33, provision 11(3)

${ }^{228}$ I have used mataqali as the example of a land owning proprietary unit because they are the most common land owning unit. However, this rent distribution structure described applies to all landowning units.

${ }^{229}$ Interestingly this question has not featured in subsequent censuses. The absence of this data displays elite's desire to not track the decay of Pacific-Fijians associations with their tribal units. France, The Charter of Land: Custom and Colonization in Fiji p. 174.

230 These are predominantly urban Pacific-Fijians.
} 
also facilitate the chiefly elites manipulation of Pacific-Fijian communal politics and political parties.

The poundage paid to the NLTB also provides Fiji's high chiefs with direct control over large financial resources. Between 1940 and 1998, poundage was fixed at 25\% of the lease rents. ${ }^{231}$ As well as collecting poundage for lease rents, the NLTB also collects poundage on premium payments. After the presentation of the NLTB's Annual Report in 1997, its first in seven years, the NLTB's Board of Trustees agreed to an external review of the NLTB's practices. The Coopers \& Lybrand's report from its review, presented in March 1998, stated: "[The NLTB is] not maximising opportunities to increase the level of income flowing to the landowners", it "is not operating in a business like manner" and is "over resourced and inefficient." It also concluded that, "the poundage level of $25 \%$ is excessive" ${ }^{232}$ As a result, poundage was decreased incrementally from $25 \%$ to $15 \%$, at a rate of 5\% per year between 1999 and 2001. ${ }^{233}$ Nevertheless, this decrease resulted in an increase in residual rents distributed to proprietary units through the mechanism stipulated. The NLTB's records reveal it has compensated for the decrease in poundage by raising administration fees and premium costs, leaving little real increase in net residual rent for landowners. ${ }^{234}$

\section{NLTB accountability}

The NLTB holds a legal monopoly on land-leases. ${ }^{235}$ This permits the NLTB to inflate lease rents and it is the Council of Chiefs, which exercises direct control over the NLTB

231 Native Land Trust Act 1970. Section 14(1).

The $25 \%$ figure for poundage was set as an estimate cost of the NLTB's operation. These were the following proportions: $9 \%$ for land agency and land administration; $10 \%$ for office administration, secretarial and conveyancing; and 6\% for accountancy, collection and distribution of rents. Prasad, "Property Rights, Economic Performance and the Environment in Fiji: A Study Focusing on Sugar, Tourism and Forestry Unpublished Ph.D Dissertation", p. 83.

232 Native Land Trust Board, "Native Land Trust Board Annual Report 1998," (Suva: Native Land Trust Board, 1998), p. 9.

233 This decrease was not obliged by legislation. Rather, it was a directive from the Board to management, after the financial mismanagement between 1990-1997. Mara's comment in —_, "Native Land Trust Board Annual Report 1990-1997," (Suva: Native Land Trust Board, 1998), pp. 4-5.

234 __ "Native Land Trust Board Annual Report 1999," (Suva: Native Land Trust Board, 2000), p. 9. 235 Biman Prasad points out that in academic studies of the Pacific, the study of multinational corporations has been given attention but traditional and local institutional monopolies have largely been ignored. He points in particular to the NLTB and its legally entrenched monopoly and monopsony over leases and landowners respectively in Fiji, have received little attention from scholars. Prasad, "Property Rights, Economic Performance and the Environment in Fiji: A Study Focusing on Sugar, Tourism and Forestry Unpublished Ph.D Dissertation", p. 82. 
and, through it, considerable influence within the Fijian economy. Since the role of high chiefs is institutionalised within the tiered distribution of lease rents, chiefs have personal incentives to inflate lease rents. This is further supported by the NLTB's opaque presentation of its financial activities in its annual reports.

Through its collection of poundage from native land lease rents and premiums, the NLTB also commands vast political and economic institutional power in Fiji. This political power has provided the NLTB with relative freedom in prescribing and adhering to loose financial management. The NLTB's financial records, presented in its annual reports, provide an incomplete picture, and what is present lacks reliability.

The NLTB is a dominant actor in Fiji's political economy. Established in 1940, by the colonial administration and Ratu Sir Lala Sukuna, the NLTB manages all native land leases. In doing this, it approves all new lease agreements and the renewal of expired lease agreements. The NLTB's Board of Trustees possesses vast power in Fiji, so much, that it holds the statutory ability to regulate its own operations. This is facilitated by provisions in the NLTA that allow the NLTB to "make its own rules as to its own proceedings under this Act and the carrying out of the powers vested in the [Native Land Trust Board's] Board [of Trustees] by this Act." 236

Pacific-Fijian high chiefs, through the Council of Chiefs, hold considerable influence over the NLTB, and appoint of a majority of its Board of Trustees. The Council of Chiefs itself appoints five of the 12 members of the NLTB's Board of Trustees and the remaining Trustees are the President of Fiji, three Fijian Affairs Board nominees, two nominated by the President, the Minister of Fijian Affairs, who chairs the Board of Trustees, and the Board of Trustees' Secretary. ${ }^{237}$ As the President is appointed on the advice of the Council, it also holds indirect influence over the three presidential nominees to the Board of Trustees. The President holds the power to dismiss any non-Pacific-Fijian appointee to the Board of Trustees. In contrast, the President cannot dismiss PacificFijians from the Board of Trustees. ${ }^{238}$ Overall, these rules provide the Council with positional influence over eight of the 12 Board of Trustees members.

236 Native Land Trust Act 1970. Section 3(5)

${ }^{237}$ Ibid. Section 3(1)

238 Ibid. Section 2(b) 
The NLTB has received substantial income through the poundage it collects from native lease activity, but it provides little information about what it does with these resources. NLTB financial reports list its greatest expense as the salaries for employees of the NLTB and members of its Board of Trustees. Despite the decrease in poundage to 15\% in 2001, the NLTB still collects far more than comparative tertiary service asset managers. ${ }^{239}$ Tertiary service industries also tend to pay the staff no more than $50 \%$ of their income they receive. ${ }^{240}$ In contrast, in 2001 the NLTB paid out $85 \%{ }^{241}$ of the poundage collected out in salaries, in 2002 , it paid out $75 \%{ }^{242}$ As the NLTB is in many ways the corporate embodiment of the chiefly elite, this 'poundage' merely represents a transfer of resources to high chiefs.

The NLTB's financial reports present flawed accounting procedures that insulate it from financial accountability. The NLTB's accounting practices appear to straddle both public and private accounting standards. This can be interpreted as an attempt to shield the NLTB's financial operations from public scrutiny. A more charitable interpretation, however, is that the NLTB's confused legal status has translated into confused financial reporting. Indeed, the NLTB describes itself as "not part of government, rather...a partner of government in the development of Fiji." ${ }^{243}$ Its collection and distribution of lease rents is within a private capacity. In its capacity as the manager of native land leases, however, the NLTB acts in a public capacity. Private and publicly accountable institutions are required to adhere to differing accounting standards. The ambiguity surrounding the NLTB's legal state has created uncertainty around the accounting standard to which it must adhere.

The NLTB's financial reports are riddled with inconsistencies and practices that conceal more information than they reveal. The NLTB's Annual Reports for the period 1976-2004 claim that the NLTB's “... [accounting] policies do not require the application of all Fiji

239 Parsad, Biman C.,__ , "Property Rights, Economic Performance and the Environment in Fiji: A Study Focusing on Sugar, Tourism and Forestry - Unpublished Ph.D Dissertation".

It is cited that private rental arrangements in Queensland only charge approximately $7.5 \%$ of the rents collected.

240 Olivia Majesky, "Metric of the Month: Salaries as a Percentage of Operating Expense," Society for Human Resource Management Research Quarterly 8-9 (2008).

241 Native Land Trust Board, "Native Land Trust Board Annual Report 2001," (Suva: Native Land Trust Board, 2002), p. 25.

242 _ , "Native Land Trust Board Annual Report 2002," (Suva: Native Land Trust Board, 2002), p. 27.

243 _ 
Accounting Standards." ${ }^{244}$ The NLTB's auditors also acknowledge the NLTB's substitution of accounting standards, "In our (the auditor's) opinion, the financial statements have been prepared in accordance with the accounting policies described in Note 1 to the financial statements..." Note 1 states that the report has been prepared on the basis of "historical costs and...do not take into account current valuation." ${ }^{245}$ Citing the incompatibility of the Fiji Accounting Standards (including both modified historical cost and market valuations) with the function of the NLTB, as a manager of an untradeable asset, the NLTB has developed its own accounting standards. The NLTB states that "the accounting policies adopted are consistent with those of the previous year unless otherwise stated, but do not conform with all standards promulgated by the Fiji Institute of Accountants." 246 The

244 Across this time period the wording has differed slightly, but its substance has not. I have used the most recent wordings. __ , "Vanua: Native Land Trust Board Annual Report 1976," (Suva: Native Land Trust Board, 1977), p. 23.; —_ " "Vanua: Native Land Trust Board Annual Report 1977," (Suva: Native Land Trust Board, 1978), p. 13.; ___ "Vanua: Native Land Trust Board Annual Report 1978," (Suva: Native Land Trust Board, 1979), p. 10.; —_ "Vanua: Native Land Trust Board Annual Report 1979," (Suva: Native Land Trust Board, 1980), p. 8.; —_, "Vanua: Native Land Trust Board Annual Report 1980," (Suva: Native Land Trust Board, 1981), p. 8.; —_ _ "Vanua: Native Land Trust Board Annual Report 1981," (Suva: Native Land Trust Board, 1982), pp. 8, 17.; —_, "Vanua: Native Land Trust Board Annual Report 1982," (Suva: Native Land Trust Board, 1983), pp. 8, 17.; —_, "Vanua: Native Land Trust Board Annual Report 1983," (Suva: Native Land Trust Board, 1984), pp. 8, 15.; "Vanua: Native Land Trust Board Annual Report 1984," (Suva: Native Land Trust Board, 1985), pp. 8, 15.; _ - "Vanua: Native Land Trust Board Annual Report 1985," (Suva: Native Land Trust Board, 1987), pp. 8, 15.; _ "Vanua: Native Land Trust Board Annual Report 1986," (Suva: Native Land Trust Board, 1988), pp. 12, 24.; ___ "Vanua: Native Land Trust Board Annual Report 1987," (Suva: Native Land Trust Board, 1989), pp. 16, 29.; __ , "Vanua: Native Land Trust Board Annual Report 1988," (Suva: Native Land Trust Board, 1991), pp. 8, 21.;_—_ "Vanua: Native Land Trust Board Annual Report 1989," (Suva: Native Land Trust Board, 1991), pp. 9, 22.; —_, "Native Land Trust Board Annual Report 1990-1997," pp. 21, 39, 47, 63, 71, 88, 96, 112, 20, 36, 44, 60, 68, 83, 91, 205.; _ , "Native Land Trust Board Annual Report 1998," pp. 27, 41.; ___, "Native Land Trust Board Annual Report 1999," pp. 19, 35.; _ _ "Native Land Trust Board Annual Report 2000," (Suva: Native Land Trust Board, 2001), pp. 23, 39.; ___ "Native Land Trust Board Annual Report 2001," pp. 14, 29.; —_ , "Native Land Trust Board Annual Report 2002," pp. 26, 45.; __ , "Native Land Trust Board Annual Report 2003," (Suva: Native Land Trust Board, 2003), pp. 23, 40.; —_, "Native Land Trust Board Annual Report 2004," (Suva: Native Land Trust Board, 2005), pp. 20, 42.

245 Native Land Trust Board, "Vanua: Native Land Trust Board Annual Report 1976," p. 26.; ___, "Vanua: Native Land Trust Board Annual Report 1977," p. 16.;___, "Vanua: Native Land Trust Board Annual Report 1978," p. 14.; _ _ , "Vanua: Native Land Trust Board Annual Report 1979," p. 13.; ___, "Vanua: Native Land Trust Board Annual Report 1980," p. 13.;___, "Vanua: Native Land Trust Board Annual Report 1981," p. 13.; __ , "Vanua: Native Land Trust Board Annual Report 1982," p. 13.; , "Vanua: Native Land Trust Board Annual Report 1983," p. 13.; ___, "Vanua: Native Land Trust Board Annual Report 1984," p. 13.; —_ "Vanua: Native Land Trust Board Annual Report 1985," p. 13.; , "Vanua: Native Land Trust Board Annual Report 1986," p. 17.;___, "Vanua: Native Land Trust Board Annual Report 1987," p. 20.; —_ "Vanua: Native Land Trust Board Annual Report 1988," p. 12.; _ , "Vanua: Native Land Trust Board Annual Report 1989," p. 13.; __, "Native Land Trust Board Annual Report 1990-1997," pp. 26, 51, 75, 100, 24, 48, 72, 95.;_—_ "Native Land Trust Board Annual Report 1998," p. 31.;___ "Native Land Trust Board Annual Report 1999," p. 23.;___, "Native Land Trust Board Annual Report 2000," p. 27.; —_ , "Native Land Trust Board Annual Report 2001," p. 18.; ——, "Native Land Trust Board Annual Report 2002," p. 31.;___, "Native Land Trust Board Annual Report 2003," p. 28.; — "Native Land Trust Board Annual Report 2004," p. 25.

246 Native Land Trust Board, "Vanua: Native Land Trust Board Annual Report 1976," p. 26.; __ , "Vanua: Native Land Trust Board Annual Report 1977," p. 16.; —_, "Vanua: Native Land Trust Board Annual Report 1978," p. 14.; _ _ , "Vanua: Native Land Trust Board Annual Report 1979," p. 13.; _— "Vanua: Native Land Trust Board Annual Report 1980," p. 13.;___, "Vanua: Native Land Trust Board 
NLTB's claim regarding the maintenance of its 'traditional' 247 accounting practices seems to serve its political objectives over its financial needs.

The inconsistencies in the NLTB's use of accounting standards go some way toward exposing the practices they exist to conceal. The NLTB undermines it own claim that modified historical cost and market valuations are inappropriate for its financial operations by using both mechanisms in other sections of its financial reporting. For example, it obeys historical cost techniques by using depreciation in the presentation of its accounts and it recognises market valuations through its use of contingent liabilities in its financial reports. In addition, in its presentation of its investments, on records them according to their historical cost valuation. ${ }^{248}$

Furthermore, the NLTB has a history of the delayed filing of annual reports well after the year of focus. It did not release annual reports between 1990 and 1996. Instead, in 1997 it released a seven-year retrospective report. The 1990 audit report was signed off in September 1996, whilst the 1991-1996 audit reports were all signed off in late $1997 .{ }^{249}$ In

Annual Report 1981," p. 13.; __ _ "Vanua: Native Land Trust Board Annual Report 1982," p. 13.; — —, "Vanua: Native Land Trust Board Annual Report 1983," p. 13.; ——, "Vanua: Native Land Trust Board Annual Report 1984," p. 13.; _ _ _ "Vanua: Native Land Trust Board Annual Report 1985," p. 13.; _ _ "Vanua: Native Land Trust Board Annual Report 1986," p. 17.;___, "Vanua: Native Land Trust Board Annual Report 1987," p. 20.; — , "Vanua: Native Land Trust Board Annual Report 1988," p. 12.; —_ "Vanua: Native Land Trust Board Annual Report 1989," p. 13.; __, "Native

Land Trust Board Annual Report 1990-1997," pp. 26, 51, 75, 100, 24, 48, 72, 95.;_—_ "Native Land Trust Board Annual Report 1998," p. 31.;_—_ "Native Land Trust Board Annual Report 1999," p. 23.; —_ "Native Land Trust Board Annual Report 2000," p. 27.; —_, "Native Land Trust Board Annual Report 2001," p. 18.; ___ , "Native Land Trust Board Annual Report 2002," p. 31.; —_,

"Native Land Trust Board Annual Report 2003," p. 28.; __ , "Native Land Trust Board Annual Report 2004," p. 25.

247 Native Land Trust Board, "Vanua: Native Land Trust Board Annual Report 1976," p. 26.; ___, "Vanua:

Native Land Trust Board Annual Report 1977," p. 16.;___ , "Vanua: Native Land Trust Board Annual

Report 1978," p. 14.; _ _ "Vanua: Native Land Trust Board Annual Report 1979," p. 13.;

"Vanua: Native Land Trust Board Annual Report 1980," p. 13.; —_, "Vanua: Native Land Trust Board Annual Report 1981," p. 13.; —_ , "Vanua: Native Land Trust Board Annual Report 1982," p. 13.; —

__, "Vanua: Native Land Trust Board Annual Report 1983," p. 13.; ___, "Vanua: Native Land Trust Board Annual Report 1984," p. 13.; __ _ "Vanua: Native Land Trust Board Annual Report 1985," p. 13.; _ _ "Vanua: Native Land Trust Board Annual Report 1986," p. 17.;___, "Vanua: Native Land Trust Board Annual Report 1987," p. 20.; __ , "Vanua: Native Land Trust Board Annual Report 1988," p. 12.; — , "Vanua: Native Land Trust Board Annual Report 1989," p. 13.; —_, "Native Land Trust Board Annual Report 1990-1997," pp. 26, 51, 75, 100, 24, 48, 72, 95.;_—_, "Native Land Trust Board Annual Report 1998," p. 31.;___ "Native Land Trust Board Annual Report 1999," p. 23.; __ , "Native Land Trust Board Annual Report 2000," p. 27.; ___, "Native Land Trust Board Annual Report 2001," p. 18.; —_ , "Native Land Trust Board Annual Report 2002," p. 31.; ——,

"Native Land Trust Board Annual Report 2003," p. 28.; __ , "Native Land Trust Board Annual

Report 2004," p. 25.

248 This is my assertion after having read the conclusion of Ronita Devi Singh and Mahendra Reddy, "Corporate Governance in Fiji's Native Land Trust Board," Pacific Economic Bulletin 22, no. 2 (2007): p. 41. In their analysis of the NLTB's reports.

${ }^{249}$ Native Land Trust Board, "Native Land Trust Board Annual Report 1990-1997," pp. 21, 39, 47, 63, 71, 88, 
addition, between 1985 and 1989 audit reports were signed off over 18 months after the year of the report. ${ }^{250}$

The NLTB is granted the right to determine 'market' values for all lease rents. The exclusion of native land valuations from the NLTB's financial reports, however, limits public knowledge of the value of native land lease rents. This makes it difficult to provide consistent valuations of native land. Although the Committee of Valuers' reports provide the valuations of agricultural lease agreements within the public domain, its valuations are highly inflated as it adopts those of recently sold freehold land (see lease valuation section above). This non-disclosure of native land valuations, means new tenants of nonagricultural leases have no knowledge of what is a fair, or even what the market rate for their lease rents might be. This provides the NLTB vast control in determining lease rents.

Essentially, the NLTB's simple role of administrating native land lease rents should provide it with a relatively minor role in Fijian economy, in which would exist merely as an administrator of lease rents at prices determined by NLTB land valuers. If its operations were this simple, its accounting practices would be expected to also display simplicity. The complex financial operations, however, as displayed by the misleading accounts, suggest the extent to which the administration of native land has been politicised. The presence of the President, Minister of Fijian Affairs and the dominance of the Council of Chiefs over the NLTB's Board of Trustees, speaks to the overtly political role the NLTB plays within Fiji's economy.

The NLTB's financial history displays little financial transparency. The annual presentation of audited financial reports, provide some legitimation to the NLTB as an institution. Nonetheless, its selective application of accounting standards have allowed it to construct its own reality, while communicating, albeit opaquely, that it operates as a sound financial institution, serving a noble purpose. ${ }^{251}$ The NLTB has erected fences around its operations, which are deemed too political for public disclosure, thus excusing itself from presenting

$96,112,20,36,44,60,68,83,91,205$;

$250 \ldots$ _ "Vanua: Native Land Trust Board Annual Report 1985," pp. 8, 15.; __, "Vanua: Native Land Trust Board Annual Report 1986," pp. 12, 24.; —_ "Vanua: Native Land Trust Board Annual Report 1987," pp. 16, 29.; — _ "Vanua: Native Land Trust Board Annual Report 1988," pp. 8, 21.; — "Vanua: Native Land Trust Board Annual Report 1989," pp. 9, 22.

251 Gareth Morgan, "Accounting as Reality Construction: Towards a New Epistemology for Accounting Practice," Accounting Organizations and Society 13, no. 5 (1988).; Ruth D. Hines, "Financial Accounting: In Communicating Reality, We Construct Reality," Accounting Organizations and Society 13, no. 3 (1988). 
native land values and only selectively detailing the operations that present the NLTB's operations in positive light. This loose and inconsistent management of the NLTB's finances, as overseen by its Board of 'Trustees, has centralised the chiefs' control over material resources within the Fijian economy.

\section{Conclusion}

In light of the chiefs' position in the Fijian economy and the constitutional provisions provided to the Council of Chiefs, it is difficult to call Fiji a democracy. The socioeconomic advantages of the chiefly elite, provided by the land-tenure system, are entrenched within the constitution and excluded from the potential elected legislature's and executive's to reform them. Fiji's constitutional structures are not democratic and Fiji was never a democracy.

The veto held by the Councils of Chiefs' senatorial nominees over the land-tenure system is the linchpin of chiefly control over Fijian society and politics. Through the design of the land-tenure system and the high earnings derived from the sugar industry, the chiefly elite is able to control native land, the terms of lease rents and the distribution of rental incomes. These advantages have all served to perpetuate the chiefs' dominance over Fijian society.

The case of Fiji is peculiar. In most cases market forces render illiberal, monopolistic and monopsonistic institutions, such as those in Fiji unsustainable. Market competition would have disciplined NLTB's attempts to use its legal monopoly to inflate lease rents, however, excess earnings provided by the Fijian sugar industry's receipt of EU subsidy payments has in part sustained this situation. These heavily inflated lease rents have been filtered down a tiered mechanism to landowners, directly reproducing Pacific-Fijian chiefs' material advantages over common Pacific-Fijians. Furthermore, the design of Fiji's land tenuresystem has permitted the chiefly hierarchy to exist as an authority parallel to and has repeatedly undermined elected government. 


\section{Chapter Four: Independence and the Resurgence of Authoritarianism $1970-1990$}

Since independence, Fiji has had a troubled experience with electoral governance. The chiefly elite has usurped government when electoral processes have produced political outcomes at odds with their interests. Each time electoral institutions have produced a change of government chiefly control has moved to displace these elected governments. These overthrows of government reflect the depth at which chiefly hierarchy has been entrenched in formal institutions of government, the economic and political powers of the elite outside of the electoral process, and the chiefs' ability to reassert their dominance of government. Moreover, they display how, despite the presence of 'modern' liberal institutions, an authoritarian chiefly elite has maintained its control of government even when electoral institutions threatened to remove it from power.

The dominance of the chiefly elite underlies the façade of Fijian democracy. Fiji's three constitutions have each prescribed a limited role for the chiefly elite, while masking the true extent of its dominance. Entrenchment of the chiefly elite in Fiji's political economy has provided the chiefs' with the means to dominate government within constitutional bounds and, when necessary, through armed force. Control of an infrastructure of illiberal institutions provides the elite with both the financial means and socio-political legitimacy to crush electoral institutions when electoral results do not coincide with chiefly interests.

This chapter examines the chiefly elite's actions to undermine electoral outcomes and ensure the continuation of its control of government. First, it explains the attempts of Ratu Sir Kamisese Kapaiwai Tuimacilai Mara, Prime Minister and leader of the Alliance Party, to forge a cross-ethnic coalition and the electoral consequences of this. Mara's failed attempt to forge a cross-ethnic coalition of voters exposed the static nature of political cleavages and the risks of reforming the fundamental features of the land-tenure system. Second, it addresses the rise of the Fiji Labour Party, its electoral victory in 1987 and the subsequent coup. This coup deposed the Labour-National Federation government, and was the first time the parallel set of authoritarian institutions, controlled by the Pacific-Fijian chiefly elite, was exposed. 


\section{The first Fijian elections 1970-1977}

The general election of 1977 was the first threat to the political dominance of the PacificFijian chiefly elite over Fijian society. The Alliance Party, led by Mara, ${ }^{252}$ had been in power since the pre-independence election of 1968. It guided Fiji through independence and solidified its electoral appeal with victory in the 1972 general election. Following the election, the new Prime Minister sought to consolidate his electoral base. In order to solidify his, and his chiefly peers, control over Fiji's political institutions, he sought to attract votes from the Indo-Fijian population. To do this, Mara attempted to form a new political coalition bridging Fiji's ethnic communities under his leadership and multicultural governance. $^{253}$

Mara appealed to Indo-Fijian voters through their interest in the status of the 1966 ALTO, ${ }^{254}$ which governed agricultural land leases. ${ }^{255}$ Mara, however, overestimated his personal influence in Pacific-Fijian communities, and efforts to construct a coalition with Indo-Fijian interests around ALTO alienated a number of Mara's core supporters. At the 1977 general election, conservative Pacific-Fijian communities abandoned the Alliance Party in reaction to Mara's courting of Indo-Fijian support by passing the 1976 ALTA. However, Mara narrowly escaped the full ramifications of this political misjudgement. Although the National Federation Party ${ }^{256}$ won a plurality of seats at the 1977 election, the

${ }^{252}$ Mara assumed the leadership of the Alliance Party through his status as a high chief and his close associations with a tight elite of European, part European and Indo-Fijian business interests. Mara's chiefly authority arose from his chiefly title, as Tui Nayau. It also came from his wife, Adi Mara's chiefly status, she was from the confederacy of Burebasaga and her title Roko Tui Drekti is the highest chiefly title in the islands. Roderic Alley, "The Emergence of Party Politics in Fiji," in Politics in Fiji: Studies in Contemporary History, ed. Brij V. Lal (North Sydney, New South Wales: Allen \& Unwin, 1986), pp. 34-40.

${ }^{253}$ Mara commonly described policies within his multicultural governance as the "Pacific way". He even used it in the title of his autobiography: Kaimesese Mara, The Pacific Way: A Memoir (Honolulu: University of Hawaii Press, 1997). This "Pacific way" became an ideology used by a number of political elites across various Pacific Islands where it synthesised various local appeals for the maintenance of "tradition". Here the chiefly elite, and particularly Mara, used a combination of traditionalism, ethno-nationalism and ethnic racism and labeled it multiculturalism within the "Pacific way." Michael C. Howard, "Vanuatu: The Myth of Melanesian Socialism," Labour, Capital and Society 16, no. 2 (1983): p. 180-86.

254 See the discussion of this in Chapter Three.

255 The importance of the review of the Agricultural Landlord and Tenant Ordinance in Mara's electoral strategy has been underemphasised by the literature. With the benefit of historical insight and understanding of the political importance of the land tenure system, however, the importance of the legislating of Agricultural Landlord and Tenant Act in Mara's strategy of constructing a cross-ethnic coalition is unmistakable.

256 The National Federation Party grew out of the Federation of Cane Growers, which had been set up in 1960 by Indo-Fijian sugar farmers to voice grievances against the Colonial Sugar Refining Company. The National Federation Party had its first national convention in 1965, where it solidified its constituency amongst the Indo-Fijian community. Initially led by A. D. Patel, who was its first Party president and then leader in the Legislative Council, after his death in late 1969, Siddiq Koya took over as Party leader. Alley, 
distribution of electoral seats left it unable to form a workable coalition and the Governor General called a second election. While constitutional, the consequences of the Governor General's actions raised questions about his impartiality.

This section is in two parts. First, it explains Mara's attempt to court political support from the Indo-Fijian community with the passing of the ALTA. The ALTA formalised lease conditions that favoured leaseholders, mainly Indo-Fijians, against the material interests of the Alliance Party's core constituency. Second, it addresses the general election of 1977 and the challenge it presented to the Alliance Party and its dominance over Fijian politics. The Alliance Party's key strategic reform of its second term translated to electoral overreach. Luckily for the Alliance Party, it was reinstated as government by the Governor General's solution to the constitutional crisis.

\section{ALTA: a political act}

Ahead of the 1977 general election, Mara's government legislated a reform of agricultural land rents to attract Indo-Fijian political support. After independence, all colonial ordinances, including the 1966 ALTO, required a legal review by the government. The Government needed to reform agricultural leases, either by preserving the provisions of ALTO in a post-independence legal framework, favouring lease holders, or by drawing agricultural leases under the terms of the 1970 NLTA, which would extend the chiefly elite's control over native land. Considering Mara's electoral position as the incumbent Prime Minister, it seemed an unusual choice to legislate against the interests of the Alliance Party's core constituency by formalising the ALTO's provisions. ${ }^{257}$

After two general elections, it was clear to Mara that the Alliance Party's long-term dominance of the electoral system would be possible if it could capture votes outside the Pacific-Fijian community. As Indo-Fijians had received little real political representation from either colonial or elected governments, Mara saw the Indo-Fijian community as having significant electoral potential. In legislating the ALTA, the Alliance government

\footnotetext{
"The Emergence of Party Politics in Fiji," pp. 40-47.

${ }^{257}$ Notably the reform of the ALTO to the ALTA came soon after the signing of the Sugar Protocol, in the European Union's (EU) 1975 Lomé Convention. This deal guaranteed the Fijian sugar industry preferential access to European markets and subsidy payments comparable to the EU's own internal price for sugar per tonne. See discussion in preceding chapter.
} 
sought the goodwill of the Indo-Fijian community at the expense of alienating groups within the Pacific-Fijian community, especially the chiefly elite.

The structure of the Fiji's land-tenure system and the lease agreements governed by the NLTA favours the native land owners (for the differences between ALTA and NLTA see Table 3 and note discussion of lease rents in Chapter Three). Under the NLTA, chiefly elites, through the Native Land Trust Board (NLTB) determine the terms of lease agreements, the value of rent and premiums to be paid. Although agricultural native land leases fell under the ALTO (that favoured leaseholders), its terms were up for review after independence. Formalisation of agricultural land leases under the ALTO benefited IndoFijian communities and demonstrated Mara's commitment to integrating their interests in the governing of the country. Thus, legislating the ALTA provided Mara a policy tool to make electoral gains.

It is significant to note that in choosing to reform the ALTO Mara was altering Fiji's landtenure system and, thus, needed support from a majority of the eight Senators nominated by the Council of Chiefs. Although the NLTB publicly opposed formalisation of the ALTO, as it severely disadvantaged the NLTB and native land owners, these Senators still voted for the reform. Despite the chiefs' material interests in eliminating the ALTO, Mara had sufficient control over his chiefly peers to provide him the necessary political support to formalise it.

Fiji's illiberal land-tenure system and the legislation that governs lease agreements are highly political as they are central determinants of the structure of the economy. Passage of the 1976 ALTA formalised the differences between agricultural and non-agricultural leases, as the ALTO had provided. The ALTA formalised the provisions of the ALTO in the post-independence legal environment and altered the land-tenure system in a highly political manner. The ALTO in 1966 removed all new agricultural leases from the control of the NLTB and its arbitrary system of rent setting, into one formalised system of fixed land valuation and lease rents. In doing this, the ATLO had decreased the chiefly elite's control over native land.

Table 3: The differences between ALTA and NLTA lease agreements

Terms and Conditions ALTA NLTA 


\begin{tabular}{|l|l|l|}
\hline Lease Tenure & $\begin{array}{l}\text { Minimum: 30 years } \\
\text { Maximum: indefinite, but the } \\
\text { 30 years has become a de } \\
\text { facto maximum }\end{array}$ & $\begin{array}{l}\text { Minimum: of 5 years } \\
\text { Maximum: 99 years } \\
\text { Most leases a rolling 5-10 years }\end{array}$ \\
\hline Rent & $\begin{array}{l}\text { 6\% of the Unimproved } \\
\text { Capital Value (UCV) }\end{array}$ & NLTB sets a "market" rent \\
\hline Premium & No premium & Premium paid \\
\hline Renewal of Lease & No right of renewal & $\begin{array}{l}\text { Right of renewal subject to } \\
\text { NLTB's consent }\end{array}$ \\
\hline Settlement of Disputes & $\begin{array}{l}\text { By the Fiji Sugar Industry } \\
\text { Tribunal }\end{array}$ & By independent arbitration \\
\hline Choice of land utilisation & Tenant determined & As stipulated in the Act \\
\hline
\end{tabular}

Source: Native Land Trust Board, 'Distinctions Between ALTA \& NLTA

The difference between the NLTA, the ALTA and their preceding ordinances are vast, see Table 3. As explained in the preceding chapter under NLTA, the NLTB determines (on behalf of native land owners) the value of rents and premium payment and sets the financial terms of all individual non-agricultural lease rents. ${ }^{258}$ In contrast, under the ALTA, agricultural lease rents have a fixed value, set by the Committee of Valuers of which $6 \%$ is charged as annual rents and have no premium. ${ }^{259}$ Another key difference between them is the NLTA non-agricultural leases have a short minimum lease period of 5 years ${ }^{260}$ with a capped maximum of 99 years, ${ }^{261}$ while the ALTA lease agreements have a longer minimum lease length of 30 years, and no maximum. ${ }^{262}$ The passing of the ALTA proved to be an immensely political decision favouring many, predominantly Indo-Fijian leaseholders, at the expense of chiefly influence.

In reviewing the ALTO, the Alliance government was not obliged to formalise the ordinance as they had done when formalising the $\mathrm{NLTO}^{263}$ into the NLTA. Instead, it had the option to override the ALTO with an amendment to the NLTA, extending the NLTA to cover agricultural lease agreements. However, it chose not to do so. Instead, it preserved the ALTO's terms, which were favourable to agricultural farmers, predominantly Indo-

258 Native Land Trust Act 1970. Part 2, Section 13

259 Agricultural Landlord and Tenant Act 1976. Part II, Section 14(1)

260 The minimum NLTA is stipulated in this document: Native Land Trust Board, "Distinctions between Native Land Trust Act \& Agricultural Landlord and Tenant Act," (Native Land Trust Board). But a minimum NLTA lease term is not specified in the NLTA itself.

261 Native Land Trust Act 1970. Part IV, Section 33(6). ___ " "Distinctions between Native Land Trust Act \& Agricultural Landlord and Tenant Act."

262 Although ALTA and NLTA both have dates subsequent to their original passing, 1978 and 1985 respectively, these were not the dates of the original legislation. The terms of ALTA were legislated by Act No. 35 of 1976 and the terms of NLTA were legislated by the issuing of Legal Notice 112 of 1970. Agricultural Landlord and Tenant Act 1976. Part II, Section 6(b). Native Land Trust Board, "Distinctions between Native Land Trust Act \& Agricultural Landlord and Tenant Act."

263 The terms of the 1940 NLTO had been formalised as an Act by Legal Notice 112 of 1970. 
Fijian sugar farmers. This move added weight to Mara's credibility as an advocate for the Indo-Fijian community.

While Mara entered the 1977 election expecting to consolidate the Alliance Party's dominance in Fijian politics, the outcome proved much different. In seeking to extend its electoral appeal by passing the ALTA, the Alliance government achieved only electoral overreach. Although legislating the ALTA elicited support from Indo-Fijian communities, and bolstered the claims that the Alliance Party could construct policy across ethnic political divides, it alienated conservative Pacific-Fijians, splintering the Alliance Party's core constituency.

\section{The March 1977 election}

The March 1977 general election was inconclusive, resulting in a constitutional quagmire. The situation tested the strength of both Fiji's electoral institutions and the Governor General's impartiality as the upholder of the rule of law and the electoral institutions. The opaque nature of the electoral result and the odd set of events that followed paved the way for the Alliance Party's return to power.

The chiefly elite's dominance within the polity had led to one of the highest chiefs, Ratu Sir Joji Kadavulevu George Cakobau, ${ }^{264}$ holding the office of Governor General. Cakobau was responsible for upholding the system of checks and balances inherent in the Fijian constitution, yet his response to the indecisive electoral result was to disregard it completely. Although this was strictly constitutional, it did call into question his neutrality, and provided the first glimpse of the authoritarian reality underlying Fiji's post-colonial political institutions.

Having overseen a peaceful transition to independence, and governed Fiji by promoting multiculturalism for nine years, ${ }^{265}$ Mara was defeated at the polls. The National Federation Party won a plurality with 26 of the 52 seats in the House of Representatives, with the

\footnotetext{
${ }^{264}$ Cakobau was one of the highest chiefs in both Fijian colonial and post-colonial history. He was a paramount chief, holding the traditional titles of Vunivalu of Bau and Tui Levuka, and was a member of the Council of Chiefs between 1938 and 1972, until his appointment as Governor General in 1973.

265 Although two of these years were before independence, Mara possessed vast influence having been the political leader of Fiji between the 1968 election and independence in 1970.
} 
Alliance Party winning 24 seats and the Fijian Nationalist Party the remaining two. Mara's attempt, with the passage of the ALTA, to build a cross-ethnic coalition and reach out to the Indo-Fijian community, in fact isolated groups within the Pacific-Fijian community. The Fijian Nationalist Party, led by Sakeasi Butadroka, ${ }^{266}$ emerged in $1974^{267}$ challenging the Alliance Party's position as the protector of Pacific-Fijian interests and the chiefly system. ${ }^{268}$ At this election, the Alliance Party's vote was squeezed from both sides. ${ }^{269}$ Its vote in Pacific-Fijian communal electorates fell from $83 \%$ in 1972 , to $67 \%$ in $1977 .{ }^{270} \mathrm{~A}$ large proportion of these lost votes went to the Fijian Nationalist Party, the first election it contested, which won $25 \%$ of the vote in Pacific-Fijian communal electorates. ${ }^{271}$ Conservative Pacific-Fijian communities abandoned Mara, believing he had marginalised their interests and threatened chiefly paramountcy. The Alliance Party also saw its vote in Indo-Fijian communal electorates drop from $24 \%$ in 1972 , to $16 \%$ in $1977,{ }^{272}$ a result of the National Federation Party's success in achieving electoral unity within the Indo-Fijian community.

Although the National Federation Party achieved a plurality of the vote, it did not form a government. The National Federation Party was one seat short of a majority in the house, while the Alliance Party needed three seats to form a government. This left the formation of a majority coalition government limited to two combinations. The political distance between National Federation Party and the Fijian Nationalist Party meant that a coalition between these two was not viable, leaving a coalition between the two largest parties as the only plausible solution. Mara, however, rejected Koya's overtures to negotiate such a deal, precipitating instead a constitutional crisis, in which Governor General Cakobau held the power to determine the solution. ${ }^{273}$

After the election, the National Federation Party met to elect a formal leader, having

266 Butadroka was elected as an Alliance Party Member of Parliament in 1972. He left the Alliance in 1974, forming the Fijian Nationalist Party. Ahmed Ali, "The Fiji General Election of 1977," The Journal of Pacific History 12, no. Part 4 (1977): p. 193.

${ }^{267}$ While the Fijian Nationalist Party emerged before the formalisation of ALTO, it believed its claims of Mara margainalising Pacific-Fijian interests were vindicated by the passing of ALTA.

268 In October 1975, Butadroka had unsuccessfully moved a parliamentary motion requesting the Government repatriate all Fijian citizens of Indo-Fijian ethnicity. Although this motion was unsuccessful, it provided Butadroka with extensive radio and press coverage. Ali, "The Fiji General Election of 1977," p. 193.

269 Ibid.: p. 190, 98.

270 Ibid.: p. 191.

271 Ibid.

272 Ibid.

${ }^{273}$ Norton, Race and Politics in Fiji, p. 118. 
campaigned without one. Dr Siddiq Koya was elected leader, but it took two ballots to do so, displaying disunity within a party that would later rupture into factions. ${ }^{274}$ After the election of Koya as leader of the National Federation Party, despite it only holding 26 seats, Cakobau invited Koya to form a government and he made an appointment to do so, and departed for Government House to be sworn in. Yet, in the intervening 45 minutes between agreeing to swear Koya in and his arrival at Government House, Cakobau, called Mara to his residence and appointed him interim Prime Minister. ${ }^{275}$ Cakobau then informed the people of Fiji of his actions:

"In the recent elections the people of Fiji did not give a clear mandate to either of the major political parties. It therefore became the duty of the Governor General under the Constitution to appoint as Prime Minister the member of the House of Representatives who appeared to him best able to command the support of the majority of the House...In compliance with the Constitution and acting in his own deliberate judgement, the Governor General has accordingly appointed Ratu Sir Kamisese Mara as Prime Minister."276

Rather than pressure Mara to work with Koya to form a government, or simply allow Koya to test his support in the parliament, Cakobau had chosen to effectively pre-empt the electoral results. Although the Alliance Party was defeated, Cakobau's actions allowed it to maintain control of government. If Mara had been the statesman he proclaimed himself to be, he could have chosen to acknowledge the people's will by working with Koya to maintain the legitimacy of Fiji's electoral institutions. Instead, he supported Cakobau's actions, which although constitutionally permissible, undermined the legitimacy of Fiji's institutions and permanently disrupted the potential for parties not backed by the chiefly elite to attain government.

Cakobau's solution to the constitutional crisis raised also questions about the ability of high chiefs in the highest constitutional positions to act impartially in protecting

\footnotetext{
274 The first ballot was a tie of 13 each between Koya and General Maitoga. The second ballot resulted in 14 votes for Koya and 12 for Maitoga. Yash Ghai and Jill Cottrel, Heads of State in the Pacific: A Legal and Constitutional Analysis (Suva: Institute of Pacific Studies of the University of the South Pacific, 1990), p. 175.; Ali, "The Fiji General Election of 1977," p. 200.

275 Ghai and Cottrel, Heads of State in the Pacific: A Legal and Constitutional Analysis, p. 175.; Ali, "The Fiji General Election of 1977," p. 200.

276 Ali, "The Fiji General Election of 1977," p. 201.
} 
constitutional and electoral institutions. As one of the highest chiefs in Fiji's history, the reassertion of the chiefly-backed Alliance Party as government, seemed to serve Cakobau's interests as much as that of any other high chief.

After bypassing the March electoral result and reappointing Mara, Cakobau called a second general election for September 1977. He proclaimed this the only workable solution to the constitutional crisis. The actions of the Governor General returned the incumbent government, which subsequently ruled for another ten years. The lack of a change of government over this time, and in particular as a result of the March 1977 election, further compounded problems regarding the legitimacy of Fiji's electoral institutions.

Furthermore, the National Federation Party's inability to form a government after the first election exacerbated the emergence of internal factions and undermined its electoral credibility, and the credibility of any alternative to chiefly dominance, as was borne out in subsequent election results.

\section{The September 1977 election}

Following the bypassing of the March election results, Mara quickly reasserted himself as the foremost political representative of the Pacific-Fijian community. Subsequently, the Alliance Party won a landslide victory in the September election claiming 36 of the 52 seats in the House of Representatives. This was mainly due to Cakobau's solution to the constitutional crisis posed by the March election result, which undermined the electoral appeal of both the National Federation Party and the Fijian Nationalist Party. The crisis had demonstrated to Pacific-Fijians that without political unity, the maintenance of chiefly interests could not be guaranteed. This led to Pacific-Fijian voters returning to the Alliance Party and it regained the two seats lost to the Fijian Nationalist Party, who won no seats at the September 1977 general election. It also regained seats lost to the National Federation Party in March 1977. Notably, in the Pacific-Fijian communal electorates, the Alliance Party's vote rose from 65\% in March 1977, to $81 \%$ in September. ${ }^{277}$

For Mara, the scare of March 1977 election hardened his political resolve for another decade, during which he retained control of government throughout. Although he

${ }^{277}$ Norton, Race and Politics in Fiji, p. 188. 
continued to publicly refer to his multicultural experiment, Mara never again attempted to court the Indo-Fijian vote on the scale of the ALTA. At the same time infighting within the National Federation Party, arising from its inability to form a government, partnered with intra-party generational change, hindered the party's organisation and electoral appeal throughout the following decade.

The events of 1977 also changed the character of politics in Fiji. Henceforth, ethnic cleavages framed electoral results, with only voter turnout determining electoral outcomes. The events of March 1977 demonstrated that the distribution of electoral seats amongst political parties was effectively 'frozen', while ethnicity was the primary cleavage within the polity. This ongoing stasis was entrenched by Mara's failed attempt to construct an electoral coalition across ethnic groups, followed by Koya's inability to form a coalition government. It soon became apparent that a new form of politics was needed if the Alliance Party's electoral dominance was to be challenged.

\section{The demise of electoral governance 1987-1990}

Ten years after the constitutional crisis threatened the chiefly elites control of government, electoral institutions once again threatened their dominance at the general election of 1987. In that election, the Labour Party-National Federation Party Coalition ${ }^{278}$ won an outright majority, securing 28 seats to the Alliance Party's $24 .{ }^{279}$ Unlike in March 1977, the coalition parties held a majority of seats and a clear mandate to govern, resulting in the formation of Fiji's first government not backed by the chiefly elite. Although the Pacific-Fijian chiefly elite still controlled the economy, and Pacific-Fijian chiefs held the offices of President and Vice-President, as well as a majority of the seats in the Senate, the chiefs had lost control of government. The transition to a new government, only Fiji's second government after independence, created a tension between elected government and the chiefly elite that

\footnotetext{
${ }^{278}$ Here the National Federation Party and the Fiji Labour Party campaigned together as a coalition. Their coalition agreement was finalised in December 1986 and on the ballot the parties were listed as one. Of the 52 candidates selected to contest the election, 37 were from the Labour Party. However, many Labour candidates were selected for unwinnable seats. Following the election, exactly half of the coalition's MPs were Labour members, although the majority of Cabinet members came from the Labour Party. I will refer to the government elected in March 1987 as the 'Labour-National Federation Coalition Government'. Lawson, The Failure of Democratic Politics in Fiji, p. 253.; Brij V. Lal, "Before the Storm: An Analysis of the Fiji General Election of 1987 " Pacific Studies 12, no. 1 (1988): p. 73-79.

${ }^{279} \mathrm{Lal}$, "Before the Storm: An Analysis of the Fiji General Election of 1987 ": p. 71.
} 
retained overwhelming influence in both the economy and society. Events following the 1987 election result revealed the authoritarian institutional infrastructure underlying Fiji's political economy.

The Labour-National Federation coalition's electoral majority created a challenge for the chiefly elite. Unlike 1977, where Cakobau used his constitutional powers to bypass the National Federation Party's electoral 'victory', the chiefly elite possessed no legal means to remove the Labour-National Federation government from power. However, while the chiefly elite had no formal powers to inhibit the government's formation, their significant influence within the Pacific-Fijian community remained. As Fiji's electoral institutions were yet to produce a change of government, chiefly support was crucial if the Labour-National Federation coalition was to translate its electoral success into a wide mandate from all Fijians to govern.

The events that followed the 1987 election further revealed the nature of the power structures underlying Fiji's political institutions. Seventeen years of Alliance Party rule had entrenched the chiefly hierarchy's dominance of the polity. This had negated the presence of electoral results, leaving electoral institutions somewhat ill prepared to observe the peoples' demands for a change in government. The chiefs' response to the 1987 general election is the most documented feature of Fiji's history: a coup d'état.

The seemingly unending rule of the Alliance Party had rendered Fiji's electoral institutions superfluous. Although, the Labour-National Federation government had attracted voters from across Fiji's ethnic communities, its electoral mandate had little legitimacy in the eyes of chiefly elites. The chiefs were unwilling to tolerate a government beyond their authority and control. Consequently, the Labour-National Federation government, sworn in on 13 April 1987, lasted only a month. Its sudden removal would also see Fiji’s constitution rewritten to entrench chiefly privilege and ensure that electoral institutions could never again undermine chiefly authority again. The overthrow of government in 1987 exposed a parallel set of authoritarian institutions controlled by the chiefly elite.

This section is split in three parts. First, it examines the arrival of the Labour Party and the impact this had on political cleavages within the polity. Second, it then explains the 1987 general election and the subsequent coup. The overthrow of government in 1987 exposed 
a parallel set of authoritarian institutions controlled by the chiefly elite. Finally, it addresses how the 1990 constitutional reform served to entrench Pacific-Fijian advantage within electoral institutions, to guarantee chiefly-backed governments.

\section{A change of government}

The general election of 1987 brought a new form of politics to Fiji. Mara's rule was over and a new political entity, the Fiji Labour Party, in a coalition government with the National Federation Party, ended the Alliance Party's political dominance. Established in 1985, the Labour Party presented a new of politics to Fiji, one that spoke of class $^{280}$ instead of race. ${ }^{281}$ During the 1987 election campaign, Labour Party leader Dr Timoci Bavadra ${ }^{282}$ had emphasised that the individual's democratic right to vote, did not mean a compulsion to vote for a chief, rather, "it was a free choice." 283 Throughout their campaign, the Labour Party agued chiefs had manipulated politics within the Pacific-Fijian community and encouraged Pacific-Fijians to think beyond communalism when casting their vote.

The arrival of the Labour Party redrew political cleavages, and altered the rules of electoral campaigning in Fiji. ${ }^{284}$ Its success also demonstrated the viability of political coalitions across ethnic communities. The Labour Party spoke beyond racial identities, and Mara's multicultural experiment, in doing this they identified the authoritarian hierarchy of chiefly elites and the power of big business as the real causes of Fiji's ills. This new form of politics transcended ethnic divisions, and appealed to those disaffected by Mara's arbitrary

280 A distinction must be drawn between race and ethnicity when discussing the characteristics of the Fijian polity. Historically in Fiji, race and ethnicity have been closely associated as defining political ideas. As Robert Norton has documented, racial politics is the manipulation and politicisation of ethnic differences by political elites whose interests have been in the division of the two predominant ethnic groupings in Fiji. Norton, Race and Politics in Fiji.

281 Mahendra Chaudhry, The Rise of the Fijian Labour Party (Sydney: H. V. Evatt Memorial Foundation, 1987).; Brij V. Lal, "Postscript: The Emergence of the Fiji Labour Party," in Politics in Fiji: Studies in Contemporary History, ed. Brij V. Lal (North Sydney, New South Wales: Allen \& Unwin, 1986).

282 Bavadra was a medical doctor from a middle class background. He typified many Pacific-Fijians who had risen to prominence in the civil service in the period following independence. As the head of his Tokatoka (sub-lineage or extended family) he was a low-ranking chief but, like many Pacific-Fijians from western Fiji, he chose not to use his title of Ratu. Lal, "Rhetoric and Reality: The Dilemmas of Contemporary Fijian Politics," p. 99.

283 Brij V. Lal, Broken Waves: A History of the Fiji Islands in the Twentieth Century, Pacific Islands Monograph Series (Honolulu: University of Hawaii Press, 1992), p. 337.

284 Although due to their combined campaign it is difficult to ascertain the relative effectiveness of the Labour Party's campaign compared to the National Federation's, extant literature emphasises on the new politics brought by the Labour Party and the importance of its discourse in shaping election debate. Lawson, The Failure of Democratic Politics in Fiji; Robertson and Tamanisau, Fiji: Shattered Coups. 
exertion of power, building electoral support in both Indo-Fijian and urban Pacific-Fijian communities. ${ }^{285}$

The arrival of this new politics of class had freed electioneering from its demographic stalemate. Previously, no political party had been able to attract significant support from multiple ethnic communities and an ethnic demographic majority had translated to an electoral majority as long as political unity was maintained within that ethnic community. The Alliance Party had achieved high socio-political cohesion by institutionalising the chiefly system within the party, with high chiefs represented throughout its ranks. By imposing this formal social hierarchy within the Party, it facilitated disciplined ethnic voting amongst Pacific-Fijians, making political unity within this community straightforward.

The problem for the Labour-National Federation government, ${ }^{286}$ was that although it possessed electoral legitimacy, a clear mandate and a willingness to share power across ethnic communities, it lacked chiefly support, and this undermined its longevity. Because a majority of the coalition's MPs were of Indo-Fijian ethnicity, the coalition elevated PacificFijian MPs to cabinet to demonstrate its commitment to cross-ethnic power sharing, and to bolster its legitimacy in the eyes of Pacific-Fijians. It appointed Labour Party leader, Dr Timoci Bavadra, a Pacific-Fijian as Prime Minister along with six other Pacific-Fijians MPs from the Labour Party as Ministers.

The 1987 election brought Fiji's first change of government and, consequently, raised tensions that would undermine the legitimacy of Fiji's electoral institutions. Mara acknowledged his defeat, saying: "You have given your decision. That decision must be accepted. While I am naturally disappointed...I am proud that we have been able to demonstrate that democracy is alive and well in Fiji." ${ }^{287}$ Yet, despite this rhetoric, chiefs' were questioning the sustainability of the new government, thus ensuring that the hope Mara had displayed in Fijian democracy and the rule of law would be premature. The eventual usurping of government in 1987 provides the second and clearest illustration of the continuing authoritarian structure of Fijian politics.

\footnotetext{
285 Ravuvu, The Facade of Democracy: Fijian Struggles for Political Control 1830-1987, p. 77.

286 Thirteen of the seventeen cabinet members were from the Labour Party. Lal, Power and Prejudice: The Making of the Fiji Crisis, p. 12.

287 Norton, Race and Politics in Fiji, p. 133.
} 


\section{The reassertion of chiefly control over government}

On 14 May 1987, Fiji's democratic facade came crashing down. Lieutenant-Colonel Rabuka, the third-in-command of the Fijian Royal Military Forces (FRMF), led a group of armed soldiers into the parliamentary complex in Suva and ordered sitting MPs to evacuate Parliament. The 1987 electoral defeat was too harsh a reality for chiefs to tolerate.

The loss of direct control of government was considered unacceptable, forcing the chiefs to usurp the new government and override the constitution and rule of law. This action proved electoral processes would only be permitted to determine the composition of government if they reaffirmed the chiefly-backed Alliance Party's rule. If 1977 had indicated a weakness of Fiji's electoral institutions because of the institutional control of the chiefly elite, the events of 1987 made this relationship unmistakable.

A clear relationship existed between the chiefly elite and the protagonists of the 1987 coup, and indeed considerable evidence demonstrates that the chiefly elite orchestrated the overthrow itself. In his authorised biography, ${ }^{288}$ Rabuka illustrated how he played golf with Mara in the days leading up to the coup. In speaking of the problem of the LabourNational Federation government, Rabuka recounts the following incident: "Mara looked at him carefully and said, quietly, 'The only way to change the situation is to throw the constitution out the window.' Rabuka replied, 'I can do that sir." 289 Throughout the coup, Rabuka made clear his desire to reassert the chiefs as Fiji's highest authority and on 14 May Rabuka stated, "Everyone is welcome to come and live here as our guest, as long as the [Pacific-] Fijian[s] run the nation." ${ }^{290}$ Such rhetoric highlights a Taukei Movement ${ }^{291}$ view that the chiefly elite must remain the highest and exclusive political authority in Fiji.

288 Sharpham, Rabuka of Fiji: The Authorised Biography of Major-General Sitiveni Rabuka.

289 Ibid., p. 104. Mara disputes these events ever took place arguing that he never gave consent to Rabuka to undertake the coup, although he did admit to playing golf with Rabuka before the coup. Michael Field, Tupeni Baba, and Unaisi Nabobo-Baba, Speight of Violence: Inside Fiji's 2000 Coup (Auckland: Reed Publishing, 2005), p. 39.

290 Dean and Ritova, Rabuka: No Other Way, p. 14.

291 The Taukei political movement formed soon after and the March 1987 general election, and as a result to it. It was formed by members of the defeated Alliance Party and allied to chiefly interests, in reaction the Alliance's loss. The Taukei movement constituted of a wide assortment of Pacific-Fijian variously opposes to the 1987 Labour-led government and staunchly committed to its overthrow. It was organised by former Alliance minister, Apisai Tora and senator Jona Qio. Prominent members of the Taukei Movement included Alliance ministers, Filipe Bole and Qoronisau; Alliance Party MP, Taniela Veitata; Alliance Party General Secretary, Jone Veisamasama; and Mara's son Ratu Finau Mara. Lal, "Before the Storm: An Analysis of the Fiji General Election of 1987 ": p. 72.; — , "Rhetoric and Reality: The Dilemmas of Contemporary Fijian Politics," p. 97, Ravuvu, "The Fijian Chiefly System and the Democratic Process."; Lawson, The Failure of Democratic Politics in Fiji, p. 256. 
Rabuka expressed a number of motivations for the coup: he claimed he was on a mission "that God has given me" to ensure "the survival of the [Pacific-] Fijian race."292 The most telling justification came in his conception of the role of the chiefs in the governance of Fiji, asserting:

\begin{abstract}
"When a political party loses, and that party is the sole and final guarantor of your values, you would be forced to do something about it...I am a commoner and to see my high chief [Mara] being accused of corruption with no proof... [and] the language used against him, I will never accept nor would any right thinking [Pacific-] Fijian.,203
\end{abstract}

Writing in 2000, Rabuka reflected, "The objective of the 1987 coups as confirmed by the Great Council of Chiefs on 20 May 1987, was to change the constitution in favour of the indigenous Fijians...The aim was...assertion of the indigenous Fijian identity and the leadership of the role of the chiefs." ${ }^{294}$ During the coup, as seen in his justification, Rabuka failed to acknowledge constitutional legitimacy, democratic process, or the rule of law. From the earliest days after the coup, Rabuka asserted that Fiji's chiefly elite is the ultimate focus of political loyalty for Pacific-Fijians. ${ }^{295}$ The absence of chiefly support for the Labour-National Federation government meant it was doomed to fail from its inception. ${ }^{296}$ One dominant rationale was clear, the restoration of chiefly authority at the top of Fiji's political institutions.

Following the election of the Labour-National Federation government, anti-government rhetoric quickly became commonplace within conservative Pacific-Fijian communities. The actions of chiefs' following the coup provide insight into their opinions of the overthrow. At a political Taukei Movement meeting after the coup, a prominent chief of Kubuna stated, "Ratu Mara's government has been defeated and so all the chiefs in the land have been defeated. ${ }^{, 297}$ Governor General Ratu Sir Penaia Kanatabatu Ganilau ${ }^{298}$ was the only

\footnotetext{
292 Dean and Ritova, Rabuka: No Other Way, p. 11.

${ }^{293}$ Norton, Race and Politics in Fiji, p. 133.

294 Sitiveni L. Rabuka, "The Fiji Islands in Transition: Personal Reflections," in Fiji before the Storm: Elections and the Politics of Development, ed. Brij V. Lal (Canberra: Asia Pacific Press, Southwood Press Pty Limited, 2000), pp. 12-13.

${ }^{295}$ Lawson, Tradition Versus Democracy in the South Pacific: Fiji, Tonga and Western Samoa, p. 53.

${ }^{296}$ Lal, "Rhetoric and Reality: The Dilemmas of Contemporary Fijian Politics," p. 99.

${ }^{297}$ Norton, Race and Politics in Fiji, p. 139.
} 
high chief to condemn the overthrow of the Labour-National Federation government publicly. However, even his opposition evaporated quickly when he realised he was isolated amongst his chiefly peers. Despite earlier rhetoric, Mara was one of the first to publicly support Rabuka's actions and then join the transitional cabinet. Most significantly, the Council of Chiefs endorsed Rabuka's actions overwhelmingly. High chiefs interests in maintaining their supremacy over the electoral desires of constituents, directly aligns with those of the protagonists of the coup.

Before the 1987 election campaign, the Labour Party had outlined its desire to reform the NLTB, to make it more efficient and responsive to both native land owners' needs and tenants' concerns. These planned reforms would have directly threatened chiefly interests. At the Labour Party's first annual conference Bavadra stated, "My concern is that the NLTB has become too much of the tool of certain vested interests in this country and that all too often steps taken by the NLTB are not in the best interests of the majority of landowners themselves." He added:
"The NLTB must be democratised so that it comes to serve the interests of all [Pacific-] Fijians and not just the privileged few and their business associates... I feel that we must discuss means to achieve a more equitable distribution of income from rent within the landowning group as well. ${ }^{, 299}$

Leading up to the 1987 election, the Labour-National Federation Coalition suggested the establishment of a National Lands Commission. It proposed this institution should comprise of representatives from the government, native land owners and tenants, and that would watch over the NLTB's operations, keeping it accountable to all. The Alliance clearly opposed any reform to the NLTB, with Mara using coded rhetoric to appeal to PacificFijian's insecurities about native land ownership saying, it "could lead to a slipping ${ }^{300}$ of

\footnotetext{
${ }^{298}$ Ganilau was appointed Governor General in 1983. Ghai and Cottrel, Heads of State in the Pacific: A Legal and Constitutional Analysis, p. 242.

${ }^{299}$ It is notable that Bavadra himself had a vested financial interest as a chief, albeit a low-ranking chief, and recipient of lease payments to maintain the system of lease distribution. Timoci Bavadra, "Text Address by the Newly Elected President of the Fiji Labour Party," in Fiji Labour Party 1st Annual Conference (Suva: South Pacific Forum, 1986).; Lal, "Before the Storm: An Analysis of the Fiji General Election of 1987 ": p. 87.

300 Within this context 'slipping' is used to imply the potential loss of control of native land through land reform.
} 
native land." ${ }^{301}$ Speaking more aggressively about the proposed reform, Alliance Party Deputy Prime Minister Ratu David Toganivalu stated, "What they do not know is that when they touch the land it is dynamite, the world will explode." ${ }^{\prime 302}$ This proposal to reform the distribution of rental earnings from native land leases challenged the foundation of the chiefly elites' material power and contributed to the urgency in usurping the new government.

During the 1987 campaign, the Alliance Party's advertising also hinted at the chiefs' power over the electoral system. An Alliance Party newspaper advertisement berating Bavadra's political experience read, "Bavadra has never been in Parliament. He has no experience. He has no influence. The Council of Chiefs do not listen to him. The international scene where we sell our sugar has never heard of him. He cannot get renewal of leases for our farmers. ${ }^{, 303}$ It is notable that this Alliance advertisement cited the two key pieces of the economy, which had served to keep the chiefly elite's dominance over Fijian society: EEC s sugar subsidies and land tenure.

After the appointment of the Labour-National Federation government, a number of prominent Pacific-Fijians propagated claims aimed at undermining the Government. For example, it was claimed the government did not possess a broad-based coalition of support as only $9.6 \%$ of Pacific-Fijians had voted for the coalition government, while $15.1 \%$ of Indo-Fijians had voted for the Alliance. ${ }^{304}$ Government objectors also questioned its legitimacy, as it had not won a majority of the popular vote. Although it won four seats more than the Alliance, the Labour-National Federation coalition had achieved only $46 \%$ of the popular vote, compared with the Alliance's 49\%. These claims argue past the reality of Fiji's electoral system, which did not use the popular vote to determine the distribution of constituency. Rather, it used a first-past-the-post method to determine the distribution of constituent seats in the lower house of Parliament. Under this system, the LabourNational Federation coalition had won a majority, with 28 seats. In reality, these objections were not to do with the system itself, but simply about the Indo-Fijian presence in Government.

After two decades of uninterrupted chiefly domination of government, the 1987 election

\footnotetext{
${ }^{301}$ Lal, "Before the Storm: An Analysis of the Fiji General Election of 1987 ": p. 87.

302 - Power and Prejudice: The Making of the Fiji Crisis, p. 27.

303 _

304 Ibid.: p. 91.
} 
result revealed chiefs' insecurities about their place in Fijian society. The chiefly elite's apparent crisis regarding its lost control of government was heightened by the complete lack of alternation of government. This was further exacerbated by the extent to which the elite had been institutionalised within Fiji's political institutions. Furthermore, the elite was not only constitutionally entrenched, but possessed material advantages over the rest of Fijian society and controls over the economy. The Alliance Party's continual electoral success, and its housing of high chiefs within its ranks, had provided further political legitimacy to the tribal hierarchy. To ensure a peaceful transition to independence, high chiefs filled the ranks of prominent political positions across the executive and legislature. However, after this transition, the chiefly hierarchy was never detached from the ranks of the Alliance Party. Rather, as the Alliance Party solidified its unchallengeable position as the dominant political force in Fiji, the chiefs solidified their position at the apex of Fijian society. The chiefly elite believed the Alliance Party's loss, and particularly its loss of government undermined the paramountcy of their social hierarchy. Many chiefs feared that electoral competition and uncertainty would disrupt the staid certainty of the traditional social hierarchy.

The failure to decouple the chiefly social hierarchy from Fiji's electoral institutions left them in tension with one another. The location of pre-colonial social leadership in Fiji's political institutions satisfied conservative Pacific-Fijians, but it created problems for the maintenance of electoral institutions. In the short term, the placement of high chiefs in the Alliance Party initially legitimised the new political institutions in the eyes of conservative Pacific-Fijians. Although this ensured chiefly control of government, it created a perception within some Pacific-Fijian communities that the legitimacy of these electoral institutions derived only from them being filled by chiefs, specifically, those within the Alliance Party. So when the Alliance Party and Mara lost, the legitimacy of the electoral institutions in the eyes of some Pacific-Fijians evaporated. Those whose political identifications had been manipulated by communal politicking could not comprehend Fiji being run by non-chiefs. This group included both chiefly elites and rural tribal based Pacific-Fijians. Some urban Pacific-Fijians on the other hand, saw beyond this frigid political identification. In addition to this, lengthy dominance of electoral politics by the Alliance Party had also eroded the legitimacy of the political institutions in the eyes of the Indo-Fijian community. 
Alongside this, the restriction to chiefly elites of high constitutional positions, such as Senate seats, and the top positions within the Alliance Party, limited the development of new leadership within the Pacific-Fijian community for those without chiefly title. In failing to liberalise access to the highest levels of governance, the chiefly elite found themselves in conflict with 'common' Pacific-Fijians who sought political representation and authority but lacked a hereditary title. Throughout the 1987 election campaign, Bavadra, the Labour Party, leader addressed this conflict: "We respect the chiefly system but condemn the manipulation of respect for chiefs for political ends...the chiefly system should be separated from democratic politics. ${ }^{, 305}$ It became rapidly apparent that the integration of the chiefly elite into the electoral process and true democratisation were not compatible.

\section{Rewriting chiefly institutionalised privilege}

The 1990 constitutional reform embedded chiefly authority and Pacific-Fijian advantage more deeply within Fiji's political institutions. The March 1987 coup solved the short-term crisis created by the Labour-National Federation coalition's victory and the chiefs' loss of executive power. A new constitution was needed to entrench the political dominance of the chiefly elite and mitigate any risks that electoral institutions presented to this elite. The constitution was redrawn to ensure electoral processes would never again threaten chiefly control of government as they had in 1987, and nearly had in 1977.

The new constitution enhanced Pacific-Fijians' disproportionate advantage over political institutions and guaranteed chiefly control over electoral institutions. While Rabuka wanted immediate constitutional reform, it did not come until 1990. A week after the first coup he pronounced, "The sooner we accept a new constitution the better, for we will be preserving what is dear to our hearts - the chiefly system, our land and Christianity."306 Established by the post-coup interim government, an advisory committee, chaired by Dr Asesela Ravuvu, set about drafting reform of the constitution. The advisory committee sent its proposals to the interim cabinet, which then passed it on to the Council of Chiefs, which explicitly approved the reforms, before was decreed by Presidential edict. ${ }^{307}$ The role of the Council of Chiefs in drafting Fiji's 1990 Constitution was yet another demonstration

\footnotetext{
305 Norton, Race and Politics in Fiji, p. 134.

306 Ibid., p. 139.

${ }^{307}$ Lal, Islands of Turmoil: Elections and Politics in Fiji, p. 235.
} 
of the intention to completely entrench the chiefly elite's control of political institutions.

Representatives from Fiji's political parties, excluded from the interim government, accepted the terms of the 1990 Constitution unenthusiastically as a necessary compromise for the transition back to electoral governance in 1992. If electoral processes, inherently unpredictable, were to determine the composition of Fiji's parliament, then Parliament's role in determining political outcomes had to be restricted. Notably, the new constitution further entrenched racial politics by removing all national seats from the legislature and leaving only communal seats, of which Pacific-Fijian seats were the majority. Again, the institution that embodied chiefly authority, the Council of Chiefs, received increased powers over the polity at the expense of the democratic process.

The 1990 Constitution also proclaimed the unambiguous supremacy of the Pacific-Fijian chiefs' interests and their institutions. ${ }^{308}$ Under the new constitution, the House of Representatives comprised 70 seats: 37 seats for Pacific-Fijians, 27 for Indo-Fijians, 5 for 'General Voters' and 1 for Rotumans. ${ }^{309}$ Meanwhile, the Senate had a membership of 34 seats: 24 were appointed by the Council of Chiefs, nine by the President and one by the Council of Rotuma. The Council of Chiefs also received the power to appoint the President and the two Vice-Presidents, giving them control over all institutions of government.

Table 4: 1990 Constitution distribution of electoral seats amongst Fiji's ethnic communities

\begin{tabular}{|l|c|c|c|c|}
\hline \multicolumn{1}{|c|}{ Ethnic Group } & Seats & Total Populations & \% of Total Population & $\begin{array}{c}\text { People Per } \\
\text { Seat }\end{array}$ \\
\hline Pacific-Fijian & 37 & 329,305 & 46.0 & 8,900 \\
\hline Indo-Fijian & 27 & 348,704 & 48.8 & 12,915 \\
\hline Rotuman & 1 & 8,652 & 1.2 & 8,652 \\
\hline Others & 5 & 28,714 & 4.0 & 5,743 \\
\hline
\end{tabular}

Source: Fiji 1990 Constitution.

The 1990 Constitution also explicitly stated that the office of Prime Minister must be filled by a Pacific-Fijian. As well as granting the Council of Chiefs the right to appoint two-thirds of the seats in the Senate, it granted it the right to appoint the President and Vice-President

308 Yash Ghai and Jill Cottrel, "A Tale of Three Constitutions: Ethnicity and Politics in Fiji," I•CON 5, no. 4 (2007): p. 640.

${ }^{309}$ Constitution of the Sovereign Democratic Republic of Fiji 1990.

${ }^{310}$ In the absence of credible statistics on registered voters from all of Fiji's ethnic communities I have used the total population statistics from the 1986 Census. 
as well. Finally, as Table 4 demonstrates, the constitution reserved a disproportionate number of electorate seats for Pacific-Fijians in the House of Representatives with PacificFijian constituent seats representing 8,9000 people and Indo-Fijian constituent seats almost 12,915 people. Seat allocation plainly ignored the demographic realities of the 1986 Census, which had counted a relatively even number of Pacific-Fijians and Indo-Fijians. Furthermore, the electoral reform also gerrymandered constituencies to favour rural provinces (see Table 5).

Table 5: 1990 Constitution distribution of Pacific-Fijian communal seats amongst regional provinces

\begin{tabular}{|c|c|c|c|c|}
\hline Area & Seats & Registered Voters & $\begin{array}{c}\text { \% of Total } \\
\text { Voters }\end{array}$ & Voters Per Seat \\
\hline $\begin{array}{c}\text { Rural Provinces } \\
\text { (14) }\end{array}$ & 32 & 110,619 & 65 & 3,457 \\
\hline $\begin{array}{c}\text { Urban Provinces } \\
\text { (5) }\end{array}$ & 5 & 43,276 & 35 & 8,655 \\
\hline
\end{tabular}

Source: Fiji 1990 Constitution.

The uneven distribution of Pacific-Fijian electorates under the 1990 constitutional reform discriminated against urban Pacific-Fijians whose loyalties to chiefly elites and conservative political positions were weaker than rural Pacific-Fijians, and which had bolstered the Labour Party's vote in the 1987 election. With these new electoral advantages, a chieflysponsored party that maintained unity within the Pacific-Fijian community should have been able to build a parliamentary majority government without the need for coalition. When the country returned to electoral governance in 1992, despite the protections of the new electoral system, exclusive chiefly control did not result, as conflict amongst chiefs had started to emerge.

Soon after independence Fiji seemed to be an example of a multicultural democracy for the post-colonial world, but, its democracy was very quickly proven a façade, as the power structures underlying its electoral institutions were exposed. If Cakobau's response to the constitutional crisis seemed merely benign and convenient in returning government to the control of the chiefs, Rabuka's 1987 coup confirmed the chiefs desire to bypass the electoral system to ensure their dominance of government. This overthrow openly displayed for the first time the chiefly elites control of a parallel set of authoritarian

311 These rural provinces coincide with the 14 traditional provinces of Fiji.

312 The urban provinces outlined were new constructions around the five main urban centres. 
institutions, which enabled them to usurp elected government. The following chapter examines the problems the chiefly elite encountered in elusively controlling government in Fiji, despite their constitutional advantages over electoral institutions. The political events of the 1990s brought the emergence of rifts within the chiefly elite. This exposed their previous as existing solely for material benefit. This in turn created a wide fracturing of this elite the conditions that would lead to the Labour Party's second electoral victory. 


\section{Chapter Five: Divided Authoritarianism 1990-2005}

In December 1987, following the September coup, Rabuka handed control of government to a selected group of political elites, predominantly high chiefs. This interim government then set about rewriting the 1970 Constitution, with their reforms targeting the electoral system and composition of Parliament. Provisions were built into the new constitution that created advantages for rural Pacific-Fijian political elites, aimed at skewing electoral results in order to benefit chiefly elites. However, this electoral engineering did not provide a longlasting monopoly on governance for chiefs. Rather, the post-coup civilian government and the new electoral system produced a fracturing of the chiefs' coalition and with it the Pacific-Fijian vote, opening up new political cleavages within Pacific-Fijian communities.

In this new political environment, the legitimacy of the 1990 Constitution soon disintegrated. Tensions between chiefs fractured the Pacific-Fijian vote, forcing Rabuka's SVT Party to call upon Indo-Fijian political support in the formation of coalition governments. This new political reality undermined the key aim of the 1990 Constitution: keeping government from Indo-Fijians. The 1997 constitutional reform ushered in a more proportionate distribution of electorate seats, bringing a sense of contestability back to Fiji's electoral system. These new electoral conditions enabled the Labour Party to capitalise on factionalism within the Pacific-Fijian community, and its newfound unity within Indo-Fijian community resulted in its landslide victory, taking power form the chiefly elite again at the 1999 general election. This second Labour Party victory presented a challenge to the chiefly elite similar to the election result of 1987 . This time, however, the chiefs lacked unity and this complicated their response.

This chapter explains the transition back to electoral governance in 1992 and the success of the two constitutions in providing electoral outcomes that seemed sustainable. First, it details the unravelling of the 1990 Constitution, the factionalisation of Pacific-Fijian political elites, and their power sharing with Indo-Fijian political parties. Second, it addresses the chiefs' reaction to their loss of government for a second time. 


\section{The decline of Pacific-Fijian chiefly unity 1990-1999}

Through the 1990s, Pacific-Fijian support for Rabuka deteriorated in concert with the perceived legitimacy of the 1990 Constitution. Although the Indo-Fijian proportion of the total population had decreased significantly following the events of 1987, the Labour Party was still able to win a majority of seats at the 1999 election. Just as in 1987 though, neither the Labour Party's margin of victory, nor its constitutional legitimacy, prevented the chiefs from ousting it, a year after its swearing in.

This section has two parts. First, it describes the return to civilian rule and constitutional elections, the subsequent decline of Rabuka's control over the country, and the political pressures leading to another constitutional reform and the 1997 Constitution. Second, it explains the Labour Party's victory at the 1999 general election and the tensions this nonchiefly-backed government created.

\section{Return to electoral rule}

Under international pressure, Fiji returned to electoral governance in May 1992, albeit according to a new constitution put in place by precisely those elites who had overthrown the previous government. ${ }^{313}$ After Rabuka handed control of the government to Ganilau as President and Mara as interim Prime Minister, he repackaged himself as a politician and the new guardian of Pacific-Fijian chiefly interest. Rabuka's SVT 'land-owners' Party served one purpose: maintaining the paramountcy of chiefly interest. ${ }^{314}$ Soon after this return to electoral governance, pressure built from the international community, the Indo-Fijian community, and sections of the Pacific-Fijian community to review the 1990 Constitution. The Labour Party made a constitutional review a key condition of their coalition agreement with the SVT in 1992. This review finally took place in 1996, ${ }^{315}$ but only after Rabuka faced mounting political pressure to do so from his coalition partner, National

\footnotetext{
313 Fiji was expelled from the Commonwealth of Nations and was also subject to international censure and numerous boycotts.

314 The Soqosoqo ni Vakavulewa ni Taukei Party (SVT) became commonly known as the 'landowners party', however, its literal translation is "The Association for Policy-Making by Fijians." Simione Durutalo and Epeli Hau'ofa, "Tonga's Pro-Democracy Movement: An Interview between Simione Durutalo and Professor Epeli Hau'ofa," Review 20 (1993).

315 Paul Reeves, Tomasi Rayalu Vakatora, and Brij V. Lal, "The Fiji Islands : Towards a United Future. Report of the Fiji Constitution Review Commission 1996," in Parliamentary Paper No. 34 of 1996, ed. Parliament of Fiji (Suva: Parliament of Fiji, 1996).
} 
Federation Party leader Jai Ram Reddy. This review's report produced the 1997 Constitution, which diluted the chiefs' influence over electoral processes and provided for fairer elections in 1999.

The 1990 Constitution's disproportionate distribution of electoral seats across ethnic communities, favouring Pacific-Fijians, along with the Council of Chiefs' explicit public support for Rabuka's SVT Party, should have guaranteed it an unassailable victory in the 1992 general election. Before this election, the chiefs had deemed that Mara's Alliance Party was a defunct political vehicle and the SVT, led by Rabuka, should succeed it. The Council of Chiefs openly endorsed the SVT, making it clear that this party would be now the standard bearer of chiefly interests. ${ }^{316}$ Yet, regardless of this backing, in both elections under the 1990 electoral system, the SVT only won a plurality of the votes and not the majority it needed to govern alone.

The electoral engineering of the 1990 reform proved to be flawed. Under the arrangements of the interim government, chiefs had governed without political challenge or electoral accountability. And before the 1987 coup, the chiefly elite had publicly maintained an appearance of unity in the face of the Indo-Fijian political threat. Yet, under interim arrangements, this threat dissipated and obvious factions quickly emerged. As high chiefs fought to control the levers of civilian government, political divisions between tribal hierarchies and between confederacies grew.

Disunity within the SVT nearly immobilised the party, further undermining the goals of the 1990 Constitution. It had attempted to create advantages that would ensure that a Pacific-Fijian government held office in perpetuity. ${ }^{317}$ These electoral advantages, however, had a detrimental effect on the unity of the Pacific-Fijian community. The apparent guarantee of an electoral majority permitted Pacific-Fijians to switch their focus to particular grievances amongst them, and this led to fracturing of their unity. Between 19921999, the SVT split into two factions. The main fissure inside the SVT was between Rabuka and Josevata Kamikamica and their respective supporters. Although Kamikamica was a commoner, he had been the Finance Minister in the interim government and was the previous General Manager of the NLTB, and therefore was held in high regard amongst

316 Something it had never provided a political party before. Even the Alliance had never received such an endorsement. Brij V. Lal, "Heartbreak Islands: Reflections on Fiji in Transition," Asia Pacific Viewpoint 44, no. 3 (2003): p. 338.

317 Lal, Islands of Turmoil: Elections and Politics in Fiji, p. 142. 
the high chiefs; he also had the personal backing of Mara and his close supporters. ${ }^{318}$ These factions refused to work together to form a government, yet neither of them was prepared to break away and form a separate party. Fortunately, for the chiefs, tight electoral competition amongst the Indo-Fijian parties and the limited number of Indo-Fijian seats restricted the Indo-Fijian political threat. Where constitutional reform had sought to engineer unchallenged Pacific-Fijian rule, factionalism within the Pacific-Fijian community made Indo-Fijian political support necessary in the formation of Pacific-Fijian-led governments.

In turn, the candidate selection process further exacerbated tensions between Pacific-Fijian factions. Provincial councils selected candidates, and their principal loyalty was to those who held provincial power. This meant that party leaders had limited influence over candidate selection, and even less when it came to disciplining them for failing to follow the party line. The predictable result was a proliferation of political parties, formed by disgruntled candidates touting regional interests and camouflaging private agendas under the guise of 'Pacific-Fijian interests'. ${ }^{319}$

Amongst this Pacific-Fijian factionalism, SVT ethno-nationalist MPs left the party to join either the Fijian Christian National Party or the Soqosoqo ni Taukei ni Vanua Party. These two parties formed a nationalist coalition as the Fijian National United Front (FNUF), which was led by Butadroka. The 1992 election also saw the emergence of the General Voters Party (GVP), representing the assorted 10,000 Europeans, part-Europeans, Chinese and other Pacific Islanders in Fiji. Meanwhile the dominant Indo-Fijian political vehicles remained. $^{320}$

At the 1992 election, the increase in new parties saw seats distributed across five political parties, see Table 6. The 37 Pacific-Fijian communal seats were split between the SVT, which won 30 of these, the FNUF which won five seats, with independent candidates winning the remaining two seats. The Indo-Fijian communal seats were split between the National Federation Party, with 14 seats, and the Labour Party, which won 13 seats, despite its decision to stand only weeks before the election. ${ }^{321}$ The GVP won the five general

\footnotetext{
318 Ralph Premdas, "General Rabuka and the Fijian Elections of 1992," Asian Survey 33, no. 10 (1993): p. 1001.

${ }^{319}$ Lal, Islands of Turmoil: Elections and Politics in Fiji, p. 236.

320 A large number of other political parties contested the 1992 election and won no seats.

321 Premdas, "General Rabuka and the Fijian Elections of 1992," p. 1007.
} 
seats. $^{322}$

Table 6: Fiji 1992 general election results

\begin{tabular}{|l|c|c|c|}
\hline \multicolumn{1}{|c|}{ Party } & $\begin{array}{c}\text { Pacific-Fijian Communal } \\
\text { Seats }\end{array}$ & $\begin{array}{c}\text { Indo-Fijian Communal } \\
\text { Seats }\end{array}$ & Other Seats \\
\hline SVT & 30 & - & - \\
\hline FNUF & 5 & - & - \\
\hline $\begin{array}{l}\text { National Federation } \\
\text { Party }\end{array}$ & - & 14 & - \\
\hline Fiji Labour Party & - & 13 & 5 \\
\hline GVP & - & - & - \\
\hline Independents & 2 & - & 5 \\
\hline & & & 27 \\
\hline
\end{tabular}

Source: Ralph Premdas, "General Rabuka and the Fijian Elections of 1992," Asian Survey 33, no. 10 (1993)

The SVT had won a majority of Pacific-Fijian communal seats, and a plurality of seats in Parliament, but still needed to form a coalition government. The problems of coalition building were heightened by inter-SVT tensions, with relationships between the factions having deteriorated to the point of unworkability by the time of the election. Rabuka had the support of 20 SVT MPs, while Kamikamica had the support of $10 \mathrm{MPs} .{ }^{323}$ Each group spoke openly about forging a coalition with its preferred Indo-Fijian party.

Rabuka initially sought a coalition with Pacific-Fijian focused parties, but was unable to reconcile differences between the GVP and the FNUF. This forced him to turn to IndoFijian support. After lobbying and horse-trading, Rabuka emerged with a workable majority of votes, forming a coalition with the GVP, independent MPs, and, ironically, the Labour Party. ${ }^{324}$ In the coalition agreement the Labour Party leader, Mahendra Pal Chaudhry, demanded and received a review of the 1990 Constitution, but requested no Cabinet seats. Nonetheless, the fact remained, that Rabuka had become Prime Minister with the support of the very party he had overthrown only five years earlier. Rabuka's need for Labour Party support further demonstrated the extent of disunity within the Pacific-Fijian community after the 1987 coup. This created divisions amongst the highest chiefs and foreshadowed the political ruptures that later emerged.

\footnotetext{
322 Ibid.: p. 1006.

${ }^{323}$ At the SVT's party convention Rabuka only beat Kaikamica in the leadership ballot by only one vote. Ibid.: p. 1001.

324 Ibid.: p. 1008.
} 
Table 7: Fiji 1994 general election results

\begin{tabular}{|c|c|c|c|}
\hline Party & $\begin{array}{l}\text { Pacific-Fijian Communal } \\
\text { Seats }\end{array}$ & $\begin{array}{l}\text { Indo-Fïian Communal } \\
\text { Seats }\end{array}$ & $\begin{array}{l}\text { Other } \\
\text { Seats }\end{array}$ \\
\hline SVT & 32 & - & - \\
\hline FNUF & 5 & - & - \\
\hline National Federation Party & - & 20 & - \\
\hline Fiji Labour Party & - & 7 & \\
\hline GVP & - & - & 4 \\
\hline Independents & 1 & - & - \\
\hline Total & 37 & 27 & 5 \\
\hline
\end{tabular}

Source: Brij V. Lal, Islands of Turmoil: Elections and Politics in Fiji (Canberra: Asia Pacific Press 2006)

Rabuka's government lasted only 18 months when, as the Labour Party abandoned the coalition after Rabuka failed to deliver the promised constitutional review. After Labour pulled its support, Rabuka's government was unable to pass a budget in November 1993, and the following general election in February 1994 produced a moderate redistribution of seats, see Table 7. The SVT again won a majority of Pacific-Fijian communal seats with 32, while the FNUF secured five seats. In the Indo-Fijian communal seats, the National Federation Party gained six seats from the Labour Party, while the GVP lost one general seat to an independent candidate who had left that party. Once again, Rabuka's SVT faction forged a coalition government, though this time with the GVP and the National Federation Party.

Under the 1990 Constitution, a Pacific-Fijian majority in the House of Assembly and the ethnicity of the Prime Minister were a foregone conclusion. The distribution of electoral seats and gerrymandering of electorates had guaranteed this. Although electoral processes determined the composition of the constituent seats, satisfying the demands of the international community, the electoral system was severely restricted in its capacity to determine the composition of government. Disregarding the structure of Fiji's political economy, with the constitutionally entrenched chiefly control over the economy, the international community naively viewed the return to electoral governance as the equivalent to a return of 'democracy'. ${ }^{325}$ The effective inability of Fiji's electoral processes to determine the composition of government through a contestable process, however, was further limited under the new electoral laws of 1990. Although this reform ensured each

325 Under each of Fiji's constitutions the provision providing the Council of Chiefs with veto over reform of the land tenure system and the unelected status of the Senate, restricts the status of Fiji's political institutions to only being electoral, not democratic. 
electoral result was predictable and unthreatening for the chiefs, the conditions it produced paradoxically worked to undermine the intentions of the 1990 constitutional reform.

\section{Another constitution}

Through the 1990s, the legitimacy of the 1990 Constitution and its imbalanced electoral terms faded, and support for constitutional reform grew. In 1995, under pressure from the National Federation Party, Rabuka finally agreed to appoint a commission to review the constitution. This three-person commission's brief directed it to reform Fiji's political institutions and promote cross-ethnic sharing of executive power, in order to neutralise ethnic antagonism as a tool of political mobilisation.

The Reeves Commission delivered its report to the President, and a bipartisan Parliamentary Select Committee was established to consider its recommendations. Many conservative Pacific-Fijian MPs rejected the Commission's emphasis on national unity over communal affiliations and institutions. They also dismissed the Commission's comparison of Fiji to other jurisdictions as a gauge of Fiji's constitutional provisions. Instead, they claimed that Fiji was a unique country and its Pacific-Fijian peoples had unique rights and needs. ${ }^{326}$ After diluting the Reeves Commission's recommendations, particularly concerning the proportions of open and communal seats, the Select Committee passed a draft constitution to the President, who then ratified it and the new constitution was subsequently passed into law.

The key reform of the 1997 Constitution was the return to an ethnic and geographically proportionate distribution of electoral seats. ${ }^{327}$ In the 1997 Constitution, the lower house of the legislature, formerly the House of Assembly, was renamed the 'House of Representatives', and its membership increased by one seat. Out of its 71 seats, 25 were general constituencies elected by all Fijians, with the remaining 46 retained as communal constituencies, divided proportionally amongst Fiji's ethnic communities. Twenty-three of these were reserved as Pacific-Fijian communal seats, 19 as Indo-Fijian seats, three for

326 Lal, Islands of Turmoil: Elections and Politics in Fiji, p. 132.

327 Although, the redistribution of seats amongst ethnic communities was more propionate than that of the 1990 Constitution, it was not totally proportionate. Notably, Pacific-Fijian electorates still skewed with rural constituencies having fewer voters per seat than urban constituencies. 
'other' ethnic groups, and one for Rotumans. ${ }^{328}$ Along with this, the first-past-the-post electoral system was replaced with the alternative vote system, where voters ranked candidates in order of preference. The reform also included new provisions aimed at encouraging the formation of multi-party, cross-ethnic governments. ${ }^{329}$ Notably, however, the parliamentary select committee rejected the Reeves Commission's proposal to open the appointment of the Senate up to the popular vote. Instead, it preserved the existing appointment processes and retained the constitutional provisions that provided the Council of Chiefs veto power over reform of the land-tenure system. While, these constitutional changes liberalised the electoral system, they still did not remove the legislative veto of the Senators nominated by the Council of Chiefs, and therefore failed to democratise Fiji's electoral institutions decision-making abilities.

Although the 1997 Constitution brought some contestability back to Fiji's electoral process, it did not remove the dominance of the chiefly elite within Fiji's political institutions. By providing seats proportionate to Fiji's ethnic communities, and with constitutional provisions encouraging cross-ethnic, multi-party coalition governments, the chiefs aimed to only provide a limited, but sustainable model, of electoral governance.

\section{A new challenge authoritarianism}

The splintering of the Pacific-Fijian vote and the Labour Party's success in 1999 shocked both political observers and the chiefs. The Labour Party capitalised on the National Federation Party's close relationship with Rabuka, which had grown very unpopular, and swept both the Indo-Fijian communal electorates and the general electorates. This success represented a major challenge to the chiefly elite with an Indo-Fijian occupying the office of Prime Minister for the first time. This resurgence of the electoral process, however, did not last long. Once again, as chiefs lost electoral control, they overthrew the elected government.

For the 1999 general election, political parties campaigned in broad blocs to project probable coalition partners and, therefore, the likely composition of government. The

328 Rotumans are from the island Rotuma, which is north west of Fiji's northern Mamanuka islands. Constitution of the Republic of the Fiji Islands 1997. Section 51., (a), i-iv

${ }^{329}$ There is a clause obligating the party with the largest votes to approach the party with the second largest vote to form a coalition. Ibid. 
parties of the incumbent government: the SVT, National Federation Party and United General Party, campaigned with draft coalition agreements ready to implement after the election. To present an alternative to Rabuka's government, the Labour Party affiliated itself with potential coalition partners, forming the People's Coalition between itself, the Party of National Unity (PANU) and the Fijian Association Party. Notably it was key members of Kamikamica's SVT faction who formed the Fijian Association Party, which supported Chaudhry in his formation of a government. In turn, a third coalition, between Pacific-Fijian parties opposed to Rabuka's policies and the concessions the 1997 Constitution had granted to Indo-Fijians, was launched on the eve of the election. This coalition comprised the Veitokani ni Lewenivanua Vakaristro Party and the Christian Democratic Alliance.

At the 1999 election Rabuka's coalition government a suffered massive defeat, and particularly the SVT's vote was splintered among the several parties that contested the Pacific-Fijian communal seats, see 8. Among the parties of the People's Coalition, the Labour Party won an outright majority of 37 seats, including all 19 Indo-Fijian communal seats, and 18 of the 25 open seats. The Fijian Association Party won 11 seats, and the PANU won four seats. Of the incumbent coalition's parties the SVT won eight seats, the United General Party won two seats, and the National Federation Party won no seats Minor parties and independent candidates won the remaining seats, see Table 8. Although Chaudhry won enough seats to govern alone, he proceeded with the formation of a government of the People's Coalition, as encouraged by new constitution. ${ }^{330}$

Table 8: Fiji 1999 general election results

\begin{tabular}{|l|c|c|c|c|c|c|}
\hline \multicolumn{1}{|c|}{ Party } & $\begin{array}{c}\text { Pacific-Fijian } \\
\text { Communal } \\
\text { Seats }\end{array}$ & $\begin{array}{c}\text { Indo-Fijian } \\
\text { Communal } \\
\text { Seats }\end{array}$ & $\begin{array}{c}\text { Council } \\
\text { of } \\
\text { Rotuma }\end{array}$ & $\begin{array}{c}\text { Other } \\
\text { Seats }\end{array}$ & $\begin{array}{c}\text { General } \\
\text { Seats }\end{array}$ & Total \\
\hline Fiji Labour Party & - & 19 & - & - & 18 & 37 \\
\hline SVT & 5 & - & - & - & 3 & 8 \\
\hline Fijian Association Party & 9 & - & - & - & 2 & 11 \\
\hline United General Party & - & - & - & 1 & 1 & 2 \\
\hline PANU & 4 & - & - & - & - & 4 \\
\hline Christian Democrats & 2 & - & - & - & - & 2 \\
\hline Fiji Nationalist Party & 1 & & - & 1 & & 2 \\
\hline Independents & 1 & - & 1 & 1 & 2 & 5 \\
\hline \multicolumn{1}{r|}{ Total } & 23 & 19 & & & & \\
\hline
\end{tabular}

${ }^{330}$ Lal, Islands of Turmoil: Elections and Politics in Fiji, p. 173-78. 
Source: Brij V. Lal, Islands of Turmoil: Elections and Politics in Fiji (Canberra: Asia Pacific Press 2006)

Before the new parliament met for its first session, Rabuka abruptly resigned to take up a position as chair of the Council of Chiefs. His tenure as Fiji's dominant political actor had been brought to an end by the electoral process and by the party that he had overthrown in 1987. Rabuka won the chairmanship of the Council under a secret ballot with 32 votes to Tui Vuda Ratu Josefa Iloilo's 18. Notably, at his victory Rabuka announced it to be "a sign of the chiefly support I have", not to mention a product of his role in deposing the elected government in 1987 and supporting chiefly agendas as Prime Minister throughout the 1990 s. $^{331}$

The close political relations between the National Federation Party and Rabuka's SVT faction had clearly undermined the National Federation's credibility in Indo-Fijian communities. Specifically, many perceived that the National Federation Party's leader Jai Ram Reddy was too close to Rabuka, whom many Indo-Fijians still resented for his role in the 1987 coup. Reddy had even addressed the Council of Chiefs, requesting their blessing for the proposed constitutional reform. At the same time, although the Labour Party had also supported Rabuka's government in 1992, it subsequently brought that government down by withholding its votes for the government's budget in November 1993. This initially undermined the Labour Party's electoral appeal in the short-term, but in the longterm reinforced its credibility as an independent political force and advocate for both IndoFijians and non-chiefly aligned Pacific-Fijians.

Unsurprisingly, many chiefs found it difficult to tolerate an Indo-Fijian Prime Minister and the Labour Party's dominance in government. The efforts of the first coup to keep government out of Indo-Fijian hands had obviously failed, with Indo-Fijians constituting part of every coalition since 1992, and now in 1997 controlling the government outright.

Furthermore, the positive effect of the Council of Chiefs' sponsorship of the SVT had faded through the 1990s, with chiefly factions splintering and Indo-Fijians maintaining influence in government. Under the new electoral system, Chaudhry had not only unified Indo-Fijians but also attracted high levels of support in the open seats. His electoral mandate, partnered with his decision to include many Pacific-Fijians in his cabinet, put chiefs in a difficult position. The chiefs could not claim outright that Pacific-Fijian interests

331 Ibid., p. 187. 
were not represented in government, but these were also not their own specific PacificFijian interests but those of the middle-class and commoners. As time progressed, these tensions grew, and presented a paradox for the chiefly elite. Despite the majority of chiefly being were sidelined from government, many 'moderate' chiefs saw little room for action and made it clear they did not want a repeat of the turmoil that had crippled Fiji for the previous decade. Nevertheless, after prolonged agitation, action did occur and was orchestrated by conservative chiefs.

\section{The reassertion of Pacific-Fijian nationalism 2000-2005}

The 2000 putsch $^{332}$ demonstrated the entrenched dominance of the Pacific-Fijian chiefs and their intolerance of the elected government. After a slow transition back to civilian government and then democratic elections, the constitutional reform in 1997 was thought to have provided Fiji with sustainable electoral institutions. The focus of these reforms, however, ignored the underlying realities of Fiji's political economy and did nothing to alter the power structure in Fijian society. Consequently, when elections delivered an undesirable outcome, a group of chiefs responded in a similar manner to those in 1987, albeit without the chiefly unity of that first coup. Using extra-constitutional means this subset of the chiefs ousted the Labour-led government in May 2000, and ensured that it was not reinstated in the subsequent transition back to civilian rule.

This section has two parts. First, it explains the putsch that overthrew the Labour-led government. Second, it describes the political aftermath of the civilian putsch, and the marginalisation of the deposed Labour-led government in the transfer back to constitutional and civilian rule.

\section{The civilian putsch}

Despite the return to elected government in 1992, and the partial liberalisation of the electoral system in 1997, Fiji's constitutional and electoral institutions were once again

\footnotetext{
332 I use putsch to distinguish the coups of 1987 and 2006, which were led by high military personal, with the
} 2000 overthrow which was led by civilians with the support of private military personal. 
usurped. Elections under the 1990 electoral laws produced two successive governments led by Rabuka's SVT Party with coalition support from non-chiefly backed parties. While Indo-Fijian political support had been crucial to the formation of government, they exerted little influence on policy outcomes, with the exception the constitutional reform. Despite the increased factionalism between chiefly elites from 1992 to 1999, chiefs still maintained overall control of government, with the assistance of the electoral advantages provided to Pacific-Fijians by the constitution.

The chiefs' response to an Indo-Fijian government in 1999 differed to that of 1987. In 1987, the chiefs had responded to an Indo-Fijian majority in Cabinet with unanimous support for the military's overthrow of the government. In 1999, however, this unity was absent. Division among chiefs complicated the Pacific-Fijian response to an Indo-Fijian Prime Minister and accordingly, there was no swift action to topple Chaudhry. Rather, the movement for change mounted slowly as the persistence of an Indo-Fijian controlled government increasingly threatened chiefly authority. The eventual ousting of the People government came from a different source to that in 1987.

On 19 May 2000, an armed paramilitary stormed the parliamentary buildings, taking members of the government hostage. The group was partly comprised of members of the Republic of Fiji Military Force's (RFMF) Counter Revolutionary Warfare Unit (CRWU). This armed group was led by the CRWU's Commander, Major Iliisoni Ligari, and civilian George Speight. ${ }^{333}$ Although enacted by a military unit, this was essentially a putsch by a group of armed civilians. ${ }^{334}$ This was made clear by their first words as they stormed the House of Representatives, they announcing it was a civilian coup by the taukei $i^{335}$ people. ${ }^{336}$

The timing of the putsch was not accidental. 19 May 2000 was the Labour-led government's first anniversary in office, and it was the day the government was to present the Social Justice Bill. This bill was designed to spread government assistance to the most disadvantaged communities in Fiji. However, many Pacific-Fijian political elites interpreted

\footnotetext{
333 Speight, who emerged as the putsch's leader, was until then largely unknown, except for allegations of fraudulent business against him. Notably George Speight did have a close association with parliamentary politics because his father Sam Speight (Savenaca Tokainavo) was an SVT Party MP. Christene Gounder, "Journalists and the George Speight Coup," Pacific Journalism Review 13, no. 1 (2007): p. 125.

334 Roderic Alley, "Fiji's Coups of 1987 and 2000: A Comparison," Revue Juridique Polynesienne 1 (2001): p. 218.

335 Taukei is Pacific-Fijian for Pacific-Fijian people.

336 Brij V. Lal, "'Chiefs and Thieves and Other People Besides': The Making of George Speight's Coup," The Journal of Pacific History 35, no. 3 (2000).
} 
it as dismantling the pro-Pacific-Fijian affirmative action policies established after the 1987 coup. In response, the Taukei Movement, resurgent as a challenge to the non-chiefly backed government, planned a protest. Some 15,000 Pacific-Fijians marched through the streets of Suva, and the protest soon broke down into a riot and shops were looted. One this day 269 people were arrested in the disturbance, which caused F\$ 30 million in damages. ${ }^{337}$ All of this took place on a day when the Police Commissioner happened to be on holiday, the President (Mara) was in Lau celebrating his $80^{\text {th }}$ birthday, and the Head of the RFMF, Commodore Voreqe Frank Bainimarama, was visiting Fijian peacekeeping troops in Lebanon. ${ }^{338}$

With Bainimarama absent, Speight and his group hoped the RFMF would back the uprising. Instead, the military encircled the parliamentary complex, commencing a protracted siege. The RFMF, however, went no further; claiming further interference with Speight's actions would endanger the hostages. ${ }^{339}$ This led some commentators to suggest that the army's failure to secure the parliament, deny Speight access to the news media, and prevent his people from looting Suva and the farms beyond, all point to the military's complicity in the hostage taking. ${ }^{340}$ Nationalist leaning chiefs, whose identities and roles were later revealed in a swath of court cases and convictions, had in fact neatly orchestrated the events of the day behind the scenes.

It became clear soon after 19 May that while the putsch had not been undertaken by the RFMF or fronted by the highest of Fiji's chiefs, it had the support of many important chiefs. Rabuka publicly conceded his complicity in preparing the putsch and he disclosed that, as with Mara before the 1987 coup, he had played golf with Speight shortly before the overthrow, and that the CRWU forces that led the putsch had trained on his estates shortly before it took place. ${ }^{341}$ Rabuka also publicly expressed his support for the goals of Speight's putsch. Notably, former Senator Laisenia Qarase also voiced public support for Speight's goals and was later installed as Fiji's interim Prime Minister. Pacific-Fijian parliamentarians quickly fell in behind Speight's putsch, with a large number of former

337 "F\$" indicates Fijian Dollars

Mosmi Bhim, "The Impact of the Reconciliation, Tolerance and Unity Bill on the 2006 Election," in From Election to Coup: The 2006 Campaign and Its Aftermath, ed. Jon Fraenkel and Stewart Firth (Canberra: Asia Pacific Press, 2007), p. 115.

${ }^{338}$ Lal, "'Chiefs and Thieves and Other People Besides': The Making of George Speight's Coup," p. 288.

339 Bhim, "The Impact of the Reconciliation, Tolerance and Unity Bill on the 2006 Election," p. 115.

340 Alley, "Fiji's Coups of 1987 and 2000: A Comparison," p. 223.

341 Jon Fraenkel, "The Clash of Dynasties and Rise of Demagogues; Fiji's Tauri Vakaukauwa of May 2000," The Journal of Pacific History 35, no. 3 (2000): p. 296. 
SVT ministers in Rabuka's government appearing alongside Speight during the hostage crisis. ${ }^{342}$ In addition, nine of the 11 Fijian Association Party MPs proclaimed their support for Speight on the afternoon he took over Parliament, despite their coalition with the FLP. $^{343}$

In contrast with the 1987 coup, the chiefs' overthrow of the election of an Indo-Fijian government in 2000 was delayed by their own disunity. Mara, as President, had overseen the installation of the Labour-led government, and in doing so provided it legitimacy. This act had compromised Mara and his supporters in the eyes of hardliners. Speight represented a new generation of Pacific-Fijians who were brought up after the 1987 coup, and under the conditions of the 1990 Constitution. They had experienced a Fiji dominated by Pacific-Fijian political leadership, although this leadership was not united under a single high chief as it had been before 1987. ${ }^{344}$ Mara's support for the Labour-led government troubled many Pacific-Fijian chiefs who demanded that action be taken to reinstate chiefly control of government. Speight's actions, and those of the chiefs who backed him, were as much a challenge to Mara's chiefly authority as they were to the toleration of an IndoFijian government. ${ }^{345}$

The putsch threw Fiji's constitutional institutions into disarray. The day after the invasion of Parliament, high chief Ratu Jope Seniloli, usurping the role of the President, swore Speight in as the new Prime Minister of Fiji, and his accomplices as Fiji's cabinet. Under the 1997 Constitution, the Council of Chiefs had the sole right to appoint the President, and on 23 May it met in response to Senioli's actions, to determine the legal status of Mara's power. During the meeting, Rabuka pronounced "Democracy, as we have always stated, [is] a foreign flower ${ }^{346 \text { ", }}$, and he demanded that it should be refined to meet the needs of local circumstances. Although many high chiefs agreed with Rabuka, and sympathised with Speight's cause, the Council as an institution backed Mara to lead the country out of crisis. ${ }^{347}$ Importantly, in affirming Mara as President, the Council rejected Senioli's appointments and his self-claimed authority to make such appointments.

\footnotetext{
342 Ibid.: p. 297.

343 Ibid.: p. 298.

${ }^{344}$ Speight was an odd leader for the civilian putsch. He did not present himself as a traditional Pacific-Fijian, using his European name, and speaking to journalists exclusively in English.

345 Teresia Teaiwa, "An Analysis of the Political Crisis in Fiji," Scoop Media, 23 May 2000.

346 This same phrase was used by the political Taukei movement after the 1987 election. Lal, "Rhetoric and Reality: The Dilemmas of Contemporary Fijian Politics," p. 97.

${ }^{347}$ Bhim, "The Impact of the Reconciliation, Tolerance and Unity Bill on the 2006 Election," p. 115.
} 
Mara quickly attempted to defuse the crisis. He sought to transfer the constitutional powers of the office holders who were being held hostage inside the parliamentary complex to another cabinet member, outside. He appointed Ratu Tevita Momoedonu ${ }^{348}$ as Prime Minister. As civil order deteriorated however, Bainimarama, who had returned to Fiji, informed the President that he believed the 1997 Constitution was no longer a suitable framework within which to resolve the crisis. Mara heeded this demand by abrogating the constitution, stepping aside as President, and formally dismissing the Labour-led government. This move then allowed the military to take over, with the second Labour-led government dismissed in a manner reminiscent of $1987 .^{349}$

Three weeks after the putsch, NLTB General Manager Maika Qarikau and Conservative Alliance MP Niko Nawaikula circulated a 20-page 'Deed of Sovereignty' document, which demanded the return of all state and freehold land to Pacific-Fijian ownership, and its conversion into native land. ${ }^{350}$ This 'Deed of Sovereignty' was modelled on the 1874 Deed of Cession and sought to significantly alter Fiji's land-tenure system. ${ }^{351}$ Although the Deed claimed it transferred this land to Speight's government, its legal status was dismissed by subsequent constitutional rulings by the Court of Appeal. Nonetheless, the Deed and its proponents indicate further underlying motivations for the putsch, to permanently shift the political-economic balance of Fiji towards chiefly interests and place political control beyond the reach of any electoral system.

The crisis ended when Speight and Bainimarama signed the Muanikau Accord on 9 July 2000. Speight held the hostages for 56 days, before releasing them on 13 July 2000. The Muanikau Accord promised Speight and his accomplices immunity from criminal prosecution and civil liability in exchange for freeing the hostages and surrendering their weapons. Soon after the release of hostages, however, Bainimarama claimed Speight had not properly surrendered, having found him in possession of more weapons, and arrested him and other key players of the putsch, charging them with treason.

Although the Council of Chiefs had stymied Speight's attempts to replace the ousted government with his own cabinet, the putsch had still been successful for the protagonists.

348 Momoedonu had not been present at Parliament during the putsch.

349 Alley, "Fiji's Coups of 1987 and 2000: A Comparison," p. 223.

${ }^{350} \mathrm{Lal}$, "'Chiefs and Thieves and Other People Besides': The Making of George Speight's Coup," p. 287.

351 Robertson and Sutherland, Government by the Gun: The Unfinished Business of Fiji's 2000 Coup, p. 28. 
In this constitutional vacuum, Bainimarama appointed an interim civilian government, replacing the Labour-led government, with former Senator Qarase as Prime Minister. ${ }^{352}$ The interim government also included former SVT MPs from Rabuka's faction. While the appointment of an interim government quelled tensions, it also installed as ministers several nationalist chiefs who had orchestrated the putsch. Legal prosecutions would later reveal the significance of these associations. Speight's ultimate goal was not to govern Fiji, but rather to prevent a non-chiefly-backed party from doing so. In this sense, the putsch viewed as a success.

The events surrounding the 2000 putsch not only displayed, but also exacerbated, factionalism among chiefs, which had burn to emerge in the early 1990s. These factions emerged across both eastern and western tribal confederacies, but also within each confederacy. Speight framed his putsch as a rising of his eastern Kubuna confederacy against the western Tovata confederacy. In doing this, he targeted Mara personally, demanding his resignation from the Presidency. As well as installing a Labour-led government, Mara was accused of using his political dominance to extend his family's control of the paramount chiefly titles. ${ }^{353}$

The intra-confederacy conflict between chiefs was over how to react to Speight's putsch, and how much public support they should lend it. Many chiefs had historical and family ties crossing confederacies and this, combined with sub-confederate tribal units, complicated traditional alliances. The third confederacy, Burebasaga, had become closely involved with the putsch, but its highest chiefs were also closely aligned with Mara, whose wife held its highest chiefly title. Intra-confederacy loyalties were in tatters as a proliferation of national political factions though the 1990s and the events of the 2000 putsch undermined traditional chiefly alliances. A month after the putsch an army spokesman reflected on the rifts that had appeared, saying they "are riddled with personal agendas" and that the chiefs were incapable of impartial and decisive action. ${ }^{354}$ This was undoubtedly a product of the new political conditions created after the 1987 coup.

\footnotetext{
352 Although Qarase was not a high chief, he had previously held an influential position in the Fijian economy, as the Managing Director of the Fiji Development Bank.

353 There are three paramount chiefly titles in Fiji. They are the highest chiefly rank within the Pacific-Fijian chiefly system.

${ }^{354}$ Lal, "'Chiefs and Thieves and Other People Besides': The Making of George Speight's Coup," p. 282.
} 
The non-renewal of the ALTA lease agreements

From 1997, the thirty-year ALTA lease agreements, which had been first signed as ALTO agreements in 1976, began to expire. This raised the politically sensitive issue of the structure of Fiji's land-tenure system. As these lease agreements expired, some landowners were unwilling to extend their terms, choosing instead to cultivate the land themselves, or to apply to have the land re-zoned as non-agricultural, permitting it to be leased under the more favourable NLTA terms. Others threatened to pursue such actions, as a means to extract higher rents from tenants. By the end of 2009, 4521 (91\%) of the ALTA leases will have expired. Of the ALTA leases, 93.7\% have been held by Indo-Fijians (see Appendix 2 for the annual expiry of ALTA sugarcane leases held by Indo-Fijians), yet between 1997 and 2002 , only $48 \%$ of the expired lease agreements were renewed to existing tenants. ${ }^{355}$ Where previously renewal of native land lease agreements, had been relatively easy to attain, given the right lease terms, with the expiry of the ALTA agreements, many land owners simply rejected any renewal under them. This action further reflects the extent to which the land-tenure system has been politicised in Fiji dating back to Mara's decision to formalise the ALTO in 1976.

The NLTB, which campaigned against the formalisation of the ALTA in 1976, led a campaign against the renewal of the ALTA lease agreements from 1997, seeking the extension of NLTA to cover agricultural leases. ${ }^{356}$ A 1997 NLTB survey suggested that many native land owners either wanted to reclaim their lands or alter leasing terms and rents rates. The NLTB argued that the valuation system of Unimproved Capital Value (UCV) was severely undervaluing land and that $6 \%$ was too low a percentage of UCV to pay for a lease rent. ${ }^{357}$ As NLTB General Manager from 1998 to 2002 Qarikau personally campaigned against native land owners extending the ALTA leases by rallying at provincial councils and through his networks in the Methodist Church. ${ }^{358}$

Where the NLTB's actions may have seemed counterintuitive, given they eroded land owners' rental revenue earnings, ${ }^{359}$ they served a deeper purpose. Although landowners lost

\footnotetext{
355 Biman C. Prasad and Paresh Kumar Narayan, "Fiji Sugar Corporation's Profitability and Sugar Cane Production: An Econometric Investigation, 1972-2000," in USPEC Working Paper (Suva: USPEC, Department of Economics, University of the South Pacific, 2003), p. 14.

356 Maika Qarikau, 'The General Manager's Report', Native Land Trust Board, "Native Land Trust Board Annual Report 1999," p. 7.

${ }^{357}$ Laisenia Qarase whilst Prime Minister (2001-2006) also argued the ALTA terms are unfair to landowners.

${ }^{358}$ Lal, "'Chiefs and Thieves and Other People Besides': The Making of George Speight's Coup," p. 287.

359 The NLTB has cited the expiry of ALTA lease as having a significant impact on its rental incomes. 'The
} 
revenue by allowing expiring ALTA lease agreements to go unrenewed, this non-renewal strategy altered and continues to alter, the demographic composition of rural Fiji. All IndoFijian ALTA lease agreements serve a dual purpose, because the agricultural leases also provide their tenants with residences. Tenants whose ALTA leases are not extended therefore face eviction from the land they have resided on for at least thirty years, and which families have often held for generations. Being unable to attain leases in rural areas evicted tenants are forced to urban areas, particularly the slums in Fiji's main urban centres. Rabuka has played an important role in the ALTA debate as chair of the Council of Chiefs. His assertion on the matter is indicative of the chiefs' strategy behind the non-renewal policy:

"In the next five to ten years there will be significant change. The majority of the leases will expire and return to the Fijian communities. And then there may be a decline in the value of land. It may not be as attractive as when it was openly available, which the Fijians will have to adapt themselves to, and look at ways and means to get the maximum value out of their land...My other hope is that the Indians will migrate. We tighten the controls, then Fiji is no longer attractive to the Indian settler as it has been over the last 120 years. Maybe they will slow down their immigration rate, thereby having a natural decline in their numbers, to a level about would be manageable [sic]." 360

Consistent with conservative chiefly sentiment, interim Prime Minister Qarase used populist claims to support the NLTB's strategy for the non-renewal of ALTA leases. Qarase argued at the Commonwealth Ministerial Action Group in 2000, that the ALTA system was unfair to land owners because sugar farmers were not passing on the high profits apparently being made through the Sugar Protocol subsidy. ${ }^{361}$ Overall, the deliberate non-renewal policy of many chiefs, combined with the NLTB's efforts, and the SVT- and SDL-led government's campaign for non-renewal of ALTA leases, has served to accelerate Indo-Fijian emigration from Fiji, which had begun after the 1987 coup.

General Manager's Report, Native Land Trust Board, "Native Land Trust Board Annual Report 2003," p. 4.

360 Sharpham, Rabuka of Fiji: The Authorised Biography of Major-General Sitiveni Rabuka, p. 316.

${ }^{361}$ Lal, Lim-Applegate, and Reddy, "Alta or Nlta: What's in a Name? Land Tenure Dilemma and the Fiji Sugar Industry," p. 15. 


\section{The aftermath of the putsch}

The events of May 2000 demonstrated that the electoral changes of the 1997 Constitution had not altered the chiefs' position parallel to constitutional order. This authoritarian structure is entrenched in the constitution and permeates all facets of Fijian life. The events of 1987 and 2000 demonstrate that in Fiji, the maintenance of government and electoral institutions is contingent on the support of the chiefs. Even when internally divided, this authoritarian elite possessed the necessary political, institutional, social and material capacities to usurp elected government.

Although the 1997 Constitution lessened the electoral advantages granted to rural PacificFijian electorates, it failed to bring democratic decision-making to the institutions of power. The authoritarian structures undergirding Fiji's political economy continued to give the chiefly elite direct influence over Fiji's highest political institutions. These powers, on top of the social control that chiefs exerted over commoners and their economic privileges, negated the concessions of ethnically and geographic proportionate seat distribution in the 1997 Constitution.

On 1 March 2001, the Court of Appeal ruled the 2000 putsch unconstitutional and restored the 1997 Constitution as the supreme law of Fiji. ${ }^{362}$ Soon after the court's decision, interim Prime Minister Qarase announced that Fiji would return to democratic rule under the electoral laws of the 1997 Constitution. ${ }^{363}$

National elections were then held between 27 August and 1 September 2001. Two new Pacific-Fijian political parties, the SDL led by Qarase, and the Matanitu Vanua Party, were launched before the election. Both represented political elites supportive of Speight's putsch. Each sought to replace Rabuka's SVT Party as the dominant Pacific-Fijian party, and campaigned on an explicitly nationalist platform. In the post-putsch political environment, the SDL won a plurality of the vote, with 32 seats. The Labour Party was the second largest parliamentary party with 28 seats. The Conservative Alliance-Matanitu

\footnotetext{
362 Ghai and Cottrel, "A Tale of Three Constitutions: Ethnicity and Politics in Fiji," p. 665.; George Williams, "The Case That Stopped a Coup? The Rule of Law and Constitutionalism in Fiji," Oxford University Commonwealth Law Journal 73, no. 1 (2001): p. 2.

363 These events, centering upon the decision of the Court of Appeal, were an important landmark in the history of Fijian public law. It was the first time that the leaders of a coup voluntarily submitted to the jurisdiction of a court and came only months after a takeover. It is also the first time that a court decision restored a Constitution, and the electoral system created by it.
} 
Vanua Party (CAMV) won six seats. Minor parties won the remaining seats, see Table 9. Importantly the most conservative Pacific-Fijian party, the SDL, housing many key supporters and protagonists of the putsch, won out as the protector of Pacific-Fijian interests against the more moderate SVT and Fijian Association Party, which failed to win any seats. Together the SDL, CAMV and the New Labour Unity Party formed a coalition government.

Table 9: Fiji 2001 general election results

\begin{tabular}{|l|c|c|c|c|c|c|}
\hline \multicolumn{1}{|c|}{ Party } & $\begin{array}{c}\text { Pacific-Fijian } \\
\text { Communal } \\
\text { Seats }\end{array}$ & $\begin{array}{c}\text { Indo-Fijian } \\
\text { Communal } \\
\text { Seats }\end{array}$ & $\begin{array}{c}\text { Council } \\
\text { of } \\
\text { Rotuma }\end{array}$ & $\begin{array}{c}\text { Other } \\
\text { Seats }\end{array}$ & $\begin{array}{c}\text { General } \\
\text { Seats }\end{array}$ & Total \\
\hline SDL & 18 & - & - & 1 & 13 & 32 \\
\hline Fiji Labour Party & - & 19 & - & - & 9 & 28 \\
\hline CAMV & 5 & - & - & - & 1 & 6 \\
\hline $\begin{array}{l}\text { New Labour Unity } \\
\text { Party }\end{array}$ & - & - & - & 1 & 1 & 2 \\
\hline United General Party & - & - & & 1 & - & 1 \\
\hline Independents Total & 23 & - & 1 & - & 1 & 2 \\
\hline \multicolumn{1}{|r|}{} & & 19 & 1 & 3 & 25 & 71 \\
\hline
\end{tabular}

Source: Brij V. Lal, Islands of Turmoil: Elections and Politics in Fiji (Canberra: Asia Pacific Press 2006)

The SDL-led government, under Qarase, sought to consolidate its electoral base by rewarding the chiefly protagonists and supporters of the 2000 putsch. Notably, Seniloli, who had less than a year earlier sworn himself in as President during the putsch, was appointed Vice-President, even though he had been convicted for commissioning this unlawful oath. ${ }^{364}$ Despite this conviction he retained his title as Vice-President and full pay while in prison, and served only four months of his four-year sentence, after being released early by Qarase's government. ${ }^{365}$ Others such as Ratu Inoke Kubuabola, a key player in both the 1987 and 2000 overthrows, ${ }^{366}$ became High Commissioner to Papua New Guinea. Qarase also appointed Ratu Josefa Dimuri and Ratu Inoke Takiveikata, two high-ranking chiefs who supported the putsch, to the Senate. ${ }^{367}$ The actions of Qarase demonstrated his support for the nationalist chiefs. In addition to this, five members of Qarase's interim

\footnotetext{
364 Seniloli was Vie-President between March 2001 and November 2004. He was convicted of administering an unlawful oath and sentenced to four years in prison. Bhim, "The Impact of the Reconciliation, Tolerance and Unity Bill on the 2006 Election," pp. 118-19.

${ }^{365}$ Lal, "Heartbreak Islands: Reflections on Fiji in Transition," p. 338.

${ }^{366}$ Field, Baba, and Nabobo-Baba, Speight of Violence: Inside Fiji's 2000 Coup, p. 274.

367 Other notable appointments of Qarase's government with close association to the putsch include: Isikia Savua, Police Commissioner at the time of the 2000 coup, and allegedly involved in it, was appointed as Fiji's Permanent Representative to the United Nations and Adi Samanunu Talakuli, a known Speight supporter was appointed Fiji's High Commissioner to Malaysia. Lal, Islands of Turmoil: Elections and Politics in Fiji, p. 237.
} 
government, and then the following SDL-led government, were also subsequently convicted for assisting with the putsch. ${ }^{368}$

After a drawn-out process, the Director of Public Prosecutions announced in late 2004 that sufficient evidence had been compiled to launch prosecutions against those involved in the 2000 putsch. While several of the protagonists had been arrested following the release of the hostages, many chiefs who played key roles in the events remained free. The 2004 prosecutions produced a long list of convictions. ${ }^{369}$ Notable putschists convicted included: the putsch's leader, George Speight ${ }^{370}$ and the head of the CRWU, Colonel Ilisoni Ligari. ${ }^{371}$ A number of prominent high chiefs, who were members of Rabuka's SVT-led governments and Qarase's interim and elected governments, were also convicted. These included: paramount chief ${ }^{372}$ of Cakodrove and the Tovata confederacies and former SVT MP and minister in the SDL-led government, Ratu Naiqama Lalabalavu; ${ }^{373}$ paramount chief of Naitasiri, minister in Qarase's interim government, a senator and minister and in his SDL-led government, Ratu Inoke Takiveikata; ${ }^{374}$ former Fijian Association Party MP and minister in Qarase's interim government Ratu Timoci Silatolu; ${ }^{375}$ Senator and minister in the SDL-led government, Ratu Josefa Dimuri; ${ }^{376}$ and CAMV MP, Deputy Speaker of the House of Representatives in Qarase's government, Ratu Rakuita Vakalalabure. ${ }^{377}$ At the trials' conclusions, the state prosecutor made specific mention of the role played in the putsch by former SVT finance minister Berenado Vunibobo and NLTB General Manager Qarikau, though, both escaped conviction.

These convictions openly demonstrate the close connection between Fijis highest chiefs and the putsch, and that Qarase's appointment as interim Prime Minister and his subsequent cabinet appointments merely replaced an elected government with those who deposed it.

\footnotetext{
368 Bhim, "The Impact of the Reconciliation, Tolerance and Unity Bill on the 2006 Election," p. 118-19. 369 A total of 62 mutiny charges were laid and 24 treason charges against those accused of involvement in the putsch.

370 Convicted of treason and sentenced to life in prison

Bhim, "The Impact of the Reconciliation, Tolerance and Unity Bill on the 2006 Election," p. 118-19.

${ }^{371}$ Convicted of wrongful confinement and sentenced to two years in prison. Ibid.

372 Two (of the three) paramount chiefs were convicted of direct involvement with the putsch.

${ }^{373}$ Convicted of unlawful assembly and sentenced to eight months in prison Bhim, "The Impact of the Reconciliation, Tolerance and Unity Bill on the 2006 Election," p. 118-19.

${ }^{374}$ Convicted of inciting mutiny and sentenced to life in prison Ibid.

375 Convicted of treason an sentenced to life in prison Ibid.

${ }^{376}$ Convicted of unlawful assembly and sentenced to eight months in prison Ibid.

377 Convicted of administering an unlawful oath and sentenced to six years in prison Ibid.
} 
The convictions of the putschists did not eventuate until 2004, well after the return to electoral processes in 2001. After the putsch, Qarase's control of government as interim Prime Minister provided his newly formed SDL with a sense of political incumbency, which then translated to victory at the 2001 general election. In 2001, although electoral processes determined the composition of the lower house, Qarase's victory meant they merely legitimised the nationalist chiefs, many of whom were convicted in direct association with the 2000 putsch.

The events of the putsch itself and the political manoeuvring underlying the appointment of the 2000-2001 interim government, demonstrates the institutional structures underlying Fiji's political economy. Nationalist chiefs undertook the 2000 putsch to oust the Labourled government and replace it with a government that it controlled. The convictions of key protagonists of the putsch further demonstrated the clear connection between with the highest chiefs and the overthrow. ${ }^{378}$ The chiefs' actions were made possible by their position within the constitution and in prominent Pacific-Fijian political parties, and their material advantages over the rest of Fijian society. The putsch of 2000, as with the coup of 1987, expose a chiefly authoritarian elite, that has used whatever means necessary to defend itself against the electoral desires of the people. In fear of democratisation and the erosion of its material and social controls over Fiji, this elite repeatedly used authoritarian means to reinstate its grip over Fiji's political institutions.

Fiji's political institutions have never been democratic. Rather, its electoral institutions have provided a smokescreen behind which the authoritarian chiefly elite has manipulated government decision-making through the chiefly-backed Alliance, SVT and SDL parties, which have controlled government. When elections have resulted in the loss of control of government, the elite has summoned the necessary means to overthrow legitimately elected governments and reinstate a government of their design. The chiefly elite has only permitted electoral governance when the parties in government have supported its entrenched illiberal advantages.

\footnotetext{
378 The Qarase government's opposition to these convictions was evident in its presentation of the 2006 Promotion of Reconciliation, Tolerance and Unity Bill providing amnesty to those convicted in relation to the 2000 putsch. Ibid., pp. 111-43.
} 


\section{Chapter Six: Conclusion}

This thesis has argued that the repeated failings of Fiji's democratic system have been caused by the presence of an authoritarian political infrastructure, controlled by a chiefly elite, and maintained by Fiji's peculiar place in the world economy. This thesis has comprehensively examined the structure of this authoritarian infrastructure, the constitutional provisions that facilitate its operation as well its material foundations.

The final section of this thesis reflects on the important tenets of this research. First, it reiterates the post-colonial reality of Fiji's political institutions: a democratic façade controlled by an authoritarian chiefly elite. Second, it evaluates the present situation, where a military regime controls Fiji's government, and examines the prospects for democratisation after its eventual return to electoral rule. Finally, it projects the likely political future for Fiji, through an examination of the structures of its political and economic institutions, providing insight into the chances of long-term democratisation in Fiji.

This thesis initially posed four key questions to test the strength of its hypothesis. Revisiting these determines the how the tenets of the hypothesis been proven through the thesis. First it was posed, what institutional mechanisms have perpetuated chiefly hierarchy over Fijian society? Chapter Three demonstrated how the vesting of native land in chiefly control, the stipulated tiered distribution of lease rents to chiefs and the turaga's control of lease rents distribution have all perpetuated chiefs over Fijian society. While Chapters Four and Five demonstrated how chiefs material advantages over Fijian society have translated to political dominance.

The second question it asked concerned how Fiji's illiberal institutions been buffered from economic pressure on world markets. After examining the illiberal structures of Fijis landtenure system, this thesis has demonstrated how receipt of the EU's Sugar Protocol subsidies has permitted the maintenance of the land-tenure system. Chapter Three demonstrated how the excess earnings provided by these subsidises have enabled the chiefly controlled NLTB to charge highly inflated lease rents, which has inhibited efficient production and reinforced chiefly advantage over Fijian society. 
Finally, it was asked whether interruptions of Fijian democracy occurred when it has been at its weakest, or when they threatened to impinge on core chiefly institutions. Chapters Four and Five of this thesis has demonstrated how Fiji's history since independence shows one key theme: when non-chiefly-backed parties won government, they have been overthrown. Despite the presence of electoral institutions, authoritarian chiefly controlled institutions have reasserted themselves whenever their dominance was threatened. Fiji's history details the maintenance of authoritarianism as directed by high chiefs, to ensure the perpetuation of their controls over Fijian society.

This thesis has demonstrated the presence of authoritarian institutions underlying Fiji's polity, the source of these institutions, the means by which they have been perpetuated, and how they have usurped elected government repeatedly. It has demonstrated how Fiji's constitutional institutions have never been democratic, due to the control granted to the Council of Chiefs over policy reform of the land-tenure system. For the chiefly elite, this veto power was a safeguard and the linchpin of its control over Fijian society. The structure of the land-tenure system perpetuates chiefly authority over non-chiefs, Pacific-Fijian and Indo-Fijian alike. Despite the security of the veto, chiefs have acted to overthrow government after every change of government that has provided non-chiefly backed parties with the power to govern. This elite's monopoly control over land has enabled it to charge highly inflated rents set, not by equilibrium markets rates, but by the chiefs themselves. These advantages have been permitted in part through Fijis peculiar position in the world economy, as a recipient of the EU's Sugar Protocol subsidy.

Fiji's constitutional realities and underlying political-economic structure have plagued all attempts to forge a successful multicultural democracy. Under each of Fiji's constitutions, institutions were structured to ensure that the chiefly elite's dominance over Fijian society was maintained. These institutional provisions have provided a chiefly elite with formal controls and indirect means to subvert electoral outcomes when they threatened their authority. These coups as well as the solution to the 1977 'constitutional crisis', simply reinstated chiefly authority after chiefs lost direct control of government. 
2006 Coup

After a 'cold-war" ${ }^{379}$ between the SDL-led government and the Head of the RFMF, Commodore Voreqe Frank Bainimarama, elected government was again overthrown on 5 December 2006. Yet, this coup was undertaken for very different reasons and by protagonists with greatly different motivations to the previous two overthrows. This coup threw out a government that was most explicit in its advocacy for Pacific-Fijian rights, at the expense of others'. Since its electoral victory in 2001, the SDL-led government had sought to deepen institutional advantages given to Pacific-Fijians. This was best shown by various affirmative actions policies favouring Pacific-Fijians, and presentation of the Qoliqoli Bill, which would have privatised the foreshore and seabed in Fiji into chiefly control. In addition, it had released key protagonists of the 2000 military overthrow under the auspices of health concerns. This served to annul their wrong-doing in the minds of conservative Pacific-Fijians who had actively supported the putsch.

The initial actions of Bainimarama, including his sacking of the NLTB's Board of Trustees, have indicated his awareness of the chiefs' material controls over Fijian society. Bainimarama's actions have demonstrated his opposition to the monopoly the nationalist chiefs have held over political institutions, ever since he handed power to Qarase as the head of the interim government in the aftermath of the 2000 overthrow. However, this opposition is only to the nationalist chiefs controlling these institutions. Importantly a number of high chiefs are ministers in Bainimarama's interim government, including Ratu Epeli Ganilau and Ratu Epeli Nailatikau, who is now Vice-President. These chiefs portray themselves as 'moderates', and have been linked with Mara's faction since the 1990s. Since the 2006 coup there has been a visible split between the moderate and nationalist chiefs. Bainimarama has shown no desire whatsoever to dismantle high chiefs material advantages over Fijian society.

Due to the prolonged delays of Bainimarama's desired reforms, his true motivations for the coup are not clear, and it is difficult to determine whether he is a far-sighted statesman or short-sighted and self-interested one. Although Bainimarama's desired reform of the electoral system may neutralise ethnicity as a tool of political mobilisation, unless this is accompanied by reforms of the land-tenure system and chiefs' material advantages of

379 As described in Steven Ratuva, "The Pre-Election 'Cold War': The Role of the Fiji Military During the 2006 Election," in From Election to Coup: The 2006 Campaign and Its Aftermath, ed. Jon Fraenkel and Stewart Firth (Canberra: Asia Pacific Press, 2007), pp. 26-45. 
society it will not democratise Fiji's electoral institutions.

\section{Projections}

Irrespective of the actions of the Bainimarama regime, the EU's Sugar Protocol subsidy will cease to exist on 1 October $2009 .{ }^{380}$ In the short-term preferential payments are expected to continue, but at a decreased rate. There will be a, yet to be determined, timeperiod providing stepped decreases in subsidy payments from the Sugar Protocol's rate to world markets rates. ${ }^{381}$ The evaporation of excess earnings provided by the Sugar Protocol will produce a deep transformation of Fiji's political-economic structure.

Fiji's land-tenure system has never known the realities of free-market fluctuations and vulnerabilities. Fiji's sugar industry and its native land owners have always had the security of preferential prices, to sustain the illiberal structure of land tenures and distribution of rents: first as a British colony under the CSA and then after independence under the Sugar Protocol. As sugar export earnings drop either the FSC will collapse, halting all lease payments to land owners on behalf of lease holders, or farmers' earnings will drop to a level so low that most will be unable to continue farming sugar. Once either or these situations eventuate, either land-owning beneficiaries will see their rental income plummet, or the number of beneficiaries from that income must decrease sharply. Alternatively, if the number is not decreased, the legal state of the land may be reformed. Transfer to a liberal freehold land-tenure system seems unlikely, however, as it may provide opportunities for non-chiefly Fijians to gain a comparative edge in Fiji's political economy, something the monopoly over land and the illiberal distribution of rents has maintained for the chiefly elite alone.

The evaporation of this Sugar Protocol subsidy will also lead to further change is Fiji's demographic structure. As Indo-Fijian sugar leaseholders, namely those who have retained ALTA leases despite the non-renewal strategy of the NLTB, become increasingly unable to pay native land lease payments, large proportions will likely be forced to move into Fiji's urban centres, and in many cases its urban slums. There may also be an accelerated exodus of Indo-Fijians as they flee Fiji altogether to join family in Australia, Canada, New Zealand or the United States, as explained earlier.

380 The Council of the European Union, "Council Decision to Denounce the Acp Sugar Protocol."

381 A key theme of public EU documentation on the phase out of the Sugar Protocol displays its desire and perceived need to lessen the subsidy payment from a payment close to the CAP to one closer to the world market price. 
The prospects for democratisation in Fiji are slim. Under all of Fiji's constitutions, the Council of Chiefs has held effective veto power within the Senate over vital pieces of legislation. This demonstrates Fiji's political status as an authoritarian system, which has tolerated, at times, limited power sharing with electoral institutions. Each of Fiji's Constitutions have also entrenched the economic advantages first provided to the chiefly elite under colonial rule. Fiji's history with electoral institutions demonstrates that without structural reform of its authoritarian institutions, it is unlikely to produce any result that the repetition of authoritarian behaviour. Thus, for Fiji to become a democracy a complete transformation of its socio-political economic structures and the dismantling of chiefly controlled institutions are necessary. Most important to this is particularly the removal of the monopoly over the utilisation of native land, and the illiberal distribution of rental payments, from the control of the chiefly elite.

Given Fijiss history of political upheaval and the resulting lack of structural reform, it is unlikely that reform of its economic and political institutions will eventuate voluntarily. It is unlikely the Bainimarama regime, or any other chiefly influenced power wielder will reform the foundation of their material advantages, as they are aware it will erode their political and social dominance of Fijian society. As this thesis has demonstrated, it has not been domestic political forces that have determined the fundamental structures of Fiji's political economy. Rather, it has been its place in the world economy, determined at the outset by British colonial rule and maintained by EU subsidy payments. This reform, however, may eventuate unwillingly, irrespective of domestic political desires. With the evaporation of preferential payments to sustain its highly inefficient sugar industry, external material pressures may cause a total reworking of Fiji’s social and political order. 
Appendix 1: Raw sugar produced per sugar industry employee, selected developing countries

\begin{tabular}{|l|c|c|c|c|}
\hline & $\begin{array}{c}\text { Direct Employment } \\
\text { (growers and factory) }\end{array}$ & $\begin{array}{c}\text { Tones of Raw Sugar } \\
\text { Produced Average } \\
1999-2000\end{array}$ & $\begin{array}{c}\text { Tons of Raw Sugar } \\
\text { Per Employee }\end{array}$ & $\begin{array}{c}\text { EU Sugar } \\
\text { Protocol signatory }\end{array}$ \\
\hline $\begin{array}{l}\text { High Productivity } \\
\text { Producers }\end{array}$ & & $19,485,000$ & 17.7 & No \\
\hline Brazil & $1,100,000$ & 293,072 & 16.3 & Yes \\
\hline Guyana & 18,000 & $2,589,667$ & 19.9 & No \\
\hline South Africa & 130,000 & & & Yes \\
\hline $\begin{array}{l}\text { Low Productivity } \\
\text { Producers }\end{array}$ & & 336,333 & 8.3 & Periodically \\
\hline Fiji & 40,500 & 485,333 & 7.0 & Yes \\
\hline Kenya & 69,000 & 529,299 & 8.1 & Yes \\
\hline Mauritius & 65,000 & & & No \\
\hline Other Producers & & 200,667 & 11.8 & 16.9 \\
\hline Malawi & 17,000 & $5,069,233$ & & \\
\hline Mexico & 300,000 & & & \\
\hline
\end{tabular}

Source: Donald Mitchell, 'Sugar Policies: Opportunities for Change, Development Prospects Group,' in Global Agricultural Trade and Developing Countries, ed. M. Ataman Aksoy and John C. Beghin (Washington DC: The International Bank for Reconstruction and Development / The World Bank, 2005), p. 145. 
Appendix 2: Expiry numbers of ALTA sugarcane leases held by Indo-Fijians due to expire in Fiji 1997-2024

\begin{tabular}{|c|c|}
\hline Year of expiry & $\begin{array}{c}\text { Indo-Fijian expiring ALTA } \\
\text { sugarcane leases }\end{array}$ \\
\hline 1997 & 27 \\
\hline 1998 & 120 \\
\hline 1999 & 158 \\
\hline 2000 & 1,133 \\
\hline 2001 & 1,494 \\
\hline 2002 & 310 \\
\hline 2003 & 435 \\
\hline 2004 & 216 \\
\hline 2005 & 228 \\
\hline 2006 & 301 \\
\hline 2007 & 415 \\
\hline 2008 & 255 \\
\hline 2009 & 204 \\
\hline & Averages listed below \\
\hline $2010-14$ & 199 \\
\hline $2015-24$ & 45 \\
\hline Total & 6,743 \\
\hline
\end{tabular}

Source: Mahendra Reddy and Vijay Naidu, "Land Tenure System in Fiji: The Poverty Implications of Expiring Leases," Development Bulletin 55 (2001), p. 34. 


\section{Bibliography}

Agricultural Landlord and Tenant Act 1976.

Ali, Ahmed. "The Fiji General Election of 1977." The Journal of Pacific History 12, no. Part 4 (1977): 189-201.

Alley, Roderic. "Fiji's Coups of 1987 and 2000: A Comparison." Revue Juridique Polynesienne 1, (2001): 217-39.

. "The Emergence of Party Politics in Fiji." In Politics in Fiji: Studies in Contemporary History, edited by Brij V. Lal. North Sydney, New South Wales: Allen \& Unwin, 1986.

Bavadra, Timoci. "Text Address by the Newly Elected President of the Fiji Labour Party." In Fiji Labour Party 1st Annual Conference. Suva: South Pacific Forum, 1986.

Bayliss-Smith, Tim, Richard Bedford, Harold Brookfield, and Marc Latham. Islands, Islanders and the World: The Colonial and Post-Colonial of Eastern Fiji, Cambridge Human Geography. Cambridge: Cambridge University Press, 1988.

Bhim, Mosmi. "The Impact of the Reconciliation, Tolerance and Unity Bill on the 2006 Election." In From Election to Coup: The 2006 Campaign and Its Aftermath, edited by Jon Fraenkel and Stewart Firth. Canberra: Asia Pacific Press, 2007.

Bole, Filipe N. "Fiji's Chiefly System and Its Pattern of Political Self-Reliance." In Culture and Democracy in the South Pacific, edited by Ron Crocombe, Uentabo Neemia, Asesela Ravuvu and Werner Vom Busch, 66-79. Suva: Institute of Pacific Studies, University of the South Pacific, 1992.

Bureau, J. C., H. Guyomard, and V. Requillart. "Inefficiencies in the European Sugar Regime." Journal of Policy Modeling 23, no. 6 (2001): 659-67.

Chaudhry, Mahendra. The Rise of the Fijian Labour Party. Sydney: H. V. Evatt Memorial Foundation, 1987.

Cole, Rodney V., Stephen I. Levine, and Anare V. Matahau. "The Fijian Provincial Administration." Honolulu: Pacific Islands Development Program, East-West Center, 1984.

Collier, David, and Stephen Levitsky. "Democracy with Adjectives: Conceptual Innovation in Comparative Research." World Politics 49, no. 3 (1997): 430-51.

Colonial Office of Fiji. "Legislative Council Paper No. 27 of 1914." 1914.

Constitution of the Republic of the Fiji Islands 1997. Act No. 13 of 1997 as amended by Act No. 5 of 1998.

Constitution of the Republic of the Fiji Islands 1997. Act No. 13 of 1997 as amended by Act No. 5 of 1998.

Constitution of the Sovereign Democratic Republic of Fiji 1990.

Dahl, Robert A. After the Revolution? Authority in a Good Society. New Haven and London: Yale University Press, 1970.

. Polyarchy: Participation and Opposition. New Haven and London: Yale University Press, 1971.

Dean, Eddie, and Stan Ritova. Rabuka: No Other Way. Moorebank, New South Wales: Doubleday, 1988.

Denning, Lord. "The Award of the Rt. Hon. Lord Denning in the Fiji Sugar Cane Contract Dispute 1969." Suva: The Government of Fiji, 1970.

Devi Singh, Ronita, and Mahendra Reddy. "Corporate Governance in Fiji's Native Land Trust Board." Pacific Economic Bulletin 22, no. 2 (2007): 36-52.

Driti, Pita. "Pacific News." Morning Report, Radio New Zealand National, 3 April 2009.

Durutalo, Alumita. "Elections and the Dilemma of Indigenous Fijian Political Unity." In Fiji before the Storm: Elections and the Politics of Development, edited by Brij V. Lal. 
Canberra: Asia Pacific Press, Southwood Press Pty Limited, 2000.

Durutalo, Simione. "Na Lotu, $\mathrm{Na}$ Vanua, $\mathrm{Na}$ Mataintu/the Church, Tradition and the State: The Paramountcy of Fijian Interest and the Polarisation of Ethnicity." In South

Pacific Forum Working Paper no. 6. Suva: Sociology Society, School of Social \& Economic Development, University of the South Pacific, 1986.

. "The Fiji Trade Union Movement at the Crossroads: Social and Political Options

for the Labour Movement." In Fiji Trade Union Council Workshop on Social and Political Options for the Labour Movement in Fiji. Suva, 1985.

Durutalo, Simione, and Epeli Hau'ofa. "Tonga's Pro-Democracy Movement: An Interview between Simione Durutalo and Professor Epeli Hau'ofa." Review 20, (1993): 1-102. European Commission. "A Description of the Common Market Organisation of the Market in Sugar - Acp Protocol/Agreement with India - Annex Iii." Brussels: European Commission, 2004.

. "Eu-Acp Trade Main Products Imported 2003, Acp Statistical Analysis."

European Commission, 2003.

. "The European Sugar Sector: A Long-Term Competitive Future." Brussels:

European Commission, 2006.

Field, Michael, Tupeni Baba, and Unaisi Nabobo-Baba. Speight of Violence: Inside Fiji's 2000 Coup. Auckland: Reed Publishing, 2005.

Fiji 1970 Constitution.

Fiji Sugar Corporation. "The Fiji Sugar Industry." Fijian Studies 1, no. 2 (2003): 315-26.

Fisk, E. H. The Political Economy of Independent Fiji. Wellington and Auckland: A. H. \& A. W. Reed, 1970.

Fison, Lorimer. Land Tenure in Fiji. London: Harrison, 1881.

Fraenkel, Jon. "The Alternative Vote System in Fiji: Electoral Engineering or BallotRigging?" Journal of Commonwealth and Comparative Politics 39, no. 1 (2001): 1-31. . "The Clash of Dynasties and Rise of Demagogues; Fiji's Tauri Vakaukauwa of May 2000." The Journal of Pacific History 35, no. 3 (2000): 295-308.

. "The Failure of Electoral Engineering in Fiji." Peace Initiatives 6, no. 1-3 (2000): 103-08.

. "The Triumph of Non-Idealist Intellectuals? An Investigation of Fiji's 1999 Election Results." Australian Journal of Politics and History 46, no. 1 (2000): 86-109.

Fraenkel, Jon, and Bernard B. Grofman. "A Neo-Downsian Model of the Alternative Vote as a Mechanism for Mitigating Conflict in Plural Societies." Public Choice 121, (2004): 487-506.

. "Does the Alternative Vote Foster Moderation in Ethnically Divided Societies? The Case of Fiji." Comparative Political Studies 39, no. 5 (2006): 623-51.

. "The Failure of Alternative Vote as a Tool for Ethnic Moderation in Fiji: A Rejoinder to Horowitz." Comparative Political Studies 39, no. 5 (2006): 663-66.

France, Peter. The Charter of Land: Custom and Colonization in Fiji Melbourne: Oxford University Press, 1969.

Gerschenkron, Alexander. Bread and Democracy in Germany. New York: Cornell University Press, 1989.

Ghai, Yash, and Jill Cottrel. "A Tale of Three Constitutions: Ethnicity and Politics in Fiji." $I \bullet$ CON 5, no. 4 (2007): 639-69.

- Heads of State in the Pacific: A Legal and Constitutional Analysis. Suva: Institute of Pacific Studies of the University of the South Pacific, 1990.

Gounder, Christene. "Journalists and the George Speight Coup." Pacific Journalism Review 13, no. 1 (2007).

Gourevtich, Peter. "International Trade, Domestic Coalitions, and Liberty: Comparative Responses to the Crisis of 1973-1896." Journal of Interdisciplinary History 8, no. 2 
(1977): 281-313.

. Politics in Hard Times: Comparative Responses to International Economic Crises. Edited by Peter J. Katzenstein, Cornell Studies in Political Economy. Ithaca and London: Cornell University Press, 1986.

. "The Second Image Reversed: The International Sources of Domestic Politics." International Organization 32, no. 4 (1978): 881-912.

Hewitt, Adrian P. "Guyana, Sugar and Eba: Case-Study of a Country Which Is Not Quite Least Developed." In The Regulatory Framework of Globalisation Barcelona, Spain: Overseas Development Institute, London, 2001.

Hines, Ruth D. "Financial Accounting: In Communicating Reality, We Construct Reality." Accounting Organizations and Society 13, no. 3 (1988): 251-61.

Horowitz, Donald L. "Encouraging Electoral Accommodation in Divided Societies." In Electoral Systems in Divided Societies: The Fiji Constitution Review, edited by Brij V. Lal and P. Larmour, 21-37. Canberra: The Australian National University Press, 1997. . "Strategy Takes a Holiday: Fraenkel and Grofman on the Alternative Vote." Comparative Political Studies 39, no. 5 (2006): 652-62.

. "The Alternative Vote and Interethnic Moderation: A Reply to Fraenkel and Grofman." Public Choice 121, (2004): 507-16.

Howard, Michael C. Fiji: Race and Politics in an Island State. Vancouver: University of British Columbia Press, 1991.

. "Vanuatu: The Myth of Melanesian Socialism." Labour, Capital and Society 16, no. 2 (1983): 176-203.

Huntington, Samuel P. The Third Wave: Democratization in the Late Twentieth Century.

Oklahoma: University of Oklahoma Press, 1993.

Kelsey, Jane. "A People's Guide to the Pacific Economic Partnership Agreement.

Negotiations between the Pacific Islands and the European Union Pursuant to the

Cotonou Agreement 2000." In World Council of Churches. Suva, 2005.

Krueger, Anne O. . "The Political Economy of the Rent-Seeking Society." The American Economic Review 64, no. 3 (1974): 291-303.

Lal, Brij V. "Before the Storm: An Analysis of the Fiji General Election of 1987 " Pacific Studies 12, no. 1 (1988): 71-96.

Broken Waves: A History of the Fiji Islands in the Twentieth Century, Pacific Islands Monograph Series Honolulu: University of Hawaii Press, 1992.

. "'Chiefs and Thieves and Other People Besides': The Making of George Speight's Coup." The Journal of Pacific History 35, no. 3 (2000): 281-93.

. "Heartbreak Islands: Reflections on Fiji in Transition." Asia Pacific Viewpoint 44, no. 3 (2003): 335-50.

. Islands of Turmoil: Elections and Politics in Fiji. Canberra: Asia Pacific Press 2006. . "Postscript: The Emergence of the Fiji Labour Party." In Politics in Fiji: Studies in Contemporary History, edited by Brij V. Lal, 139-57. North Sydney, New South Wales: Allen \& Unwin, 1986.

. Power and Prejudice: The Making of the Fiji Crisis. Wellington: New Zealand Institute of International Affairs, 1988.

. "Rhetoric and Reality: The Dilemmas of Contemporary Fijian Politics." In Culture and Democracy in the South Pacific, edited by Ron Crocombe, Uentabo Neemia, Asesela Ravuvu and Werner Vom Busch, 97-116. Suva: Institute of Pacific Studies, University of the South Pacific, 1992.

Lal, P., H. Lim-Applegate, and M. Reddy. "Alta or Nlta: What's in a Name? Land Tenure Dilemma and the Fiji Sugar Industry." In Working Paper No. 46, October 2001: Land-

Tenure Center, University of Wisconsin-Madison, 2001.

Lands Department. "Agricultural Landlord and Tenant Act (Chapter 270) - Agricultural 
Land (Declaration of Unimproved Capital Values) Order - 1987, Legal Notice No. 67 of 1987." Suva: Fiji Government Printer, 1987.

. "Agricultural Landlord and Tenant Act (Chapter 270) - Agricultural Land

(Declaration of Unimproved Capital Values) Order - 1992, Legal Notice No. 127 of 1992." Suva: Fiji Government Printer, 1992.

. "Agricultural Landlord and Tenant Act (Chapter 270) - Agricultural Land

(Declaration of Unimproved Capital Values) Order - 1997, Legal Notice No. 104 of 1997." Suva: Fiji Government Printer, 1997.

Lawson, Stephanie. The Failure of Democratic Politics in Fiji. Oxford: Claredon Press; Oxford University Press, 1991.

. Tradition Versus Democracy in the South Pacific: Fiji, Tonga and Western Samoa.

Cambridge: Cambridge University Press, 1996.

Levitsky, Stephen, and Lucan A. Way. "The Rise of Competitive Authoritarianism." Journal of Democracy 13, no. 2 (2002): 51-65.

Lipset, Seymour Martin. Political Man: The Social Bases of Politics. Expanded and Updated edition ed. Baltimore, Maryland: John Hopkins Universtiy Press, 1981.

. "The Social Requisites of Democracy Revisited: 1993 Presidential Address."

American Sociological Review 59, no. 1 (1994): 1-22.

Majesky, Olivia. "Metric of the Month: Salaries as a Percentage of Operating Expense." Society for Human Resource Management Research Quarterly 8-9, (2008).

Mara, Kaimesese. The Pacific Way: A Memoir. Honolulu: University of Hawaii Press, 1997.

Mitchell, Donald. "Sugar Policies: Opportunities for Change, Development Prospects Group." In Global Agricultural Trade and Developing Countries, edited by M. Ataman Aksoy and John C. Beghin. Washington DC: The International Bank for Reconstruction and Development / The World Bank, 2005.

. "Sugar Policies: Opportunity for Change." In World Bank Policy Research Working Paper 3222: Development Prospect Group, The World Bank, 2004.

Moore, Barrington, Jnr. Social Origins of Dictatorship and Democracy: Lord and Peasent in the Making of the Modern World. Boston: Beacon Press, 1966.

Morgan, Gareth. "Accounting as Reality Construction: Towards a New Epistemology for

Accounting Practice." Accounting Organizations and Society 13, no. 5 (1988): 477-85.

Narayan, Jay. The Political Economy of Fiji. Suva: South Pacific Review Press, 1984.

Narayan, Paresh Kumar, and Biman C. Prasad. "Economic Importance of the Sugar Industry in Fiji: Stimulating the Impact of a 30\% Decline in Sugar Production." In Working Paper No. 2004/12, July 2004 Suva: Department of Economics, University of the South Pacific, 2004.

. "Fiji's Sugar, Tourism and Garment Industries: A Survey of Performance, Problems and Potentials " Fijian Studies 1, no. 1 (2003).

Native Land Trust Act 1970. Legal Notice 112 of 1970.

Native Land Trust Board. "Distinctions between Native Land Trust Act \& Agricultural Landlord and Tenant Act." Native Land Trust Board.

. "Frequently Asked Questions."

. "Investing."

. "Native Land Trust Board Annual Report 1990-1997." Suva: Native Land Trust Board, 1998.

. "Native Land Trust Board Annual Report 1998." Suva: Native Land Trust Board, 1998.

. "Native Land Trust Board Annual Report 1999." Suva: Native Land Trust Board, 2000.

. "Native Land Trust Board Annual Report 2000." Suva: Native Land Trust Board, 2001. 
. "Native Land Trust Board Annual Report 2001." Suva: Native Land Trust Board, 2002.

. "Native Land Trust Board Annual Report 2002." Suva: Native Land Trust Board, 2002.

. "Native Land Trust Board Annual Report 2003." Suva: Native Land Trust Board, 2003.

. "Native Land Trust Board Annual Report 2004." Suva: Native Land Trust Board, 2005.

. "Native Land Trust Board Website." http://www.nltb.com.fi.

. "Ownership Structure."

"Vanua: Native Land Trust Board Annual Report 1976." Suva: Native Land Trust Board, 1977.

. "Vanua: Native Land Trust Board Annual Report 1977." Suva: Native Land Trust Board, 1978.

. "Vanua: Native Land Trust Board Annual Report 1978." Suva: Native Land Trust Board, 1979.

. "Vanua: Native Land Trust Board Annual Report 1979." Suva: Native Land Trust Board, 1980.

. "Vanua: Native Land Trust Board Annual Report 1980." Suva: Native Land Trust Board, 1981.

. "Vanua: Native Land Trust Board Annual Report 1981." Suva: Native Land Trust Board, 1982.

. "Vanua: Native Land Trust Board Annual Report 1982." Suva: Native Land Trust Board, 1983.

. "Vanua: Native Land Trust Board Annual Report 1983." Suva: Native Land Trust Board, 1984.

. "Vanua: Native Land Trust Board Annual Report 1984." Suva: Native Land Trust Board, 1985.

. "Vanua: Native Land Trust Board Annual Report 1985." Suva: Native Land Trust Board, 1987.

. "Vanua: Native Land Trust Board Annual Report 1986." Suva: Native Land Trust Board, 1988.

. "Vanua: Native Land Trust Board Annual Report 1987." Suva: Native Land Trust Board, 1989.

. "Vanua: Native Land Trust Board Annual Report 1988." Suva: Native Land Trust Board, 1991.

. "Vanua: Native Land Trust Board Annual Report 1989." Suva: Native Land Trust Board, 1991.

. "Vanua: Native Land Trust Board Review 1969-1974 ". Suva: Native Land Trust Board, 1974.

Native Land Trust Ordinance 1940.

Native Lands Act 1905.

Native Lands Ordinance 1875.

Nayacakalou, Rusiate R. Leadership in Fiji. Melbourne: Oxford University Press, 1975.

Norton, Robert. Race and Politics in Fiji. 1st ed. St Lucia and New York: University of Queensland Press and St Martin's Press, 1977.

. Race and Politics in Fiji. 2nd ed. St Lucia: University of Queensland Press, 1990.
.The Great Council of Chiefs in Fiji's Era of Crisis and Reform." In 1987: Fiji

Twenty Years On, edited by Brij V. Lal, Ganesh Chand and Vijay Naidu, 113-32.

Lautoka: Fiji Institute of Applied Studies, 2008.

Osman, Wali M. "Fiji: Economic Report, September 1998 ". Honolulu: Bank of Hawaii, 
1998.

Polanyi, Karl. The Great Transformation: The Political and Economic Origins of Our Time. Boston: Beacon Press, 1957.

Prasad, Biman C. "Property Rights, Economic Performance and the Environment in Fiji: A Study Focusing on Sugar, Tourism and Forestry - Unpublished Ph.D Dissertation." University of Queensland, 1998.

Prasad, Biman C., and Paresh Kumar Narayan. "Fiji Sugar Corporation's Profitability and Sugar Cane Production: An Econometric Investigation, 1972-2000." In USPEC Working Paper. Suva: USPEC, Department of Economics, University of the South Pacific, 2003.

Premdas, Ralph. "General Rabuka and the Fijian Elections of 1992." Asian Survey 33, no. 10 (1993): 997-1009.

Przeworksi, Adam. Democracy and the Market: Political and Economic Reforms in Eastern Europe and Latin America. Edited by Jon Elster and Michael S. McPherson, Studies in Rationality and Social Change. Cambridge: Cambridge University Press, 1991.

Rabuka, Sitiveni L. "The Fiji Islands in Transition: Personal Reflections." In Fiji before the Storm: Elections and the Politics of Development, edited by Brij V. Lal. Canberra: Asia Pacific Press, Southwood Press Pty Limited, 2000.

Ratuva, Steven. "The Pre-Election 'Cold War': The Role of the Fiji Military During the 2006 Election." In From Election to Coup: The 2006 Campaign and Its Aftermath, edited by Jon Fraenkel and Stewart Firth. Canberra: Asia Pacific Press, 2007.

Ravuvu, Asesela. "Culture and Traditions: Implications for Modern Nation Building." In Culture and Democracy in the South Pacific, edited by Ron Crocombe, Uentabo Neemia, Asesela Ravuvu and Werner Vom Busch, 56-65. Suva: Institute of Pacific Studies, University of the South Pacific, 1992.

- The Facade of Democracy: Fijian Struggles for Political Control 1830-1987. Suva: Reader Publishing House, 1991.

. "The Fijian Chiefly System and the Democratic Process." Suva: Pacific Cultural Programme, 1991.

. Vaka I Taukei: The Fijian Way of Life. Suva: Institute of Pacific Studies, University of the South Pacific, 1983.

Reddy, Mahendra. "Implication of Tenancy Status on Productivity and Efficiency: Evidence from Fiji." Sri Lankan Journal of Agricultural Economics 4, no. 1 (2002): 1937.

. "Production Analysis of Fiji's Sugar Industry. Unpublished Ph.D Dissertation." University of Hawaii, 1998.

Reeves, Paul, Tomasi Rayalu Vakatora, and Brij V. Lal. "The Fiji Islands : Towards a United Future. Report of the Fiji Constitution Review Commission 1996." In Parliamentary Paper No. 34 of 1996, edited by Parliament of Fiji. Suva: Parliament of Fiji, 1996.

Robertson, Robert T., and William Sutherland. Government by the Gun: The Unfinished Business of Fiji's 2000 Coup. Annaadale, New South Wales: Pluto Press, 2001.

Robertson, Robert T., and Akosita Tamanisau. Fiji: Shattered Coups. Leichhardt, New South Wales: Pluto Press 1988.

Rogowski, Ronald. Commerce and Coalitions: How Trade Affects Domestic Political Alignments. Princeton, New Jersey: Princeton University Press, 1989.

. "Trade and Variety of Democratic Institutions." International Organization 41, no. 2 (1987): 203-23.

Scarr, Deryck. Fiji: A Short History. Hawaii: The Institute for Polynesian Studies, 1984.

. Fiji: Politics of Illusion, the Military Coups in Fiji Kensington, New South Wales: New South Wales University Press, 1988.

—. Ratu Sukuna: Soldier, Statesman, Man of Two Worlds. London and Basingstoke: 
Macmilliam Education Limited, 1980.

Schumpeter, Joseph A. Capitalism, Socialism and Democracy. 2nd ed. New York and London: Harper \& Brothers Publishers, 1942.

Sharpham, John. Rabuka of Fiji: The Authorised Biography of Major-General Sitiveni Rabuka. Rockhampton, Queensland: Central Queensland University Press, 2000.

Spate, O. H. K. . "The Fijian People: Economic Problems and Prospects." edited by Legislative Council of Fiji. Suva: Colony of Fiji Government Press, 1959.

Sugar Industry Tribunal. "Sugar Industry Tribunal Master Award." Suva: Sugar Industry Tribunal, 1997.

Sutherland, William. Beyond the Politics of Race: An Alternative History of Fiji to 1992, Political and Social Change Monograph 15. Canberra: Department of Political and Social Change, Research School of Pacific Studies, Australian National University, 1992.

Taagepera, Rein. "How Electoral Systems Matter for Democratization." Democratization 5, no. 3 (1998): 68-91.

Tagupa, William E. H. "The 1987 Westminster Constitutional Crisis in Fiji." Pacific Studies 12, no. 1 (1988): 97-151.

Teaiwa, Teresia. "An Analysis of the Political Crisis in Fiji." Scoop Media, 23 May 2000.

The Colonial Sugar Refining Company Limited. "Lord Denning's Award Concerning the Fiji Sugar Cane Contract: Observations on Its Consequences and Mistakes." Sydney: The Colonial Sugar Refining Company Limited, 1970.

The Council of the European Union. "Council Decision to Denounce the Acp Sugar Protocol." Brussels: The Council of the European Union, 2007.

Tullock, Gordon. "The Costs of Special Privilege." In Perspectives on Positive Political Economy, edited by James E. Alt and Kenneth A. Shepsle. New York: Cambridge University Press, 1990.

. "The Welfare Cost of Tariffs, Monopolies and Theft." Western Economic Journal 5, (1967): 224-32.

Wallerstein, Immanuel. The Modern World-System: Capitalist Agriculture and the Origins of the European World-Economy in the Sixteenth Century. Edited by Charles Tilly, Studies in Social Discontinuity. New York: Academic Press, 1974.

. "The Rise and Future Demise of the World Capitalist System: Concepts for

Comparative Analysis." Comparative Studies in Social History 16, no. 4 (1974): 387-415.

Williams, George. "The Case That Stopped a Coup? The Rule of Law and Constitutionalism in Fiji." Oxford University Commonwealth Law Journal 73, no. 1 (2001): 73-94.

Zakaria, Fareed. "The Rise of Illiberal Democracy." Foreign Affairs 76, no. 6 (1997): 22-43. 